\title{
Tumor cell-extracellular matrix interactions : studies with antibodies to basement membrane components
}

Citation for published version (APA):

Havenith, M. G. (1988). Tumor cell-extracellular matrix interactions : studies with antibodies to basement membrane components. [Doctoral Thesis, Maastricht University]. Rijksuniversiteit Limburg. https://doi.org/10.26481/dis.19880624mh

Document status and date:

Published: 01/01/1988

DOI:

10.26481/dis.19880624mh

Document Version:

Publisher's PDF, also known as Version of record

\section{Please check the document version of this publication:}

- A submitted manuscript is the version of the article upon submission and before peer-review. There can be important differences between the submitted version and the official published version of record.

People interested in the research are advised to contact the author for the final version of the publication, or visit the DOI to the publisher's website.

- The final author version and the galley proof are versions of the publication after peer review.

- The final published version features the final layout of the paper including the volume, issue and page numbers.

Link to publication

\footnotetext{
General rights rights.

- You may freely distribute the URL identifying the publication in the public portal. please follow below link for the End User Agreement:

www.umlib.nl/taverne-license

Take down policy

If you believe that this document breaches copyright please contact us at:

repository@maastrichtuniversity.nl

providing details and we will investigate your claim.
}

Copyright and moral rights for the publications made accessible in the public portal are retained by the authors and/or other copyright owners and it is a condition of accessing publications that users recognise and abide by the legal requirements associated with these

- Users may download and print one copy of any publication from the public portal for the purpose of private study or research.

- You may not further distribute the material or use it for any profit-making activity or commercial gain

If the publication is distributed under the terms of Article $25 \mathrm{fa}$ of the Dutch Copyright Act, indicated by the "Taverne" license above, 
TUMOR CELL-EXTRACELLULAR MATRIX INTERACTIONS:

STUDIES WITH ANTIBODIES TO BASEMENT MEMBRANE COMPONENTS 
Druk: Groenevelt b.v., Landgraaf 


\title{
TUMOR CELL-EXTRACELLULAR MATRIX INTERACTIONS: STUDIES WITH ANTIBODIES TO BASEMENT MEMBRANE COMPONENTS
}

\author{
PROEFSCHRIFT
}

ter verkrijging van de graad van doctor aan de Rijksuniversiteit Limburg te Maastricht, op gezag van de Rector Magnificus, prof.dr. F.I.M. Bonke, volgens het besluit van het College van Dekanen, in het openbaar te verdedigen op vrijdag, 24 juni 1988 om 16.00 uur

door

Michaël Gerardus Havenith geboren te Kerkrade in 1950 
promotor:

prof.dr. F.T. Bosman

beoordelinsgscommissie: prof.dr. G. Kootstra

prof.dr. G.H. Blijham

prof.dr. J.P.M. Geraedts

prof.dr. M. Mareel

prof.dr. A. Martinez-Hernandez 
voor Marlie 


\section{CONTENTS}

chapter 1 General Introduction 11

1.1 Introduction 1I

$1.2 \quad$ Basement membrane structure 11

$\begin{array}{lll}1.3 & \text { Basement membrane composition } & 12\end{array}$

$1.4 \quad$ Cell-binding to basement membranes 15

$\begin{array}{lll}1.5 & \text { Basement membranes in cancer } & 15\end{array}$

$\begin{array}{lll}\text { 1.5.1 Basement membrames and invasion } & 15\end{array}$

$\begin{array}{ll}\text { 1.5.2 } & \begin{array}{l}\text { Basement membrane components as markers of } \\ \text { cellular differentiation }\end{array}\end{array}$

$\begin{array}{lll}1.6 & \text { Aim of the study } & 20\end{array}$

$\begin{array}{lll}1.6 & \text { References } & 21\end{array}$

chapter 2 Human specific anti type IV collagen monoclonal antibodies, characterization and immunohistochemical $\begin{array}{ll}\text { application } & 27\end{array}$

$\begin{array}{lll}2.1 & \text { Introduction } & 27\end{array}$

$\begin{array}{lll}2.2 & \text { Material and methods } & 28\end{array}$

$\begin{array}{lll}2.2 .1 & \text { Isolation and characterization of collagens } & 28\end{array}$

2.2.2 Preparation and isolation of hybridomas 29

2.2.3 Preparation of polyclonal antiserum 29

$\begin{array}{ll}2.2 .4 & \text { Immunological characterization }\end{array}$

$\begin{array}{lll}2.2 .5 & \text { Tissues } & 30\end{array}$

2.2.6 Enzymes 30

$\begin{array}{lll}2.2 .7 & \text { Immunohistochemistry } & 30\end{array}$

2.3 Results 3!

2.3.1 Polyclonal antiserum 31

2.3.2 Monoclonal antibodies 32

$\begin{array}{lll}2.3 .3 & \text { Species and organ specificity } & 35\end{array}$

2.4 Discussion 35

$\begin{array}{lll}2.5 & \text { References } & 37\end{array}$

chapter 3 Origin of basement membrane type IV collagen in xenografted human epithelial tumor cell-lines 39

$\begin{array}{lll}3.1 & 39\end{array}$

3.2 Material and methods 39

3.2.1 Tissues 39 
3.3.2 Type IV collagen labelling in primary colonic

chapter 4 Type IV collagen immunoreactivity in colorectal cancer:

Prognostic value of basement membrane deposition 51

$\begin{array}{lll}4.1 & 51\end{array}$

4.2 Material and methods 51

4.2.1 Case material 53

4.2.2 Immunohistochemistry 53

4.2.3 Statistical analysis $\quad 55$

$4.3 \quad$ Results 55

4.3.1 Immunohistochemistry 55

4.3.2 Clinicopathological data 55

4.4 Discussion $\quad 56$

$\begin{array}{lll}4.5 & \text { References } & 57\end{array}$

chapter 5 Basement membranes in bronchogenic squamous cell carcinoma: An immunohistochemical and ultrastructural study.

$5.1 \quad$ Introduction $\quad 59$

$\begin{array}{lll}5.2 & \text { Material and methods } & 60\end{array}$

$\begin{array}{lll}5.2 .1 & 60\end{array}$

5.2.2 Antibodies $\quad 62$

$\begin{array}{lll}5.2 .3 & \text { Immunohistochemistry } & 62\end{array}$

5.3 Results 64

5.4 Discussion 71

$\begin{array}{lll}5.5 & \text { References } & 73\end{array}$

chapter 6 Basement membrane deposition in benign and malignant nevo-melanocytic lesions: An immunohistochemical study with antibodies to basement membrane components 75

$\begin{array}{lll}6.1 & 75\end{array}$

6.2 Material and methods $\quad 76$

$\begin{array}{lll}\text { 6.2.1 Case material } & 76\end{array}$ 
6.3.1 Immunohistochemistry 77

$\begin{array}{lll}\text { 6.3.2 Benign nevus cell tumors } & 79\end{array}$

6.3.3 Malignant melanoma with an adjacent component 81

6.3.4 Additional findings in mallignant melanomas 81

$\begin{array}{lll}6.4 & \text { Discussion } & 82\end{array}$

6.5. References 84

$\begin{array}{lll}\text { chapter } 7 & \text { General Discussion } & 87\end{array}$

$\begin{array}{lll}7.1 & \text { Introduction } & 87\end{array}$

7.2 Basement membrane structure and composition $\quad 87$

7.3 Basement membrane deposition in neoplasia 88

$\begin{array}{lll}7.4 & \text { Basement membrane and tumor invasion } & 88\end{array}$

7.5 Basement membrane immunostaining in diagnostic histopathology $\quad 89$

$\begin{array}{ll}7.6 & \text { Concluding remarks }\end{array}$

$\begin{array}{lll}7.7 & \text { References } & 91\end{array}$

$\begin{array}{lr}\text { Summary } & 93\end{array}$

$\begin{array}{lr}\text { Samenvatting } & 97\end{array}$

$\begin{array}{ll}\text { Dankwoord } & 101\end{array}$

$\begin{array}{ll}\text { Curriculum vitae } & 103\end{array}$ 



\section{CHAPTER 1}

\section{General Introduction *}

\subsection{INTRODUCTION}

Basement membranes (BM) occur almost everywhere in the body. They are found where epithelial cells border mesenchymal stroma. They connect vascular endothelium with the surrounding matriceal and cellular components of the vessel wall. They surround individual fat cells, Schwann cells, smooth muscle cells and cross striated muscle fibers and separate mesothelial cells from the adjacent connective tissue (1). Several functions are ascribed to BM. In structures such as nerves and in smooth, skeletal and cardiac muscle they provide strong but flexible physical support. In parenchymatous organs they serve as a scaffold for the epithelial cells (2-4). Furthermore they modulate the differentiation of epithelial cells, which is of particular importance during embryonal development (5). In the kidney they function as a semipermeable filtration barrier $(6,7)$.

In recent years many investigators have studied BM in a variety of neoplasms. Most studies have concerned the structural alterations in the BM in relation to infiltrative growth. It has been shown that in most carcinomas BM are fragmented and penetrated by invasive neoplastic epithelial cells (8). This phenomenon is of interest for at least two reasons. Firstly, knowledge of the mechanisms which lead to BM disintegration during invasive growth might shed some new light on the aberrant behavior of invasive neoplastic cells. Secondly, absence or fragmentation of the BM may be a useful criterium to distinguish between benign or in situ malignant and invasive neoplasms. In this review we will briefly discuss the structure and composition of $\mathrm{BM}$, and provide a comprehensive overview of the current knowledge of BM alterations in neoplasia.

\subsection{BASEMENT MEMBRANE STRUCTURE}

The nomenclature concerning the BM is somewhat inconsistent in the literature. For practical purposes in this thesis we will use the term BM as synonymous with basal lamina, which in most $\mathrm{BM}$ is a combination of a lamina rara (lucida) and a lamina densa. By light microscopy BM, which can be more or less selectively stained by the PAS method or silver impregnation techniques, $(9,10)$ appear as thin structures

* Based on:

Basement membranes in cancer

Bosman FT, Havenith MG, Cleutjens JPM

Ultrastructural Pathology 1985; 8: 29\|-304 
separating the cells from the adjacent connective tissue. By electron microscopy the structure of BM varies somewhat in relation to the cell type with which it is associated. With conventional (uranium and lead) staining most BM show a zone of low electron density adjacent to the cell membrane (lamina lucida or lamina rara) and a zone of higher electron density adjacent to the connective tissue (lamina densa), both of $40-60 \mathrm{~nm}$ thickness (1). Some BM, as for example the lens capsule or Descemet's membrane, consist of a lamina densa only (11). Most other BM contain a lamina rara as well as a lamina densa whereas occasionally, e.g. in the glomerulus or alveolus, the BM is trilaminar due to the juxtaposition of epithelial and endothelial BM $(12,13)$.

\subsection{BASEMENT MEMBRANE COMPOSITION}

BM are relatively insoluble and therefore biochemical analysis of some of the components has been rather complicated. The availability of transplantable neoplasms which produce large quantities of BM matrix, such as the EHS sarcoma (14) and the parietal yolk sac tumor, $(15,16)$ has facilitated the study of the chemical structure of its components. The human placenta has served as a readily available source of $\mathrm{BM}$ of a more physiological nature $(17,18)$.

Many substances have been found in BM. A number of these, e.g., fibronectin, type $V$ collagen and entactin, do not occur exclusively in BM (19-21) and are not, or not only as is the case for entactin, synthesized by epithelial and enclothelial cells, which are actively involved in the production of BM.

Other components occur exclusively in BM and are thought to be produced by the cells which rest upon them. These components, which have been designated "intrinsic components" (1), as well as their most important characteristics are listed in Table 1 ..

Table 1. Characteristics of intrinsic basement membrane components

\begin{tabular}{|c|c|c|c|}
\hline Component & Molecular structure & MW & Ref. \\
\hline $\begin{array}{l}\text { Type IV } \\
\text { collagen }\end{array}$ & $\begin{array}{l}\alpha \text { (IV), } \alpha 2 \text { (IV) } \\
\text { triple helix, } \\
\text { rod-like }\end{array}$ & $\begin{array}{l}170-194 \mathrm{kD} \\
\text { per shain }\end{array}$ & $22-27$ \\
\hline Laminir & $\begin{array}{l}\text { three chains, } A, B 1, B 2 \\
\text { cross like structure, } \\
\text { one long arm, three short arms }\end{array}$ & $\begin{array}{l}\mathrm{A} 440 \mathrm{kD} \\
\mathrm{B} 1225 \mathrm{kD} \\
\mathrm{B} 2205 \mathrm{kD}\end{array}$ & $28-36$ \\
\hline $\begin{array}{l}\text { Heparan sulphate } \\
\text { proteoglycan }\end{array}$ & $\begin{array}{l}\text { heterogeneous: protein core }(20 \%) \text {, } \\
\text { GAG side chains }(80 \%)\end{array}$ & $160-750 \mathrm{kD}$ & 37.40 \\
\hline Nidogen & $\begin{array}{l}\text { rod-like with two globular } \\
\text { extensions }\end{array}$ & $150 \mathrm{kD}$ & $41-43$ \\
\hline
\end{tabular}


Type IV collagen, as other collagens, has a triple helical configuration, formed by two different chains $\alpha 1$ (IV) and $\alpha 2$ (IV) (22), in a hetero-/or homotrimeric configuration. A large globular domain, referred to as the noncollagenous domain-1(NCI), is localized at the carboxy-terminal of type IV collagen. Disulphide bridges formed between the $\mathrm{NCl}$ domains, lead to dimers of type IV collagen molecules (23). Disulphide bridge formation between the four amino terminal parts (7-S domains) also leads to the formation of anti-parallel overlapping tetramers of type IV collagen (24). In addition to end-to-end binding, lateral associations between type IV collagen molecules are involved in the stabilization of the network (25). Short non-helical parts increase the flexibility but also the susceptibility to proteolytic damage (26). Type IV collagen contains high amounts of carbohydrate side-chains, which in addition to the other glycoprotein components of BM may explain the PAS positive staining reaction of BM in tissue sections. The flexible network formed by type IV collagen molecules is the structural backbone of the BM, to which the other components can bind. Specific binding sites on the type IV collagen molecule have been localized for laminin, heparan sulphate proteoglycan and fibronectin (27). Laminin is a noncollagenous glycoprotein. The molecule has a cross-like configuration, consisting of a $75 \mathrm{~nm}$ long arm and three $35 \mathrm{~nm}$ short arms which are connected with disulphide bonds. (28). The end of the short arm is formed by two small globular parts, the end of the long arm by one larger globular part. The laminin molecule contains one A chain (MW $440 \mathrm{kD}$ ), one B1 chain (MW $225 \mathrm{kD}$ ) and one B2 chain (MW $205 \mathrm{kD}$ ). Each chain begins as a short arm, they join in the center and the rest of the chains projects down the long arm $(29,30)$. Globular domains at the end of the short arms bind to type IV collagen (31). The central part of the laminin molecule interacts with cell surfaces by binding to plasma membrane receptors $(32,33)$. Binding to heparan sulphate proteoglycan is realized by specific domains at the long arm (34). Immunocytochemical studies at light and electron microscopical level have shown that laminin occurs exclusively in BM, especially in the lamina rara (35). However, other investigators found also localization in the lamina densa (36).

Heparan sulphate proteoglycan (HSPG) consists of a core protein, to which side chains of glycosaminoglycans are bound $(37,38)$. More than $50 \%$ and maybe even $80 \%$ of the molecule consists of glycosaminoglycans (38). The core protein has a structure which is unique for BM HSPG (38). The core protein of bovine glomerular BM HSPG (MW $128 \mathrm{kD}$ ) has been identified (39). HSPG occurs in the BM as aggregated clusters in the lamina rara (7). It probably plays a role in the attachment of cells to BM and, by means of its anionic properties, in the regulation of glomerular filtration $(6,7)$. Besides HSPG, other proteoglycans, bearing chondroitin sulphate and dermatan sulphate side chains, have been found in BM (40).

Intact nidogen has a $\mathrm{MW}$ of $150 \mathrm{kD}$, and is highly susceptible to proteolysis (41, 42). The self aggregating tendency and binding to laminin and type IV collagen strongly suggests that nidogen may serve as a bridging molecule within the BM (43). 
Immunostaining with antibodies to nidogen was restricted to BM and showed codistribution with laminin (41). In addition to components present in almost all BM, other structural components have been identified, which do not localize in all BM. Some of them are not restricted to BM and have been found in interstitial stroma. Entactin is a highly sulphated glycoprotein with a MW of $145 \mathrm{kD}$ (44). Although in earlier reviews $(1,45)$ entactin, was considered to be an intrinsic component, recent studies (21) have shown that it is mainly a product of stromal fibroblasts. Ultrastructural localization of entactin demonstrated variations in localization of entactin within the BM of different rat tissues (46). Evidence has been published which suggests that entactin and nidogen might be identical (42).

Bullous pemphigoid antigen is a glycoprotein (MW 220-240 kD) restricted to stratified squamous epithelium and localized in the lamina rara and or hemidesmosomes $(47,48)$. The origin of the bullous pemphigoid antigen is still a matter of debate: a $\mathrm{BM}$ association is still conceivable but some authors claim that it is an epithelial cell membrane antigen (49).

Fibronectin exists in two forms, the soluble plasma form, and the insoluble tissue form (50). The " $\mathrm{V}$ "-shaped molecule is a glycoprotein (MW $440 \mathrm{kD}$ ), composed by two polypeptides of $220 \mathrm{kD}$. Immunolocalization of fibronectin results in interstitial stroma and BM localization $(51,52)$. One of the main functions of fibronectin is the binding of cells to matrix components (50).

Type $\mathrm{V}$ collagen is composed by three distinct $\alpha$ chains, $\alpha 1(\mathrm{~V}), \alpha 2(\mathrm{~V}), \alpha 3(\mathrm{~V})$, the molecular structure resembles type IV collagen (53). Interstitial stromal localization, as well as close relation to the stromall side of vascular BM has been found (54). Epidermolysis bullosa acquisita antigen has a native $\mathrm{MW}$ of over $800 \mathrm{kD}$ and is composed by a major chain of $290 \mathrm{kD}$ and a minor chain of $145 \mathrm{kD}(55,56)$. The antigen has been identified as the collagenase insensitive globular domain of type VII collagen (57). This glycoprotein with collagen-like domains probably plays a role in dermal-epidermal adherence $(56,57)$.

Further evidence for the existence of other components can be derived from a study by Hessle et al. (58). These investigators generated monoclonal antibodies against placental membranes and found several BM-specific antibodies which did not react with one of the known components. Another interesting finding was that some antibodies detected epitopes which occurred only on some BM and not on others. Heterogeneity of BM constituents and changes during ontogenesis were observed in human kidneys with monoclonal antibodies to BM components (59).

These data suggest that there may be significant heterogeneity between BM of different cells and tissues. Recently, in our laboratory we raised monoclonal antibodies to BM components by immunizing with amnionic membranes. These antibodies show organ as well as species specificity and lack immunoreactivity to known BM components (60). 


\subsection{CELL-BINDING TO BASEMENT MEMBRANES}

In immuno-electron microscopic studies laminin has been localized very close to the plasma membrane (61). Furthermore, laminin binding proteins (MW $70 \mathrm{kD}$ ) have been extracted from tumor cells and normal muscle cells (62-64). Specific laminin receptors on the cell surface and laminin-cell interactions have been extensively reviewed elsewhere (65). Recently, evidence has been found for the existence of two distinct cell-membrane receptors for laminin, one binding to fragment 1 on the short arm and the other to fragment 8 on the long arm (66). A glycoprotein complex, cell substratum attachment (CSAT) antigen (MW $140 \mathrm{kD}$ ), which binds to laminin and fibronectin, has been isolated from fibroblasts and myoblasts $(67,68)$. Amino acid sequences of receptor binding sites have been localized on fibronectin and laminin $(69,70)$. A special surface associated protein involved in binding of cells to type IV collagen has been found earlier (71).

\subsection{BASEMENT MEMBRANES IN CANCER}

Studies of BM in cancer have mainly focused on two distinct areas. Firstly, BM have been investigated in relation with tumor invasion and metastasis. Secondly, the production of $\mathrm{BM}$ components as a marker of cellular differentiation has been explored.

\subsubsection{Basement membranes and invasion}

Tumor invasion can be defined as the extension of neoplastic cells beyond the natural borders of the tissue or cell type from which they derive. As a result of this active process of infiltrative growth the neoplastic cells occur in tissue compartments where they do not belong. For epithelial tissues BM are the natural borders. In invasive carcinoma for example, the malignant epithelial cells penetrate the epithelial $\mathrm{BM}$ and migrate into the surrounding mesenchymal stroma. Prior to the development of hematogenous metastases the carcinoma cells have to gain access to the vascular lumen. During this process the invasive cells have to penetrate a second - the endothelial - BM. At the site of the development of a hematogenous metastasis the embolized neoplastic cells again traverse the endothelial BM. It appears therefore that in the process of invasion and metastasis the interaction between neoplastic cells and BM plays a pivotal role.

The study of BM morphology in invasive cancer is not entirely new. Early attempts by Ozzello (9) to outline BM in breast cancer by PAS staining, were frustrated by the occurrence of PAS reactive glycoproteins not only in BM but also in interstitial connective tissue. Electron microscopy appeared to be a more suitable technique for the study of BM (72). Several ultrastructural investigations have been published, describing BM or basal lamina morphology in a variety of cancer types. Zelickson 
(73) was among the first, reporting on the continuity of the BM around basocellular carcinomas. Other investigators, however, reported discontinuity in BM in connection with this type of neoplasm $(74,75)$ Gould and coworkers $(76-78)$ published several sudies on the BM (which in this context they preferred to call basal lamina) in epithelial neoplasms. Their studies showed a very broad spectrum of patterns of BM deposition in carcinomas. In the breast, for example, BM deposition appeared to parallel myoepithelial differentiation, being notably absent, e.g., in tubular carcinoma (78). Well differentiated squamous cell carcinomas in general retained their ability to deposit a BM but undifferentiated carcinomas showed only scanty BM production (76). Particular $l y$ interesting was the finding of BM synthetic capacity in metastatic neoplastic cells as well as the occurrence of interruptions or "gaps" in BM in in situ or borderline lesions (76). In a recent study of squamous cell carcinomas of the lung Dingemans and Mooi $(79,80)$ showed that in the expanding periphery of the tumor, nests of tumor cells were often surrounded by the BM of the original alveolar epithelium. In addition, isolated single and highly irregular clusters of tumor cells, as well as tumor cells which had invaded bloodvessels, were always surrounded by a basal lamina, which was presumably newly formed.

Taken together these ultrastructural observations show that in some in situ and borderline lesions and in most invasive carcinomas defects in the BM occur. On the other hand carcinoma cells often retain the possibility to deposit BM material, even in metastatic foci. These findings are difficult to reconcile with the conventional concept of passive piercing of the BM by aggressively infiltrating tumor cells.

In recent years immunocytochemical localization of BM components has greatly expanded the possibilities to study BM in cancer. Initial studies in this area, using naturally occurring antibodies against bullous pemphigoid antigen, supported ultrastructural findings of BM defects in basocellular cancer of the skin (81). However, using antibodies to laminin and type IV collagen, continuous BM were found in basal cell carcinoma, whereas bullous pemphigoid antigen showed complete absence (82). Albrechtsen et al. (83) were among the first to show by immunocytochemical staining of defined BM components that in the breast in situ carcinomas, intralobular or intraductal proliferations of neoplastic epithelial cells, are surrounded by an intact BM. In contrast, invasive carcinomas showed BM with focal defects, especially in areas of invasion. Similar findings were reported by Siegal et al.(84). In addition, these investigators found cytoplasmic immunoreactivity for laminin and type IV collagen in primary as well as in metastatic tumor cells. Burtin et al.(85) performed an immunofluorescence study on colonic adenocarcinomas and found weaker and more irregular staining than in normal mucosa, resulting in patchy BM patterns. Subsequent immunocytochemical studies of a variety of carcinomas in different tissues have shown that in the majority of benign and in situ lesions BM can be detected in a normal continuous configuration whereas in the majority of invasive lesions, focal, partial or complete absence of BM components is found. Initial reports focused on continuity of BM in benign neoplasms, discon- 
tinuous and irregular basements membranes in in situ lesions and absence of BM in invasive carcinomas $(86,87)$. However in some benign neoplasms, such as syringomas and pilomatrixomas of the skin (88) and pleomorphic adenomas of the salivary gland (89), BM discontinuities have been found. Conversely, in some malignant neoplasms, such as adenoid cystic carcinomas of the salivary gland (89) and laryngeal squamous cell carcinoma $(90,91)$, the BM remains intact. A brief summary of the findings in various tumors in different organs is given in Table 2 .

Table 2 Basement membrane alterations in benign and malignant human neoplasms.

\begin{tabular}{|c|c|c|c|}
\hline Organ & Type of neoplasm & Basement membrane morphology & Ref. \\
\hline \multirow[t]{6}{*}{ Skin } & Squamous cell carcinoma & Focal gaps to extensive loss & $91,92,93$ \\
\hline & Basal cell epithelioma & Intact, continuous & $91,92,93$ \\
\hline & \multirow{2}{*}{ Benign adnexal tumors } & Distinct, continuous & \multirow[t]{2}{*}{88} \\
\hline & & In some tumor types discontinuous & \\
\hline & Keratoacanthoma & Discontinuities & 94 \\
\hline & Malignant adnexal tumors & Discontinuous or lacking & 88 \\
\hline Head & Squamous cell carcinoma & & \\
\hline \multirow[t]{3}{*}{ and Neck } & Oropharynx & \multirow{3}{*}{$\begin{array}{l}\text { Well developed, focal discon- } \\
\text { tinuities }\end{array}$} & 90,91 \\
\hline & Tongue & & 90 \\
\hline & Larynx & & $90,91,95,96$ \\
\hline \multirow[t]{4}{*}{ Breast } & Fibroadenoma & Intact, continulous & $83,84,92$ \\
\hline & Sclerosing adenosis & Intact, continuous & $\begin{array}{l}83,84,86,87 \\
97\end{array}$ \\
\hline & Adenocarcinoma & Discontinuous or lacking & $83,84,86,87$ \\
\hline & & & 92,97 \\
\hline \multirow[t]{2}{*}{ Colon } & Adenoma & Intact, continuous & 85,86 \\
\hline & Adenocarcinoma & Discontinuous or lacking & $85,86,116$ \\
\hline \multirow[t]{2}{*}{ Pancreas } & Islet cell adenoma & Intact, continuous & 98 \\
\hline & Adenocarcinoma & Irregular, discontinuous & 86,98 \\
\hline \multirow[t]{2}{*}{ Prostate } & Hyperplasia & Intact, continuous & 86 \\
\hline & Adenocarcinoma & Discontinuous or lacking & 86 \\
\hline Salivary & Pleomorphic adenoma & Poorly developed, discontinuous & 89 \\
\hline \multirow[t]{3}{*}{ gland } & Adenoid cystic carcinoma & Intact, continuous & 89 \\
\hline & Warthin's tumor & Intact, continuous & 89 \\
\hline & Mucoepidermoid tumor & Discontinuous or lacking & 89 \\
\hline \multirow[t]{3}{*}{ Uterus } & Endometrial & & \\
\hline & adenocarcinoma & Discontinuous or lacking & 86,118 \\
\hline & $\begin{array}{l}\text { Squamous cell carcinoma } \\
\text { of cervix }\end{array}$ & Intact or focal gaps & 92,102 \\
\hline \multirow[t]{2}{*}{ Lung } & Adenocarcinoma & Intact, continuous & 87,92 \\
\hline & Squamous cell carcinoma & Irregular, discontinuous & 87,92 \\
\hline
\end{tabular}

The lack of immunoreactivity for BM components in the majority of invasive carcinomas is in concert with conventional concepts regarding the progression of in situ to invasive lesions. 
Invasive tumor cells penetrate the original BM and are then no longer demarcated by this barrier (99). If consistent and reproducible this phenomenon would be very usefull for the distinction between pre-invasive (in situ) and invasive lesions. It is quite evident, however, that BM defects are neither a sine qua non for an invasive, malignant lesion nor a specific hallmark of invasion. In well differentiated squamous cell carcinomas and in endometrial adenocarcinomas ultrastructural studies (78) and immunohistochemical studies $(100,101)$ have shown the consistent presence of $\mathrm{BM}$ deposits, observations which are somewhat at variance with previous histochemical studies $(8,86)$. On the other hand focal BM defects occur in in situ lesions (96). The latter observation is rather intriguing and suggests that prior to morphologically recognizable invasive growth the original BM may be disrupted. In reality, therefore, the situation is quite a bit more complex than the conventional concept of progression from in situ to invasive neoplasia suggests. Intact BM can. occasionally be found in invasive lesions and, conversely, in noninvasive lesions BM defects may occur. BM defects even occur in inflammatory conditions when the epithelium is invaded by leucocytes $(96,98,100-102)$.

An unresolved problem in this context is that the results of ultrastructural studies are not completely congruent with those of immunocytochemical studies. In several types of cancer by electron microscopy continuous BM were detected whereas immunocytochemical studies in similar lesions showed focal BM defects $(8,76,79,80$, 86). Several factors should be considered in explaining for these discrepancies. Firstly there may be a sampling problem: immunocytochemistry allows the screening of large areas of tumor tissue whereas by electron microscopy a thin basal lamina may be detected which, especially after tissue processing procedures, might escape immunocytochemical detection. Secondly, differences in the approach of the problem may have played a role: electron microscopists have almost invariably looked for pericellular deposition of BM material $(76,79,80)$, whereas immunocytochemists have emphasized the occurrence of $\mathrm{BM}$ interruptions $(8,86)$. It is evident that additional electron-immunocytochemical studies are necessary to resolve this issue. These contrasting observations quite naturally lead to the question of what mechanisms are involved in the generation of BM discontinuities. It should be emphasized here that the $\mathrm{BM}$ is not a static structure but is continuously catabolized and redeposited (1.03). If the idea of mechanical rupture of the BM due to expansive tumor growth is dismissed as being too simplistic, the conclusion remains that BM defects are caused by an imbalance between breakdown and production. This could be due to increased degradation by cancer cells or to decreased synthesis or decreased assembly of BM constituents or a combination of these processes. That actively invasive cancer cells degrade rather than accumulate BM is supported by several observations. Many types of human and murine tumor cells have been shown to degrade BM in vitro (104-108). Liotta et al $(104,105)$ described a collagenase specific for type IV collagen whose production correlated with the metastatic potential of a series of B16 melanoma sublines. Kramer et al. (106, 107) 
identifted an endoglycosidase in B16 melanoma cells which selectively degraded heparan sulphate proteoglycan. Human breast carcinoma cells have been shown to contain immunoreactive type IV collagen specific collagenases (109). The degradation of the BM by leukocytes in inflammatory reactions $(94,110,111)$ is also supportive of enzymatic catabolism as an important mechanism. The evidence in favor of insufficient synthesis or defective assembly of BM components by cancer cells is scanty. The most important observation in this respect is the occurrence of intracytoplasmic immunoreactivity for laminin and type IV collagen in invasive or metastatic tumor cells, even in the absence of an extraceliular formed BM $(83,86$, 96). The role of laminin in the attachment of cells to the extracellular matrix suggests that this protein or its cell surface receptor may have an important function in the attachment of circulating tumor cells in the initial phase of the development of a metastasis. Evidence in favor of this suggestion has been reported by Varani et al (112).

\subsubsection{Basement membrane components as markers of cellular differentiation}

This aspect of $\mathrm{BM}$ in cancer has not been extensively studied as yet. In principle, BM deposition can be considered as an indicator for the type of differentiation but can also be correlated with the degree of differentiation of a particular neoplasm. BM deposition is a helpful marker in the classification of soft tissue tumors (113-115). In these studies it was shown that immunoreactivity for laminin and type IV collagen is intense in Schwannomas and neurofibromas, less intense in leiomyomas and leiomyosarcomas but negative in fibrous histiocytomas and fibrosarcomas. These promising observations suggest that BM immunocytochemistry may be a useful method for soft tissue tumor classification but additional studies on a large number of various neoplasms will be necessary to validate this suggestion. For the classification of epithelial neoplasms BM may be less helpful. In a study of malignant adnexal tumors of the skin Kallioinen et al. (88) did not find consistent patterns of BM immunostaining of the different types of adnexal tumors.

Several observations support the idea that BM deposition and the degree of differentiation of a carcinoma may be correlated. Firstly, this idea would be consistent with the role of BM in cytodifferentiation and morphogenesis (5). Secondly, culturing of cells on intact BM resulted in organized cell-cell relations and differentiated cytoskeletal polarity $(120,121)$. Thirdly, in our own immunohistochemical studies on colorectal neoplasms BM were consistently present in well differentiated carcinomas but completely absent in poorly differentiated carcinomas. Similar observations were reported by other authors $(85,116-119)$ and, by electron microscopy, by Gould et al. (78). On the other hand, in malignant adnexal tumors of the skin such a correlation was less apparent (88). It is far too early to draw any conclusions but the available information warrants further studies on the significance of BM deposition as a differentiation marker in neoplasia. 


\subsection{AIM OF THE STUDY}

From the previous paragraphs it can be concluded that BM play an important role in tumor cell-extracellular matrix interactions, especially with regard to invasion and metastasis. Reliable and reproducible visualization of specific BM components by microscopic histochemical techniques is one of the essential tools to the study of the role of $\mathrm{BM}$ in tumor cell-extracellular matrix interactions. To attain that goal specific antibodies to $\mathrm{BM}$ had to be raised and characterized. Chapter 2 describes the production of two monoclonal antibodies and a polyclonal antiserum to the human type IV collagen, and their immunohistochemical application. In chapter 3, BM deposition of human epithelial tumor cell-lines is studied in vitro and in xenografts of these tumor cells in nude mice and rats. Because of the human specificity of the monoclonal antibodies to type IV collagen, and the cross-species reactivity of the polyclonal antiserum, it became possible to speculate on the origin of type IV collagen deposited in BM at the tumor-stroma interface in xenografts. Using the obtained antibodies to type IV collagen on suitable treated routinely processed human tumor tissues, as described in chapter 2, a retrospective study of patterns of BM deposition in a large number of colorectal carcinomas could be performed. Chapter 4 deals with the relation between the patterns of BM deposition and prognosis in colorectal cancer, which is largely determined by the capacity of the tumor to invade the vascular system and produce liver metastasis. Applicability of the antibodies to routinely processed tissues and the avallability of a computerized data base, containing clinicopathological as well as survival data, strongly facilitated this study. In the literature many discrepancies exist between ultrastructural (morphological) observa* tions and light microscopic (immunohistochemical) observations on BM occurrence in neoplasia. These discrepancies prompted us to perform a comparative study on BM patterns in squamous cell carcinomas of the lung by electron microscopy and immunohistochemistry. In chapter 5 , this study is reported with special emphasis on the differences between tumor center and tumor periphery, which appeared to show remarkable differences with interesting biological implications. Nevo-melanocytic lesions often generate serious diagnostic problems. The only two published studies dealing with immunohistochemical detection of BM in newo-melanocytic lesions showed remarkable discrepancies of the results concerning BM deposition at the border of nevo-melanocytic cells and the adjacent stroma. In chapter 6 we describe BM patterns in benign and malignant nevo-melanocytic tumors and critically discuss the potentials for application of BM immunohistochemistry in diagnostic immunohistopathology. Finally, in chapter 7 , the results of these studies concerning BM deposition in neoplastic lesions are discussed against the background of the recent literature concerning tumor cell-extracellular matrix interactions, and future prospects are speculated upon. 


\subsection{REFERENCES}

1. Martinez-Hernandez A, Amenta PS. The basement membrane in pathology. Lab Invest 1983; 48: 656-677.

2. Kleinman HK, Klebe R, Martin GR. Role of collagenous matrices in the adhesion and growth of cells. J Cell Biol $1981 ; 88: 473-485$.

3. Vracko R, Benditt EP. Basal lamina: the scaffold for orderly cell replacement. J Cell Biol 1972; 55: 406-419.

4. Viacko R. Basal lamina scaffold: Anatomy and significance for maintenance of orderly tissue structure. An J Pathol 1974; 77: 314-338.

5. Hay ED. Role of basenent membranes in development and differentiation. In: Biology and chemistry of basement membranes. N. Kefalides, Ed. Academic Press, New York, 1978: 119-136.

6. Rehke HG, Cotran RS, Venkatachalan MA. Role of molecular charge in glomerular permeability: Tracer studies with cationized ferritin. J Cell Biol 1975; 67: 638-646.

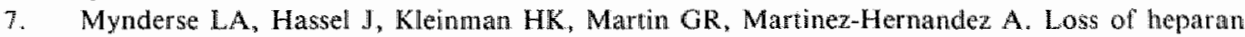
sulfate proteoglycan from glomerular basement membrane of nephrotic rats. Lab Invest 1983; 48: 292-302.

8. Liotta LA, Rao CN, Barsky SH. Tumor inwasion and the extracellular matrix. Lab Invest 1983; 49: $636-649$.

9. Ozello L, Speer FD. The mucopolysaccharides in normal and diseased breast: Their distribution and significance. An J Clin Pathol 1958; 34: 993-1009.

10. Haas E. Diagnostic special stains for surgical pathology. Lippincott, Philadelphia, 1981 .

11. Jakus MA. Ocular fine structure. Little, Brown \& Co.,Boston, 1964.

12. Thorning D, Vracko R. Renal glomerular basal lamina scaffold: Embryologic development, anatomy and role in the cellular reconstruction of rat glomerulan irnjured by freezing and thawing. Lab Invest 1977; 37: 105-1 19 .

13. Groniowsky JA. Ultrastructure of the pulmonary alveolar lining layer. Washington, National Science Foundation, 1983.

14. Timpl R, Rohde H, Gehron-Robey P, Rennard SI, Foiddart JM, Martin GR. Laminin. A glycoprotein from basement menbranes. J Biol Chem 1979; 253: 9933-9937.

15. Chung AE, Jaffe R, Freeman IL, Vergues J, Bragniski JE, Carlin B. Properties of a basement membrane related glycoprotein synthesized in culture by a mouse embryonal carcinoma derived cell line. Cell 1979; 16: 277-287.

16. Timpl R, Martin GR, Bruckner P, Wick G, Wiedeman H. Nature of the collagenous protein in a tumor basement membrane. Eur I Biol Chem 1978; 84: 43-52.

17. Sage H, Woodbury RG, Bornstein P. Structural studies on human type IV collagen. J Biol Chem 1979; 254: 9893-9900.

18. Rhodes RK, Miller EJ. Physicochemical characterization and molecular organization of collagen $A$ and $B$ chains. Biochemistry 1978; 17: 3442-3448.

19. Martinez-Hernandez A, Marsh CA, Clark CC, Macarak EJ, Brownell AG. Fibronectin. its relationship to basement membranes. 11. Ultrastructural studies in rat kidncy. Collagen Rel Res $1982 ;$ 1: $405-411$.

20. Martinez-Hernandez A, Gray S, Miller EJ. Ultrastructural localization of type V collagen in rat kidney. J Cell Biol $\rrbracket 982 ; 92: 343-349$.

21. Warburton MJ, Monaghan P, Ferns SA, Rudland PS, Perusinghe N, Chung AE. Distribution of entactin in the basement membrane of the rat mammary gland. Exp Cell Res 1984; 152: $246-254$.

22. Timpl R, Oberbaumer I, Furthmayer $\mathbf{H}$, Kuehn $\mathrm{K}$. Macromolecular organization of the basement membrane. In: New trends in basement membrane research, Ed. by Kuehn K, Schocne H.H, Timpl R. Raven Press, New York, 1982: 57-67.

23. Timpl R, Weidemann $H$, Van Delden V, Furthmayr H, Kühn K. A neiwork model for the organization of type IV collagen molecules in basement membranes. Eur J Biochem 1981; 120: 203-211.

24. Glanwille RW, Qian R, Siebold B, Risteli J, Kühn K. Amino acid sequence of the N-terminal aggregation and cross-linking region (7-S domain) of the $\alpha 1$ (IV) chain of human basement membrane collagen. Eur J Biochen 1985; 152: 213-219. 
25. Yurchenco PD, Funhmayr H. Self-assembly of basenent membrane collagen. Biochem $1984: 23$. 1839.1850

26. Hofmann H, Voss $T$, Kühn K. Localization of flexible sites in thread-line molecules from electron micrographs. Comparison of interstitial , basement membrane and intirna collagens. J Mol Biol 1984: $172: 325-343$.

27. Laurie GW , Bing JT, Kleinman HK, Hassell JR, Aumailley M, Martin GR, Feldman RJ. Localization of binding sites for laminin, heparan sulfate proteoglycan and fibronectin on basement membrane (nype IV) collagen. I Mol Biol 1986; 189: 205-216.

28. Engel J, Odermati $\mathbb{E}$, Engel $A$, Madri JA, Furthmayer H, Rohde H, Timpl R. Shapes, dlomain organization and flexibility of laminin, and fibronectin, two multifunctional proteins of the ex. tracellular matrix. IN Mol Biol 1981; 150: 97-120.

29. Palm SL, McCarthy JB, Furcht LT. Alternative model for the internal structure of laminin. Biochem 19:5; 24: 7753-7760.

30. Paulsson M, Deutzmann R, Timpl R, Dalzoppo D, Odermatt E, Engel II. Evidence for coiled-coil $\alpha$-helical regions in the long arm of laninin. EMBO $\mathrm{J} 1985 ; 4: 309-316$.

3. Charonis A.S, Tsilibary EC, Yurchenco PD, Furthmayr H. Binding of laminin to type IV collagen: a morphological study. J Cell Biol 1985; 100: 1848-1853.

32. Timpl R, fohtansson $\mathrm{S}$, Van Delden $V$, Oberbäumer $\mathbb{1}$, Hö K M. Characterization of protease resistant fragments of laminin mediating attachment and spreading of rat hepatocytes. $J$ Biol Chem 1983; 259: 8922-8927.

33. Terranova VP, Rorhbach DH, Martin GR. Role of laminin in the attachment of PAM 212 (epithelial) cells to basement membrane collagen. Cell 1980; 22: 719-726.

34. Timpl R, Fujiwara S, Dziazek M, Aumailley M, Weber S, Engel J, Laminin, proteoglycan and collagen IW. Structural models and molecular interactions. In: basement membranes and cell movement. Ciba Found Symp 108 London: Pitman Publishing, Ltd, 1984; 2543.

35. Foidart J-M, Berc JW, Yaar M, Rennard SI, Gullino M, Martin GR, Katz SI. Distribution and immunowelectron microscopic localization of laminin, a non-collagenous basement membrane glycoprotein. Lab Invest 1980; 42: 336-342.

36. Abrahamson DR. Postembedding colloidal gold innmunolocalization of laminin to the lamina rara interna, lamina densa, and lamina rara externa of renal glomerular basement membranes. J Histochem Cytochem 1986; 34: 847-853.

37. Parthasavathy N, Spiro RG. Characterization of the glycosaminoglycan component of the renal glomerular basement membrane and its relationship to the peptide portion. II Biol Chem 1981; 256: $507-513$.

38. Hassel JR, Robey PG, Baranch H.J, Wilczek J, Rennard SI, Martin GR. Isolation of a heparan sulphate proteoglycan from basement membrane. Proc Natl Acad Sci U.S.A. 1980; 77: 4494. 4498.

39. Edge ASB, Spiro RG. Selective deglycosylation of the heparan sulfate proteoglycan of bovine glomerular basement membrane and identification of the core protein. J Biol Chem 1987; 262: $6893-6898$.

40. Brentan MJ, Oldberg $\AA$, Pierschbacher MD, Ruostahti E. Chondroitin/dermatan suffate prom teoglycan in human fetal membranes: demonstration of antigenical similar proteoglycan in fibroblasts. J Biol Chem 1984: 259: 13742-13750.

41. Timpl R, Dziadek M, Fujiwara $S$. Nowack $H$, Wick. G. Nidogen: a new self aggregating basement membrane protein. Eur J Biochem 1983; 137: 455-465.

42. Paulsson $M$, Deutzmann $R$, Dziadek $M$, Nowack $H$, Timpl $R$, Weber $S$, Engel J. Purification and structural characterization of intact and fragmented nidogen obtained from a tumor basement membrane. Eur J Biochem 1986; 156: 467-478.

43. Dziadek $\mathrm{M}$, Paulsson $\mathrm{M}$, Timpl $\mathrm{R}$. Identification and interaction repertoire of large forms of the basement membrane protein nidogen. EMBO I 1985; 4: 2513-2518.

44. Carlin B, Jaffe R, Bender B, Chung AE. Entactin a novel basal lamina associated sulfated glycoprotein I Biol Chem 1981; 256:5209-5214.

45. Scott PG. Macromolecular constituents of basement membranes: A review of current knowledge on their structure and function. Can J Biochem Cell Biol. 1983; 61: 942-948.

46. Martinez-Hernandez A, Chung AE. The ultrastructural localization of two basement membrane 
components: entactin and laminin in rat hssues. Nistochem Cytochem 1984; 32: 280298.

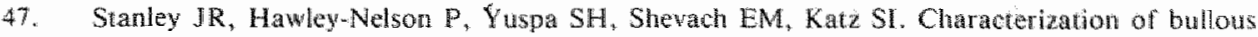
pemphigoid antigen: A unique basment membrane protein of strathed squamots aphelia. Cell $1981 ; 24: 897-903$.

48. Stanley JR, Woodley DT, Katz SI. Identification of pemphigoid antigen extracted from nomal humar skir. J Invest Derm 1984; 82: 108-111.

49. Horiguchi $Y$, inamura $S$. Discrepancy between the localization of in vivo bound immunoglobu. lins in the skin and in vitro binding sites of circulating anti-BMZ antibodies bn bullous penphigoid: Immuno-electron microscopic studies. J Invest Dermatol 1986: 87: 715-719.

50. Hynes $\mathbb{R}$. Molecular biology of fibronectin. Ann Rev Cell Biol 1985; 1:67-90.

51. Gil J, Martinez-Hernandez A. The connective tissue of the rat hang: Electron immunohistochenicall studies. J Histochem Cytochem 1984; $32 ; 230-238$.

52. Torkata $C$, Villiger B, Kuhn C, McDonald JA. Ultrastructural distribution of fibronectin in normal and fibrotic human lung. Lab lnwest $1985 ; 52: 399-408$.

53. Sage H, Bornstein P. Characterization of a novel collagen chain in human placenta and is relation to AB collagen. Biochem 1979; 18: 3815-3822.

54. Martinez-Hernandez A, Gay S, Miller EJ. Ultrastuctural localization of type $V$ collagen in mat kidney. J Cell Biol 1982;92:343-349.

55. Woodley DT, Briggaman RA, O Neefe EI, Inman AO, Queen LL, Gammon WR. Identification of the skin basement membrane autoantigen in epidermolysis bullosa acquisita. N Engl $J$ Med $1984 ; 310 ; 1007-1013$.

56. Woodley DT, O'Keefe EJ, Reese MJ, Mechanic GL, Briggaman RA, Gammon WR. Epidermolysis bullosa acquisita antigen, a new major component of cutaneous basement menorane, is a glycoprotein with collagenous domains. I Inwest Dermatol 1986; 86: 668-672.

57. Woodley DT, Burgeson RE, Lunstrum GP, Reese MJ, Bruckner-I"uderman L, Gammon WR, Briggaman RA. The epidermolysis bullosa acquisita antigen is type VH procollagen. I Invest Dermatol Abstr 1987; 88: 525.

58. Hessle H, Sakai LY, Hollister DW, Burgeson RE, Engvall E. Basement membrane diversity dew tected by monoclonal antibodies. Diferentiation 1984; 26" 49-54.

59. Michael Alt, Yarng JY, Falk RJ, Bennington MJ. Scheimman J.1, Vernier RL, Fist AJ. Monoclonal antbodies to human renal basement membranes heterogenic and ontogenic changes. Kidney International $1983 ; 24: 74-86$.

60. Clleutjens JPM, Havenith MG, Beek C, Vallinga M, Bosman FT. Basenent membrane heterogeneity detected by monoclonal antibodies. Acta Histochem in press.

61. Abrahamson DR, Caulfield JP. Distribution of laminin within rat and motuse renal, splenic, intestinal and hepatic basement membranes identified after intravenous injection of heterologous anti-laminin IgG. Lab Invest 1985; $52: 169-181$.

62. Rao NC, Barsky SH, Terranova VP, Liotta LA. Isolation of a tumor cell Iaminin receptor. Biochem Biophys Res Com 1983; 111: 804-808.

63. Matinof $\mathrm{H}$, Whoha MS, Isolation of all surace receptor protein for laminim from murine fibrosarcoma cells. J Cell Biol 1983; 96: 1475-1479.

64. Lesot H, KuhU, von der Mark K. Isolation of a lamina binding proten from muscle cell membranes. EMBO J 1983; 2: 861-865.

65. von der Mark K, KühI U. Laminin and its recepior. Biochem Brophys Acia 1985: 823: 147-160

66. Aumailley M, Nurcombe V, David E, Paulsson M, Timpl R. The collular interactions of laminin fragnents: Cell adhesion correlates whth wo fragment-specifichigh affinity binding sites. I Biol Chem $1987 ; 262: 11532-11538$.

67. Damsky CH, Knudsen KA, Bradley D, Buch CA, Horwitz AF. Distribution of the cull substrutum attachment (CSAT) antigen on myogenic and fibroblastic cells in culure. 1 Cell Biol 1985; $100: 1528-1539$.

68. Horwitz A. Duggan K, Greggs R, Decker C, Buck C. The cell surface attachment (CSAT) antigen has properties of a receptor for laminin and fibronectin. J Cell Biol 1985; 101; 2134-2144.

69. Ruoshahti E, Pierschbacher MD. Argugly-asp: a versalite cell recognition signal. Cell $1986 ; 44$; 517.518 .

70. Graf J, Iwamoto Y, Sasaki M, Martin GR, Kleinman HK, Robey PA, Yamada Y. Identificathon 
of an amino acid sequence in laminin mediating cell attachment, chemotaxis, and receptor binding. Cell 1987: 48: 989-966.

71. Kurkin $M$, Taylor A, Garrels J, Hogan BL. Cell surface associated proteins which bind to native type IV collagen or gelatin. \Biol Chem 1981; 259: 5915-5922.

72. Ozzello L. Epithelial stromal junctions of normall and dysplastic mammary glands. Cancer 1970; 25: 5866000 .

73. Zelickson AS. Electron microscope study of the basal cell epithelioma. J Invest Dermatol 1962; 39: 183-187.

74. Kobayashi T. Dermo-epidermal junction of basal cell carcinoma. Acta Dermatol Venerol (Stockholm) $1970 ; 50: 401-411$.

75. McNutt NS. Ultrastructural comparison of the interface between epithelium and stroma in basal cell carcinoma and control human skin. Lab Invest 1972; 35: 132-142.

76. Oould $\mathrm{VE}$, Battifora $\mathrm{H}$. Origin and significance of the basal lamina and some interstitial fibrillar components in epithelial neoplasms Pathol Annul 1976; 11: 353-386.

77. Gould VE, Miller J, Jao W. Ultrasinucture of medullary, intraductal, tubular and adenocystic breast carcinomas: Comparative patterns of myoepithelial differentiation and basall laminat deposition. Am J Pathol 1975; 78: 401-416.

78. Gould VE, Sommers SC, Terzakis IA. Squamous differentiation and basal lamina deposition in endometrial adenoacanthoma. Am J Pathol 1978; 83: 25-38.

79. Dingemans K.P, Mooi WJ. Invasion of lung tissue by bronchogenic squamous cell carcinomas: Interaction of tumor cells and lung parenchyma in the tumor periphery. Int J Cancer 1986; 37: 1].19.

80. Dingemans KP, Mooi $W \mathrm{~J}$ : Ultrastructure of tumor invasion and desmoplastic respons of bronchogenic squamous cell carcinoma. Virchows Arch (Cell Pathol) 1987; 411:283-291.

81. De Morages JM, Winkelmann RK, Jordan RE. Immunoltuorescence of epidermal skin tumors. II. Basement membrane Cancer 1970; 25: 1404-1407.

82. Stanley JR, Beckwith JB, Fuller RP, Kaiz SI. A specific antigenic defect of the basement membrane is found in basal cell carcinoma but not in other epidermal tumors. Cancer 1982; 50: $1486-1490$.

83. Albrechtsen $\mathbb{R}$, Nielsen $M$, Wewer $U$, Engwall E, Ruoslahti E. Basement membrane changes in breast cancer detected by immunohistochemical staining for laminin. Cancer Res. 1981; 41: 5076-5081.

84. Siegal GP, Barsky SH, Terranova VP, Liotta LA. Stages of neoplastic transformation of human breast tissue as monitored by dissolution of basement membrane conponents. Invas Metast 1981 ; 1: $54-70$.

85. Burtin P, Chavanel $G$, Foidart JM, Martin $\mathbb{E}$. Antigens of the basement membrane and the peritumoral stroma in human colonic adenocarcinomas: An immunofluorescence study. Int $J$ Cancer. 1982; $30: 13-20$.

86. Barsky $H_{2}$, Siegal GP, Jannotta $F$, Liotta LA. Loss of basement membrane components by invasive tumors but not by their benign counterparts. Lab Invest 1983; 49: 140-147.

87. Birembaut $P$, Caron $Y$, Wan Cauwenberghe $D$. Foidart IM. Distribution of laminin, a basement membrane glycoprotein in epithelial proliferations. Collagen Rel Res 1983; 3:25-31.

88. Kallioinen M, Autio-Harmainen H, Dammert K. Risteli J, Risteli L. Basement membrane laminin and type IV collagen in various benign and malignant adnexal tumors of the skin: An immunohistochemical study. I Invest Dermatiol 1984; 83: 276-280.

89. Toida $M$, Takeuchi J, Hara K, Sobue M, Tsukidate K, Goto K, Nakashima N. Histochemical studies of intercellular components of salivary gland tumors with special reference to glycosaminoglycans, laminin and vascular elements. Virchows Arch (Pathol Anat) 1984; 403: $15-26$.

90. Carter RL, Burman JF, Barr L, Gusterson BA. Immunohistochemical localization of basement membrane type IV collagen in invasive and metastatic squamous carcinoma of the head and neck. JPathol 1985; 147: 159-164.

91. Gusterson BA, Warburton MJ, Mitchell D, Kraft N, Hancock W. Inwading squamous cell carci* noma can retain a bessal lamina: An immunohistochemical study using a monoclonal antibody to type IV collagen. Lab Invest 1984; 51: $82-87$. 
92. Cam $Y$, Bellon $G$, Poulin $G$, Caron $Y$, Birembaut $P$. Distribution of type $I V$ collagen in benign and malignamt epithelial proliferations. Invas Metast 1984; 4:61-72.

93. Kallioinen M, Autio-Harmainen H, Dammert K. Ristelli J, Risteli L. Disconintuty of the basement membrane in fibrosing basocellular carcinomas and basosquamous carcinomas of the skin: An immunohistochemical study with human laminin and type IV collagen anibodies. II Invest Dermatol 1984; 82: 248-25I.

94. McArdle JP, Roff BT, Muller HK, Murphy WH. The basal lamina in basal cell carcinoma, Bowen's disease, squamous cell carcinoma and keratoacanthoma: An immunoperoxidase study usw ing an antibody to type IV collagen. Pathol 1984; 16:67-72.

95. Cam Y, Caulet T, Bellon G, Poulin G, Legros M, Pytlinska M. Immunohistological localization of macromolecules of the basement membrane and peritumoral stroma in human laryngeal carcinoma. J Pathol 1984; 144: 35-44.

96. Visser R, van der Beek JMH, Hawenth MG, Cleutjens JPM, Bosman FT: Immunocytochemical detection of basement membrane antigen in the histopathological evaluation of laryngeal dyspla. sia and meoplasia. Histopathology 1986; 10: 171-180.

97. Gusterson BA, Warburtor MJ, Mitchell D, Ellison M, Neville AM, Rudland PS. Distribution of myoepithelial cells and basement membrane proteins in the normal breast and in benign and malignant disease. Cancer Res 1982; 42; 4763-4770.

98. Haglund $\mathrm{C}$, Nordling $\mathrm{S}$, Roberts, PJ。 Ekblom P. Expression of \aminin in pancreatic neoplasms and in chronic pancreatitis. Am J Surg Pathol 1984; 8: 669-676.

99. Mckinney RV, Singh BB. Basement membrane changes under oral mucous membranes. Ultrastructural observations, review of the literature, unifying concept. Oral Surg $1977 ; 44: 875 \mathrm{~m} 888$.

100. Vogel HP, Mendelsohn G. Laminin immunostaining in hyperplastic, dysplastic and neoplastic lesions of the endometriun and uterine cervix. Obstet Gynecol 1987; 69: 794-799.

101. Sakr WA, Zarbo RJ, Jacobs JR., Crissman JD. Distribution of basement membranes in squamous cell carcinoma of the head and the neck. Hum Pathol 1987; 18: 1043-1050.

102. Stenbäck $F$, Wasenius V-M, Risteli J, Risteli L. Basement membranes in progressing intraepitheli.al cervical neoplasia. Gynecol Obstet Invesi 1985; 20: 158-166.

103. Kefalides $N A_{\text {, Alper }} \mathrm{R}$, Clark $\mathrm{CC}$. Biochemistry and metabolism of basement membranes. Int Rev Cytol 1979; 61: 167-228.

104. Liotta LA, Tryggvason K, Garbisa S, Hart I, Foltz CM, Shajie S. Metastatic potential correlates with enzymatic degradation of basement membrane collagen. Nature 1980; 284: 67-68.

105. Liotta LA, Abe S, Gehron-Robey P, Martin GR. Preferential digestion of collagen by an enzyme derived from metastatic murine tumor. Prac Natl Acad Sci U.S.A. 1979; 76: 2268-2272.

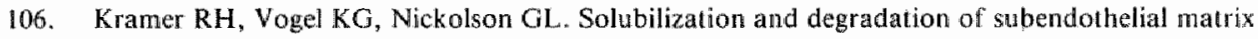
glycoprotein and proteoglycans by metastatic tumor cells. J Biol Chem 1982; 257: 2678-2686.

107. Kramer $\mathrm{RH}$, Vogel KG. Selective degradation of basement membrane macromolecules by metastatic melanoma cells. J Natl Cancer Inst 1984; 72: 889-899.

108. Shields SE, Ogilvie DJ, McKinnell RG,. Tarin D. Degradation of basement membrane collagen by metalloproteases released by human, murine and amphibian iumors. J Pathol 1984; 143: 193.198.

109. Barsky SH, Togo $\mathrm{S}$, Garbisa $\mathrm{S}$, Liotta LA. Type IV collagenase immunoneactiwity in invasive breast carcinoma. Lancet 1983 I: 296-297.

110. Mainardi $C$, Dixit SN, Kang AH. Degradation of type IV (basement membrane) collagen by at proteinase isolated from human polymorphonuclear granulocyles. J Biol Chem 1908; 255: 5435-5441.

111. Pipoly DJ, Crough EC. Degradation of native type IV procollagen by human neutrophil elastase. Implications for leukocyte-mediated degradation of basernent membranes Biochem 1987; 26: $5748-5754$.

112. Varani J, Lovett EJ, McCoy JP, Shibata S, Maddox DE, Goldstein IJ, Wicha M. Differential expression of a laminin- like substance by higl-and low-metastatic tumor cells. Am J Pathol $1983 ; 11: 27-34$.

113. Miettinen M, Foidart JM, Ekblom P. Immunohistochemical demonstration of laminin, the major glycoprotein of basement membranes, as an aid in the diagnosis of sofe tissue tumors. Am J Clin Pathol 1983; 79: 306-311. 
114. D Ardempe Al, Kirkpatrick P. Sykes BC. Distribution of laminin, fibronectin and interstitial colJagen rype III in soft tissue tumors. J Clin Pathol 1984; 37: 895-904.

115. Ogawa $K$, Oguchi $M$, Yamabe $H$, Nakashima $Y$, Hamashima $Y$. Distribution of collagen type IV in sofo tissue tumors. An immunohistochernical study. Cancer 1986; 58: 269-277.

116. Forster SJ, Talbot $1 \mathrm{C}$, Critchley DR. Laminin and fibronectin in rectal adenoearcinoma: Relationship to tumor grade, stage, and metastasis. Br J Cancer 1984; 50:51-60.

117. Grigioni WF, Biagini G, Errico AD, Milani M, Villanacci V, Garbisa S, Mattioli S, Gozzeti G, Mancini AM. Beldaviour of basement membrane antigens in gastric and colorectal cancer. Immunohistochemical study. Acta Pathol Jpn 1986; 36: 173 184.

118. Stenback $F$, Ristel $J$, Risteli L, Wasenius V-M. Basement membrane laminin and type IV collagen in eridometrial adenocarcinoma: Relation to differentiation and treatment. Oncology 1985; 42: $370-376$.

119. Faber M, Wewer LM, Berthelsen JG, Liotta LA, Albrechtsen R. Laminin production by human endometrial stromal cell relates to the cyclic and pathologic state of endomeirium. Am J Pathol $1986 ; 124: 384-398$.

120. Ingber DE, Madri JA, Jamieson JD. Neoplastic disorganization of pancreatic epithelial cell-cell relations. Role of basement membrane. Am I pathol 1985; 121:248-260.

121. Watanabe TK, Hansen LJ, Reddy NK, Kanwar YS, Reddy JK. Differentiation of pancreatic acinar carcinoma cells cultured on rat testicular seminiferous tubular basement membranes. Cancer Res 1984; 44: 5361-5368. 


\section{CHAPTER 2}

\section{Human specific anti-type IV collagen monoclonal antibodies, characterization and immunohistochemical application.*}

\subsection{INTRODUCTION}

Extracellular matrix consists of basement membranes (BM) and interstitial stroma. BM separate epithelia from the stroma and surround individual cells such as adipocytes, muscle cells and Schwann cells (1). BM contribute to the tissue structure, they play a role in cell differentiation, they form semipermeable filtration barriers and they provide scaffolds for tissue repair and regeneration $(2,3)$. All BM contain type IV collagen, laminin and proteoglycans. The type IV collagen molecule is a discontinuous triple helix of about $400 \mathrm{~nm}$ length, composed by two distinct chains $\alpha 1$ (IV) and $\alpha 2$ (IV) $(4,5)$. At the $\mathrm{N}$-terminal region ( $7 \mathrm{~S}$-domain) four type IV collagen molecules are cross-linked and form tetramers. The C-terminal noncollagenous domain (NC1), binds with the NCl domain of another tetramer (6). This supramolecular organization provides a regular flexible network and forms the structural backbone to which other components such as laminin and heparan sulphate proteoglycan can bind (7).

Immunohistochemistry has proven to be a valuable tool for the study of the BM under various physiological and pathological conditions.

Immunohistochemical studies of type IV collagen have yielded important information in regard of the role of BM in developmental biology (8). Monoclonal antibodies, especially human specific antibodies, in combination with cross species reactive polyclonal antisera to type IV collagen have been helpful in studies concerning the origin of this BM component in xenografts of normal and neoplastic human tissues in nude mice (9-11). Furthermore antibodies to BM components have been used in the study of neoplastic disease in diagnostic pathology $(12-15)$. We have developed two new monoclonal antibodies specific for human type IV collagen epitopes in frozen as well as routinely fixed and processed tissue sections. The present paper describes these antibodies and provides optimal procedures for their immunohistochemical application.

\footnotetext{
* Havenith MG. Cleutjens $\mathbb{P} M$, Beek $C$, v.d. Linden E,

De Goeij AFPM, Bosman FT.

Histochemistry $1987 ; 87: 123-128$
} 


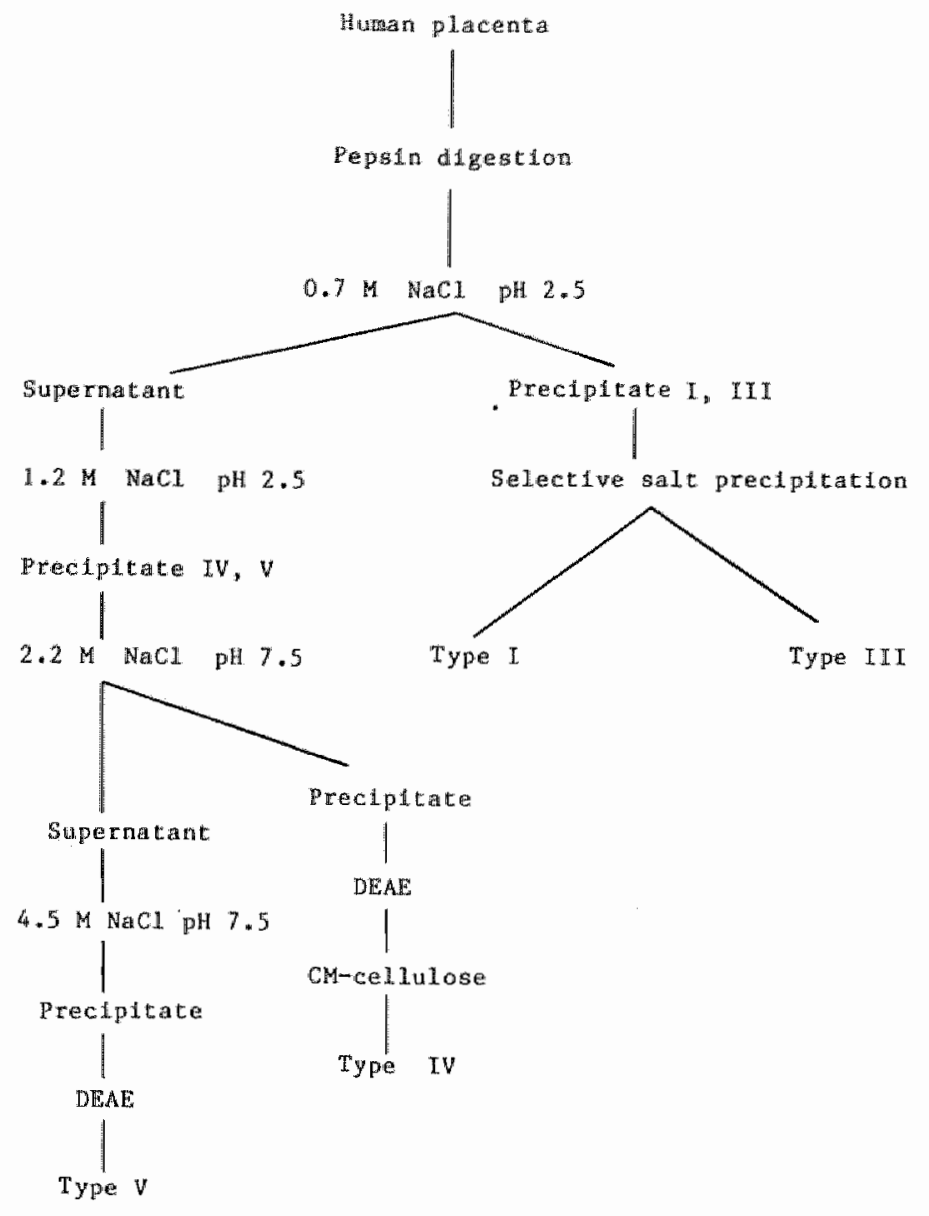

Figure I

\subsection{MATERIAL AND METHODS}

\subsubsection{Isolation and characterization of collagens}

Various collagen types were isolated from human placenta by limited pepsin digestion, fractionated by salt precipitation and chromatographic techniques modified from those of Miller \& Rhodes (16) as schematically represented in Fig. 1. The purity of the isolates was analyzed by sodium dodecyl sulphate $-5 \%$ polyacrylamide gel electrophoresis (17), followed by blotting onto nitrocellulose paper (18) and staining with aurodye (Janssen Life Science Products). 


\subsubsection{Preparation and isolation of hybridomas}

Female balb/c mice (TNO Zeist) were immunized with human placental type IV collagen (Sigma). The first injection (200 $\mu \mathrm{g}$ in complete Freunds adjuvant) was administered intraperitoneally. Booster injections of $100 \mu \mathrm{g}$ of type IV collagen (in incomplete Freunds adjuwant) were given intraperitoneally at three week intervals. At the fourth day after the last injection, spleen cells were isolated and fused in $50 \%$ polyethylene glycol with $\mathrm{Sp} 2 / 0$ myeloma cells, grown in Dulbecco's modified Eagle's medium, supplemented with $10 \%$ fetal calf serum. The cells were initially cultured in HAT medium to select for hybridomas and antibody production was detected by ELISA. To this end wells of a microtiter plate (polypropylene) were coated with $50 \mu \mathrm{l}$ of a solution of $5 \mu \mathrm{g} / \mathrm{ml}$ type IV collagen in $0.1 \mathrm{M}$ carbonate buffer $\mathrm{pH}$ 9.6. Supernatants of the tested wells were incubated overnight, followed by peroxidase labelled rabbit antimouse IgG antibodies. Peroxidase activity was detected by adding $O$-phenylene diamine substrate. Selected hybridomas were cloned by limiting dilution and expanded. Ascites was produced by intraperitoneal injection of hybridoma cells in Balb/c mice.

\subsubsection{Preparation of polyclonal antiserum}

Two rabbits were immunized intracutaneously with a solution of $1 \mathrm{mg} / \mathrm{ml}$ type IV collagen suspended in an equal volume of complete Freunds adjuvant. After two weeks a booster injection was given, followed by three more booster injections at two weekly intervals with the antigen in incomplete Freunds adjuvant.

\subsubsection{Immunological characterization}

Immunoreactivity of the monoclonal antibodies and the polyclonal antisera was tested by ELISA. Microtiter plates were coated with type I, III, IV and V collagen and the assay was carried out as described above.

Immunospecificity of the antibodies was tested by immunoblotting. SDS-polyacrylamide gel electrophoresis of beta-mercaptoethanol reduced and non-reduced type I and IV collagen were blotted onto nitrocellulose-paper. Immunoreactivity was visualized by peroxidase labelled rabbit anti mouse $\mathrm{lg}$ antibodies and diaminobenzidine as substrate. Isotyping of the monoclonal antibodies was performed in ELISA by coating microtiter plates with monoclonal antibody followed by isotype specific goat anti mouse IgG1, IgG2A, IgG2B and IgM. Finally the wells were incubated with peroxidase labelled rabbit anti goat Ig antibodies. 


\subsubsection{Tissues}

Samples of various human tissues were fixed in $40 \%$ neutral buffered formaldehyde, processed routinely and embedded in paraplast and sectioned at $4 \mu \mathrm{m}$. Tissue samples were also snap frozen in isopentane, quenched in liquid nitrogen. Fresh tissue samples were also collected from rat, mouse, rabbit, cow and dog and snap frozen. Frozen tissues were cryostat sectioned at $4 \mu \mathrm{m}$.

\subsubsection{Enzymes}

Immunoreactivity could only be demonstrated in paraffin sections through enzymatic digestion after deparaffinization and rehydration. To obtain an optimal procedure various enzymes were tested under varying conditions as summarized in Table 1.

\section{Table 1}

\begin{tabular}{|c|c|c|c|c|}
\hline Enxymac & $\begin{array}{l}\text { Range of } \\
\text { koncent ration }\end{array}$ & Range of buffer enondition & $\begin{array}{l}\text { Range of } \\
\text { incubation time } \\
\text { [hours }\end{array}$ & Temperature \\
\hline $\begin{array}{l}\text { Pepsian } \\
\text { (Bothringer) }\end{array}$ & $0.10 \% 0.5 \%$ & $\begin{array}{l}\text { HAc or HCl } \\
\text { pH } 1.0,3.0\end{array}$ & $1 / 2 \ldots 2$ & $\mathrm{RT} / 37^{\circ} \mathrm{C}$ \\
\hline $\begin{array}{l}\text { "rypsir } \\
\text { (Dirco) }\end{array}$ & $0.1 \% 0.5 \%$ & $\begin{array}{l}50 \mathrm{mH} \text { Trim } 1 \mathrm{Cl} \\
\text { pH } 70-8.5 \\
\text { (adj. } 2 \mathrm{NHCl}) \\
\mathrm{CaCH} 0.1-0.5 \%\end{array}$ & $1 / 41$ & $\mathrm{RT} / 37^{\circ} \mathrm{C}$ \\
\hline $\begin{array}{l}\text { Pronase } \\
\text { (Bochaliger) }\end{array}$ & $0.01 \%-0.05 \%$ & $\begin{array}{l}50 \mathrm{mM} \text { Tris- } \mathrm{HCl} \\
\mathrm{pH} 7.58 .0 \\
(\mathrm{wdl} .2 \mathrm{NHCl})\end{array}$ & ${ }^{1} / 41$ & $\mathrm{RT} / 37^{\circ} \mathrm{C}$ \\
\hline $\begin{array}{l}\text { Papainn } \\
\text { (Botenringer) }\end{array}$ & $0.1 \% \cdot 0.3 \%$ & $\begin{array}{l}50 \mathrm{~m} M \mathrm{NaAc} \text { buter } \\
0.2 \mathrm{MACl} \\
\mathrm{pH} 5.0 \cdots 6.0\end{array}$ & I, Af 1 & $\mathrm{RT} / 37^{\circ} \mathrm{C}$ \\
\hline $\begin{array}{l}\text { Hyahoronidase } \\
\text { (Comper Bhomeathioal) }\end{array}$ & $0.1 \% 0.5 \%$ & $\begin{array}{l}0.1 \mathrm{~N} \text { sodiun phosphate buther } \\
0.15 \mathrm{NaCl} \\
\text { pH } 4.560\end{array}$ & $1 / 2^{-2}$ & $\mathrm{RT} / 37^{\circ} \mathrm{K}$ \\
\hline
\end{tabular}

\subsubsection{Immunohistochemistry}

Frozen sections were fixed $20 \mathrm{~min}$ in acetone $\left(-20^{\circ} \mathrm{C}\right)$ and endogenous peroxidase activity was blocked in $0.3 \% \mathrm{H}_{2} \mathrm{O}_{2}$ in methanol, $20 \mathrm{~min}$, RT. After washing with PBS ( $3 \times 5$ min) monoclonal antibodies, undiluted supernatant or 1:400 diluted ascites (diluted in PBS with $1 \%$ BSA), were incubated ( 1 hr at RT) in a moist chamber. After washing with PBS the sections were incubated with peroxidase labelled rabbit anti mouse $\mathrm{Ig}$ antibodies (1hr, RT). After final washing with PBS, a diaminobenzidine- $\mathrm{H}_{2} \mathrm{O}_{2}$ substrate was used to visualize the immunoreactivity. Paraffin sections were deparaffinized, rehydrated and blocked for endogenous 
A.

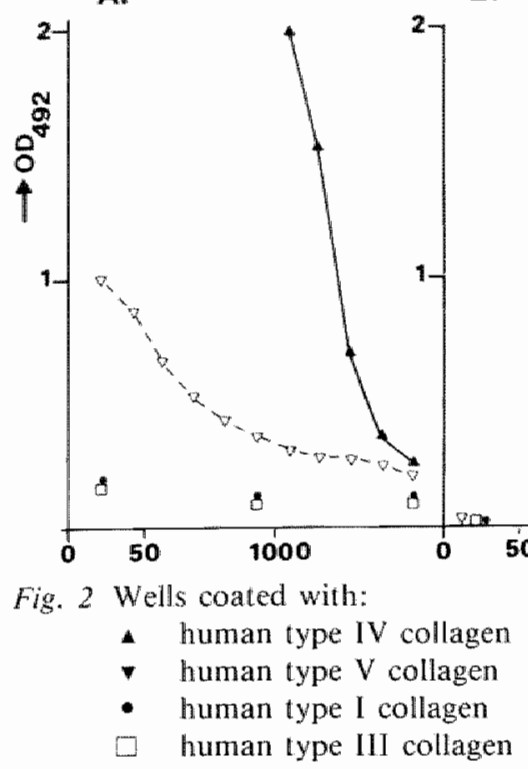

B.

$C$

Titrated with:

A. polyclonal antiserum to type IV collagen

B. monoclonal antibodies to type IV collagen (1042)

C. monoclonal antibodies to type IV collagen (1043)

peroxidase, followed by enzyme digestion, before applying the monoclonal antibodies. The further procedures were as for frozen sections.

\subsection{RESULTS}

\subsubsection{Polyclonal antiserum}

In the ELISA the polyclonal anti type IV collagen antiserum showed no crossreactivity with collagen types I and III and weak reactivity with type $V$ collagen (Fig. 2). In immunoelectroblotting experiments (Fig. 3) the polyclonal antiserum showed immunoreactivity with the various reduced and nonreduced type IV collagen bands, confirming its specificity. Immunohistochemical staining on frozen as well as on pepsin treated paraffin sections revealed a BM specific staining pattern. In tissue sections interstitial collagens were not detected nor could the $\mathrm{BM}$ specific staining be blocked by type $\mathrm{V}$ collagen, indicating the type IV collagen specificity of the immunoreactivity. On formalin fixed paraffin embedded sections immunoreactivity was only obtained after preincubation of the sections with pepsin or pronase (Fig. 


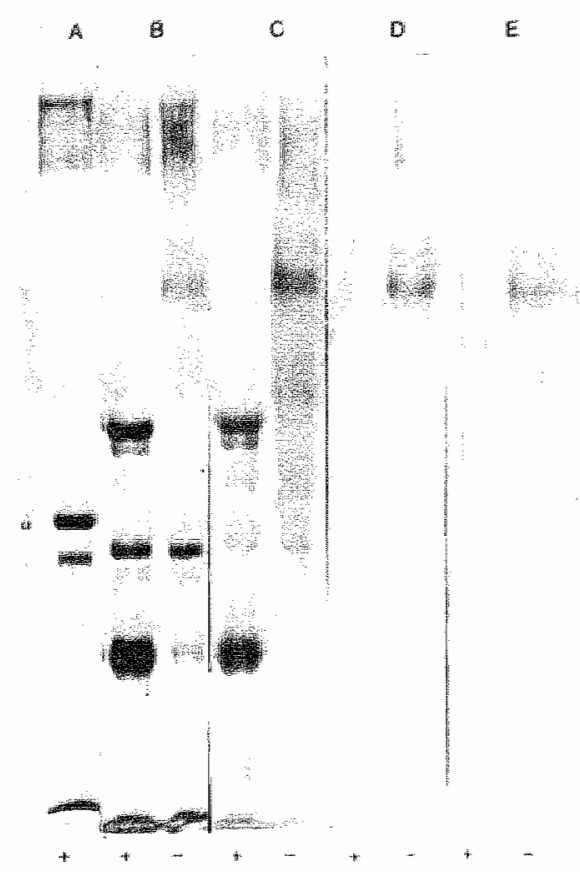

Fig. 3 A. human type I collagen stained with aurodye (lane 1)

B. human type IV collagen stained with aurodye (lane 2 and 3)

C. human type IV collagen reacted with polyclonal anti type IV collagen anti. serum (lane 4 and 5)

D. human type IV collagen reacted with monocional anti type IV collagen antibodies, 1042 (lane 6 and 7)

E. human type IV collagen reacted with monoclonal anti type IV collagen antibodies, 1043 (lane 8 and 9)

+ inclicates reduction with $\beta$-mercaptoethanol

- no reduction

$\alpha$ indicates the $100 \mathrm{kD}$ band of heat denaturated $\alpha \mathrm{l}(\mathrm{I})$

$4 \mathrm{~A}$ and $\mathrm{B}$ ) or with papain. This staining protocol was compatible with other fixation with formalin, Bouins', periodate-lysine-paraformaldehyde and picric-acid paraformaldehyde. Optimal conditions for pepsin treatment were $0.1 \%$ pepsin in $0.1 \mathrm{~N} \mathrm{HCl}, 30 \mathrm{~min}$ at $\mathrm{RT}$, for pronase $0,04 \%(\mathrm{w} / \mathrm{v})$, in $50 \mathrm{mM}$ Tris- $\mathrm{HCl}$ adjusted (with $2 \mathrm{~N} \mathrm{HCl}$ ) to pH $8.0,30 \mathrm{~min}$ at RT and for papain $0.2 \%(w / v)$ in $50 \mathrm{mM} \mathrm{NaAc}$ buffer with $0.2 \mathrm{M} \mathrm{NaCl}$ pH 5.5, 30 min RT (Table 2).

\subsubsection{Monoclonal antibodies}

Initial screening of the cloned hybridomas by ELISA yielded two type IV collagen reactive clones (1042 and 1043). Isotype determination showed that the monoclonal 


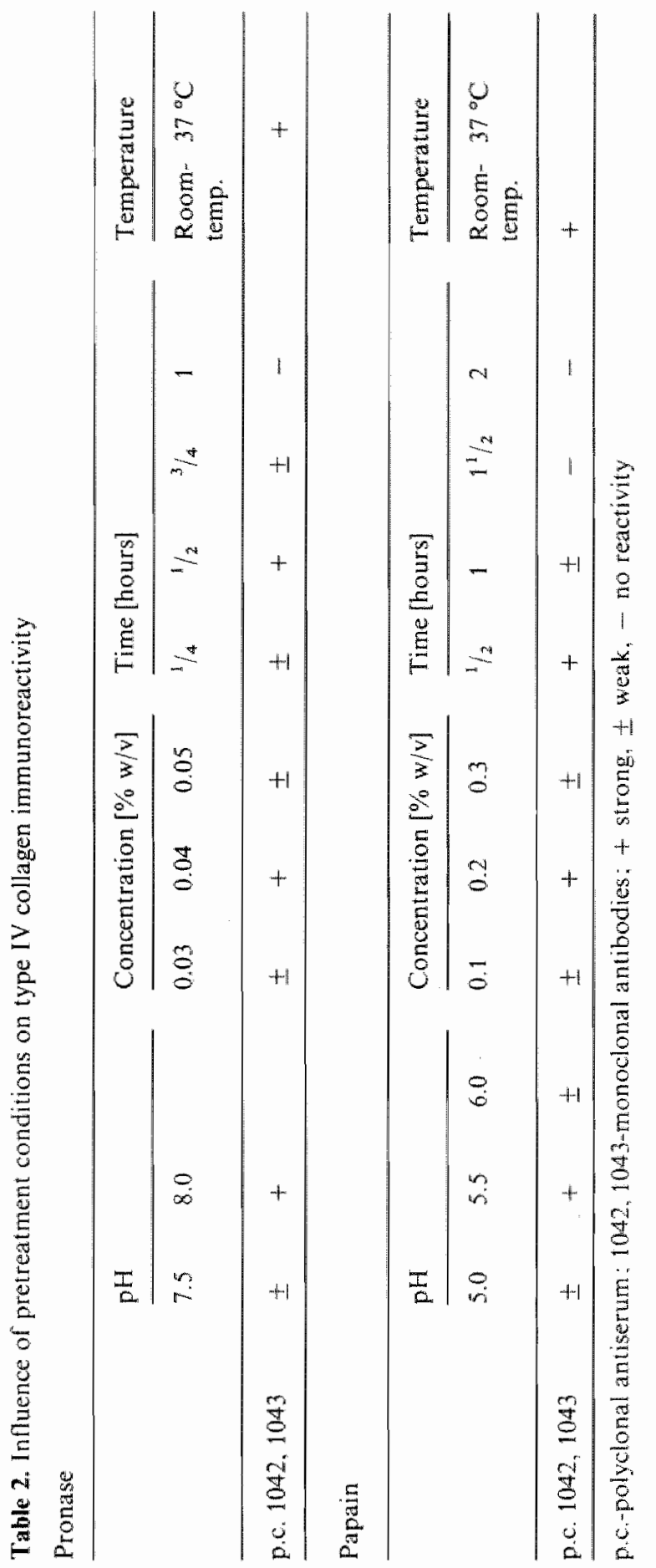



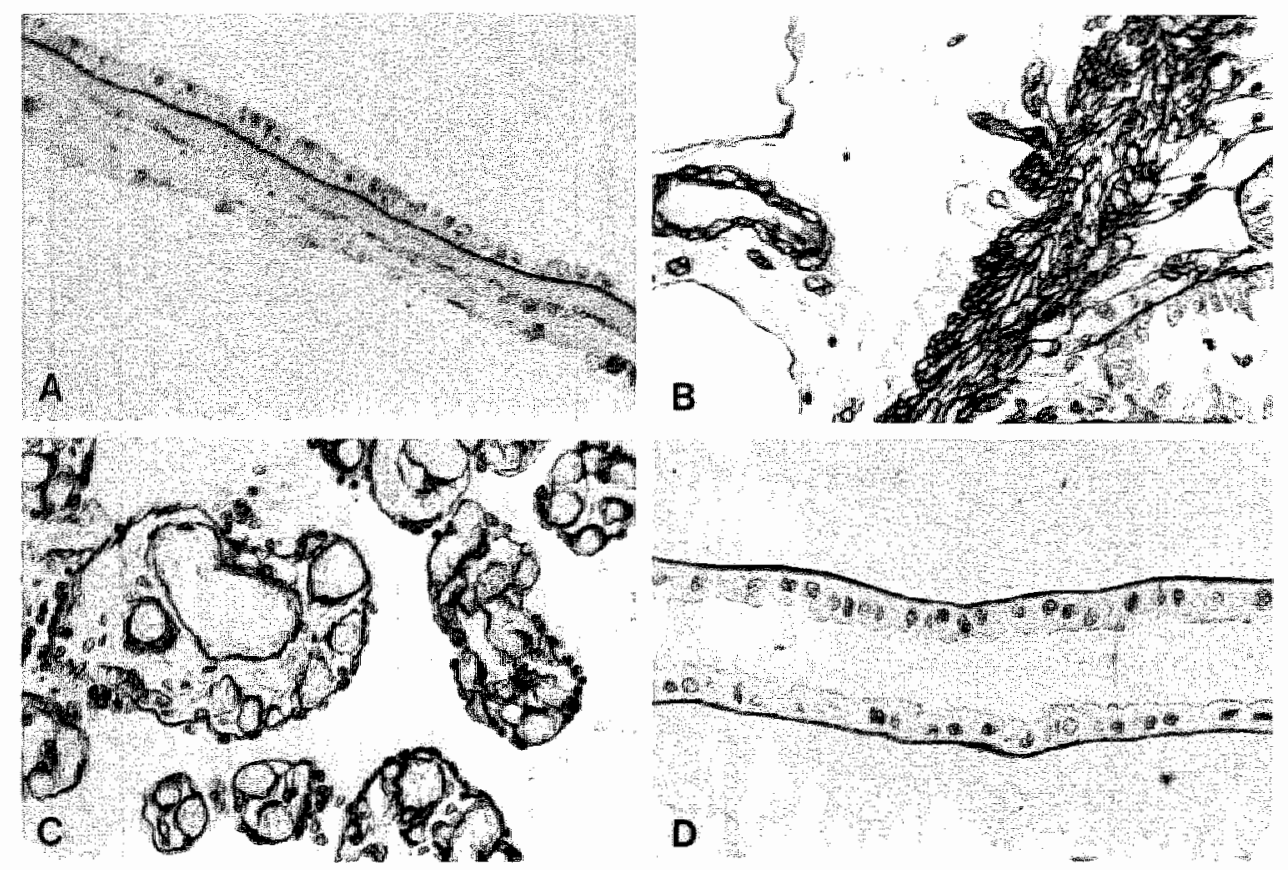

D
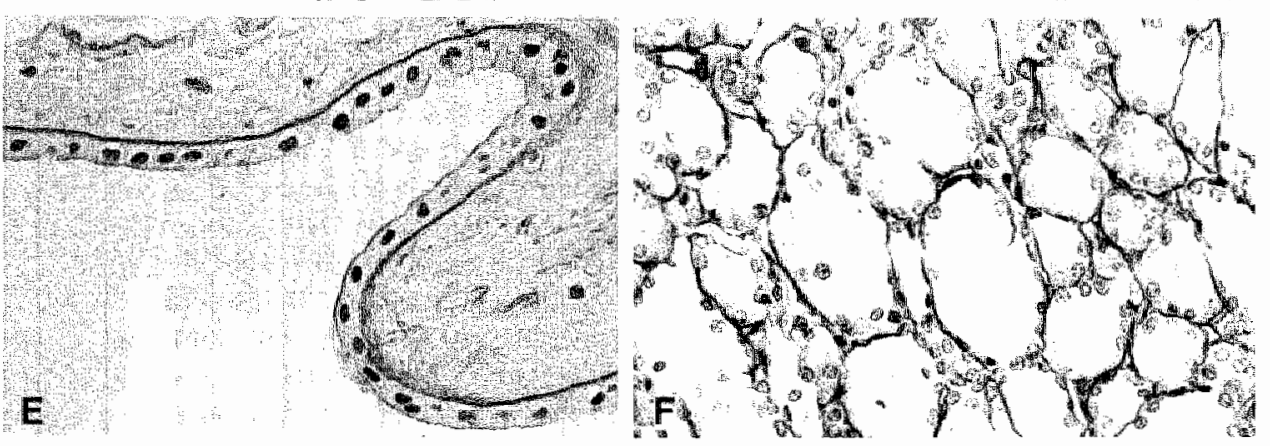

Fig. 4 Polyclonal antiserum to human type IV collagen (immunoperoxidase) applied to A human amnion (pepsin, $220 \mathrm{x}$ ) and $B$ normal human colon (pronase, $340 \mathrm{x}$ ). Monoclonal antibody (1042) to human type IV collagen (immunoperoxidase) applied $10 \mathrm{C}$ human placenta (pronase, $340 \mathrm{k}$ ) and $\mathrm{D}$ human amnion (papain, 340x). Monoclonal antibody (1043) to human type IV collagen (immunoperoxidase) applied to E human amnion (pronase, $340 \mathrm{x}$ ) and $\mathrm{F}$ human thyroid gland (pronase, $340 \mathrm{x}$ ). 
antibody 1042 is an IgG2B and 1043 an IgG1. Immunospecificity testing by ELISA to collagen types I, III, IV and $V$ confirmed that these monoclonal antibodies reacted only with type IV collagen (Fig. $2 \mathrm{~B}$ and $\mathrm{C}$ ).

In immunoblotting studies immunoreactivity could be detected in the high molecular weight region of non-reduced type IV collagen with both monoclonal antibodies. Reduced type IV collagen showed only one very weak band in the low molecular weight region with both monoclonal antibodies (Fig. $3 \mathrm{D}$ and E). No reactivity was found with other collagen types.

Immunohistochemical staining of frozen sections resulted in BM immunoreactivity, identical to the pattern obtained with the polyclonal antiserum. On formalin fixed paraffin embedded sections immunoreactivity was only obtained after enzyme pretreatment. Of the various enzymes tested only pronase and papain gave consistent results (Fig. 4 C-F). The effect of various conditions on the obtained immunoreactivity is summarized in table 2. Optimal conditions for pronase treatment were $0.04 \%(\mathrm{w} / \mathrm{v}$ ) of pronase in $50 \mathrm{mM}$ Tris- $\mathrm{HCl}$ adjusted (with $2 \mathrm{~N} \mathrm{HCl}$ ) to $\mathrm{pH}$ $8.0,30 \mathrm{~min}$ at $\mathrm{RT}$ and for papain $0.2 \%(\mathrm{w} / \mathrm{v})$ in $50 \mathrm{mMNaAc}$ buffer with $0.2 \mathrm{M}$ $\mathrm{NaCl}$ pH $5.5,30$ min RT.

\subsubsection{Species and organ specificity}

Human, rat, mouse, rabbit, bovine and canine tissues were studied for their BM immunoreactivity with the monoclonal antibodies 1042 and 1043. On frozen sections as well as paraffin sections immunoreactivity was obtained with human tissues only, the only exception being reactivity of 1042 with $\mathrm{BM}$ in rabbit tissues. Testing on an extensive panel of various human tissues showed immunoreactivity only with BM. Reactivity with interstitial collagens was notably absent. All epithelia expressed immunoreactivity to type IV collagen at the epithelia]-stromal interface. BM surrounded individual cells such as adipocytes, smooth and striated muscle, Schwann, and decidual cells and were demonstrated adjacent to lining cells such as endothelium, mesothelium, amnion and ependyma.

\subsection{DISCUSSION}

The $\mathrm{BM}$ has become a structure of high interest in relation to its role in normal development (19), neoplasia (20), and its function as a filtering barrier e.g. in the glomerulus (21). Immunocytochemistry has proven to be a valuable tool to study $B M$, essential requirements being specilic antibodies and reliable tissue processing procedures. The present report addresses both aspects of BM immunocytochemistry.

Polyclonal antisera to type IV collagen from various sources have been available for some time now and conditions for reliable immunocytochemical application on routinely processed tissues have been worked out by Barsky et al. (22). Our results 
largely confirm these findings. We found that in addition to pepsin, pronase and papain could also be used to obtain immunoreactivity in paraffin sections of tissues fixed in various fixatives.

The first monoclonal antibody to human type IV collagen, which was cross species reactive, was described by Sundarraj andWilson (23). Sakai et al. (24) produced a human specific monoclonal antibody to type IV collagen. None of these antibodies showed organ specificity. Foellmer et al. (25) raised two monoclonal antibodies to type IV collagen, one human specific and one cross-species reactive. Odermatt et al. (26) described two monoclonal antibodies, one of these showing immunoreactivity only with native human and bovine type IV collagen and the other being entirely human specific. These monoclonal antibodies showed some tissue specificity because neither the corneal BM nor Descemet's membrane reacted with the antibody. Scheinman and Tsai (27) also reported on a cross-species reactive monoclonal antibody. Only the mesangium and the subendothelial plane of the glomerular BM, the lens capsule and cornea were stained, indicating some degree of organ specificity. Our monoclonal antibodies 1042 and 1043 appeared to be almost completely human specific, the only exception being reactivity of 1042 with rabbit tissues. Organ specificity could not be detected, all the examined tissues showed immunoreactivity at the expected BM localization. An important finding was that both monoclonal antibodies could be applied to formalin fixed paraffin embedded tissue sections after preincubation with pronase or papain. Pepsin treatment, as described by Barsky et al. (22) was not effective. For all monoclonal antibodies the optimal tissue treatment protocol will depend on the characteristics of the involved epitope, which call for a specific protocol for each monoclonal antibody.

From our results and the data on anti human type IV monoclonal antibodies in the literature, we can conclude that although the basic structure of type IV collagen is rather similar in all species (as evidenced by the lack of species specificity of polyclonal antibodies) species specific epitopes occur. Species specific antibodies can be rather useful e.g. in cancer xenografting experiments in which these reagents may be used to detect the origin of BM (9-11). A similar conclusion can be drawn with regard to tissue- or organ specific epitopes. Although these appear to occur, it is likely that BM heterogeneity is more related to variations in heparan sulphate proteoglycan content and composition, and to the occurrence of organ specific components, of which the bullous pemphigoid antigen in epidermal BM might be an example (28). Others, however have claimed that the bullous pemphigoid antigen is more likely a cell membrane antigen than a BM antigen (29).

In conclusion, our results show that type IV collagen immunoreactivity can be reliably detected in a variety of routinely processed tissues with polyclonal as well as monoclonal antibodies, provided that appropriate enzymatic treatment is applied. The lack of tissue and organ specificity make the described monoclonal antibodies especially suitable for diagnostic use in histopathology. The species specificity is a rather useful characteristic in human-nude mouse xenotransplantation studies. 


\subsection{REFERENCES}

1. Martinez-Hernandez A. Amenta PS. The basement membrane in pathology. Lab Invesi 1983; 48 : 656-677.

2. Vracko R. Basal lamina scaffold: anatomy and significance for maintenance of orderly tissue structure. Am J Pathol 1974; 77; 314-338.

3. Mynderse LA, Hassel J, Kleinman HK, Martin GR, Martinez-Hernandez A. Loss of heparan sulphate proteoglycan from glomerular basement membrane of nephrotic rats. Lab Invest 1983; 48: 292-302.

4. Kefalides NA, Alper $R$, Clark C. Biochemistry and metabolism of basement membranes. Int Rev Cyt 1979; 61: 167-228.

5. Crouch E, Sage H, Bornstein P. Structural basis for apparent heterogeneity of collagens in human basement membranes: type IV procollagen contains two distinct chains. Proc Natl Acad Sci U.S.A. 1980; 77: 745-749.

6. Kühn K, Wiedemann $H$, Timpl R, Risteli J, Dieringer $H$, Voss $T$, Glanville $R W$, Macromolecular structure of basement membrane collagens. Identification of $7 \mathrm{~S}$ collagen as a crossbinding domain of type IV collagen. FEBS Lett 1981; 125: 123-128.

7. Timpl $R$, Wiedemann $H$, Van Delden $V$, Furthmayer $H$, Kühn $K$. A network model for the or ganization of type IV collagen molecules in basement membranes. Eur $\$ Biochem 1981; 12: 203-211.

8. Hay ED. Role of basement membranes in development and differentiation. In: Biology and chemistry of basement membranes. 1978 Academic Press. New York, pp. 119-136.

9. Damjanov I, Damjanov N, Knowless BB, Engvall E. Origin of laminin in the extracellutar matrix of human tumor xenografts in nude mice. Virchows Arch (Cell Pathol) 1985; 49:45-52.

10. Holmstrup P. Sudies on the deposition of laminin and type IV collagen in human oral mucosa transplanted to nude mice. Acta Path Microbiol Immunol Scand Sect A 1985; 93: 1-8.

11. Havenith MG, Simon REM, Arends $J W$, Verstijnen $C$, Cleutjens $J$, Bosman $\mathrm{FT}$. Origin of basement membrane type IV collagen in xenografted human epithelial tumor cell-lines. Submitted to Virchows Arch (Cell Pathol).

12. Albrechtsen R, Nielsen M, Wever U, Engvall E, Ruoslahti E. Basement membrane changes in breast cancer detected by immunohistochemical staining for laminin. Cancer Res 1981; 41 : 5076-5081.

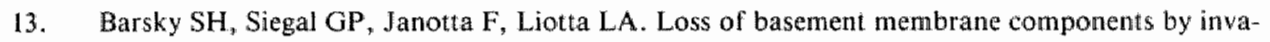
sive tumors but not by their benign counterparts. Lab Invest $1983: 49: 140-147$.

14. Miettinen M, Foidart JH, Ekblom P. Immunohistochemical demonstration of laminin, the major glycoprotein of basement membranes, as an aid in the diagnosis of soft tissue tumors. Am I Clin Pathol 1983; 79: 306-311.

15. Ogawa $K$, Oguchi $M$, Yamabe $H$, Nakashima $Y$, Hamashima $Y$. Distribution of collagen type IV in soft tissue tumors. Cancer 1986; 58: 269-277.

16. Miller EJ, Kent Rhodes R. Preparation and characterization of the different types of collagen. Methods in Enzymology: 1982, vol. 82, Academic Press lnc. pp. 32-64.

17. Laernmli UK. Cleavage of structural proteins during the assembly of the head of the bacteriophage T4. Nature 1970; $227: 680-685$.

18. Towbin $\mathrm{H}$, Stachelin $\mathrm{T}$, Gordon $J$, Electrophoretic tr ansfer of proteins from polyacrylamide gels to nitrocellulose sheets: procedure and some applications. Proc Nail Acad Sci U.S.A. 1979; 76 : $4350-4354$.

19. Sanders EX. Recent progress towards understanding the roles of the basement membrane in development. Can J Biochem Cell Biol 1983; 61: 949.956.

20. Bosman FT, Havenith MG, Cleutjens JPM. Basement membranes in cancer. Ultrastruct Pathol 1985; 8: 291-304.

21. Kanwar YS, Farquhar MG. Anionic sites in the glomerular basement membrane. In viwo and vitro localization tho the laminae rarae by cationic probes. J Cell Biol 1979; 81: 137-153.

22. Barsky SH, Rao NC, Restrepo C, Liotta LA. Immunocytochemical enhancement of basement membrane antigens by pepsin: applications in diagnostic pathology. Am J Clin Pathol 1984; 82: 191-194. 
23. Sundarraj $\mathrm{N}$, Willson 1 . Monoclonal antibody to thuman basement membrane collagen type IV. Immunology $1982: 47: 133-140$.

24. Sakai LY, Engwall E. Hollister DW, Burgeson RE. Production and characterization of a monoclonal antibody to thuman type IV collagen. Am J Pathol 1982; 108: 310-318.

25. Foxllner HO, Madri JA, Furthmayr H. Monodonal antibodies to type IV collagen: probes for the study of structure and function of basement membranes. Lab Invest 1983; 48: 639-649.

26. Odermatt BF, Lang AB, Rutner JR, Winterhalter KH, Trueb B. Monoclonal antibodies to human type IV collagen: useful reagents to demonstrate the heterotrimeric narure of the molecule. Proc Nall Acad Sei U.S.A. 1984; 81: 7343-7347.

27. Scheinman JI, Tsai C. Monoclonal antibody to type IV collagen with selectiwe basement membrane localization, Lab Invesit 1984; $50: 101-112$.

28. Woodley DT, O'Keefe EJ, Reese MJ, Mechanic GH, Briggaman RA, Gammon WR. Epidermolysis bullosa acquisita antigen, a new major component of the cutaneous basement membrane, is a glycoprotein with collagenous domains. $J$ Invest Dernatol 1986; 86: 668-672.

29. Horiguchi $Y$, Imamura $S$. Discrepancy between the localization of in wivo bound immunoglobulins in the skin and in vitro binding sites of circulating anti-BMZ antibodies in bullous pemphigoid: Immuno-electron microscopic studies. II Invest Dermatol 1986; 87: 715-719. 


\section{CHAPTER 3}

\section{Origin of basement membrane type IV collagen in xenografted human epithelial tumor cell-lines. *}

\subsection{INTRODUCTION}

Basement membranes ( $\mathrm{BM}$ ), which connect epithelia with the underlying stroma, are composed of macromolecules such as type IV collagen $(1), \operatorname{laminin}(2,3)$ and heparan sulphate proteoglycan (4). Using specific antibodies to one or more of these constituents it has been shown that in many carcinomas a discontinuous BM is deposited at the epithelial-stromal interface. It has been suggested that the ability of cancer cells to generate a BM may be associated with invasive and metastatic behavior (5-10) and may be correlated with patient survival (11). It is generally assumed that epithelial BM are at least partly a product of the epithelial cells. Several investigators have demonstrated that in vitro epithellal tumor cells may continue to produce BM components. Experimental data concerning BM origin in neoplasms in vivo is very scanty. Recently, Damjanov et al. (12) studied the extracellular matrix of human tumor xenografts in mude mice using monoclonal anti-laminin antibodies, exclusively reactive with human laminin, and polyclonal anti-Jaminin antibodies reacting with human as well as with murine laminin. In many of their xenografts, tumoral BM laminin appeared to be of human as well as murine origin. They concluded that laminin in the extracellular matrix of xenografted tumors is at least partly of stromal origin. In this report we describe a similar study with a cross-species reactive polyclonal anti-type IV collagen antiserum and two human specific type IV collagen reactive monoclonal antibodies in normal and neoplastic human epithelial cells in vivo and in vitro.

\subsection{MATERIAL AND METHODS}

\subsubsection{Tissues}

Human cell-lines derived from a colonic adenocarcinoma (5583-S), from transformed amnionic epithelium (WISH), and from an oral epidermoild carcinoma (KB) were used for this study. The characteristics of the 5583-S cell-line are described extensively elsewhere (13). The WISH and KB cell--ines were obtained from the American Type Culture Collection (ATCC), the characteristics of these cell lines are described by Hayflick and Eagle $(14,15)$. Cells were cultured in Dulbecco's modi-

* Haverith MG, Simon REM, Arends JW, Verstijnen C. Cleutjens JPM, Bosman FT

Submitted to Virchows Arch (Cell Pathol) 
fied Eagle's medium (DMEM, Flow Laboratories) supplemented with $10 \%$ fetal calf serum (FCS, Sera Lab).

Cell culturing in collagen lattices was performed under conditions described by Nusgens (16). Instead of rat type I and III collagen, human type I and III collagen isolated from placenta were used as described elsewhere (17). For histological evaluation the collagen lattices were processed as described for the tissue samples.

All tumor cell lines were xenografted in nude mice (NMRI nu/nu supplied by Zentral Institut für Versuchstiere, Hannover, FRG) and nude rats (CD $1 \mathrm{nu} / \mathrm{nu}$ supplied by Charles River, Sulzfeld, FRG) by injecting tumor cell suspensions $\left(1.5 \times 10^{6}\right.$ cells) subcutaneously. After a period of $2-6$ weeks solid tumors of $0.5-1 \mathrm{~cm}$ in diameter were obtained.

Small fragments of normal colonic mucosa, including muscularis mucosae, were carefully removed from colonic carcinoma resection specimens and xenografted into nude mice (NMRI nu/nu) as described extensively elsewhere (18). Xenografts were removed after 14 days. Samples of the primary tumor of cell-line 5583-S, of the xenografts and of the collagen lattice cultures were snap frozen in isopentane quenched in liquid nitrogen and stored at $70^{\circ} \mathrm{C}$ and/or fixed in $10 \%$ neutral buffered formalin and further embedded in paraplast.

\subsubsection{Antibodies}

Details of the preparation and characterization of the polyclonal and monoclonal antibodies have been described extensively elsewhere (17). Briefly, polyclonal antibodies to type IV collagen were raised in rabbits by immunizing with human placental type IV collagen. The titer of the antiserum was monitored by solid phase enzyme immunoassay (ELISA) and the specificity of the antiserum was analyzed by SDS-PAGE followed by immunoblotting as well as staining of various tissues. Monoclonal antibodies to type IV collagen were raised by immunizing $\mathrm{Balb} / \mathrm{c}$ mice with human type IV collagen. Three days after the final immunization mice were sacrificed and spleen cells were fused with $\mathrm{Sp} 2 / \mathrm{O}$ cells. Supernatants were tested for type IV collagen immunoreactivity by ELISA. Cross-reactivity with interstitial collagen (type I and III), type V collagen and laminin was excluded by ELISA. Two type IV collagen reactive hybridomas (1042 and 1043) were obtained and cloned by limiting dilution until monoclonal. Species specificity of these monoclonal antibodies was tested by immunohistochemistry on tissue sections of human as well as various murine lissues.

\subsubsection{Immunoblotting of culture supernatants}

Supernatants of 5583-S, WISH and KB cells were precipitated with $4 \mathrm{M} \mathrm{NaCl}$, dissolved in and dialyzed against SDS-sample buffer and run on a $5 \%$ SDSpolyacrylamide gel (19), followed by blotting onto nitrocellulose membranes (20). 


\subsubsection{Immunohistochemistry}

In order to expose the antigenic sites, paraffin sections of tissues were pretreated with pronase (Boehringer, $400 \mu \mathrm{g} / \mathrm{ml}$ in $50 \mathrm{mM}$ TRIS- $\mathrm{HCl}$ buffer, $\mathrm{pH} 8.0$, for 30 minutes at $37^{\circ} \mathrm{C}$ ) when monoclonal antibodies were applied, or with pepsin (Boehringer, $0.1 \mathrm{mg} / \mathrm{ml}$ in $0.01 \mathrm{~N} \mathrm{HCl}, 30$ minutes at $37^{\circ} \mathrm{C}$ ) for the polyclonal antiserum. On frozen sections the antibodies could be employed without enzymatic pretreatment. Sections were incubated for one hour with the primary antibodies and subsequently with peroxidase-labeled rabbit anti-mouse Ig or peroxidase labeled goat anti-rabbit Ig (Dakopatts, Copenhagen, Denmark) for the monoclonal and polyclonal antibodies respectively. After each incubation, sections were washed with PBS $(3 \times 5 \mathrm{~min})$. Immunoreactive sites were visualized with diaminobenzidine. Finally, the sections were lightly counterstained with Mayer's haematoxylin.

\subsection{RESULTS}

\subsubsection{Antibody specificity}

By ELISA the polyclonal anti-type IV collagen antiserum did not react with collagen types I and III and showed only a slight reaction with type V collagen (Fig. 1A). Under immunohistochemistry conditions, however, the antiserum only detected type IV collagen, as indicated by solid phase immunoadsorption of the antiserum with type $V$ collagen. Reactivity with type $I, I I I$ and $V$ could not be detected with the monoclonal antibodies (Fig.1 B and C). In immunoelectroblotting experiments the polyclonal antiserum expressed immunoreactivity with several reduced and non reduced type IV collagen bands, in the same pattern as the aurodye stain of the reduced and non reduced type IV collagen (Fig. 2 lanes 2-5). However, both monoclonal antibodies showed identical immunoreactivity with a single band in the high molecular region of non-reduced type IV collagen and very weak immunoreactivity with a single band in the low molecular region (Fig. 2 lanes 6-9).

Immunohistochemical experiments further substantiated the specificity of these antibodies. On a wide variety of human tissues both polyclonal and monoclonal antitype IV collagen antibodies reacted exclusively with $\mathrm{BM}$ in an identical pattern. On sections of normal tissues from various other species (including Balb/c and NMRI nu/nu mice) polyclonal anti-type IV collagen antibodies showed a similar pattern of immunoreactivity. The two monoclonal antibodies, however, did not show any reactivity with tissues from these species.

\subsubsection{Type IV collagen labelling in primary colonic carcinomas and cancer cell lines}

In the primary tumor, from which the 5583-S cell-line was derived, polyclonal as well as monoclonal antibodies localized in BM, which were deposited extensively, but 
A.

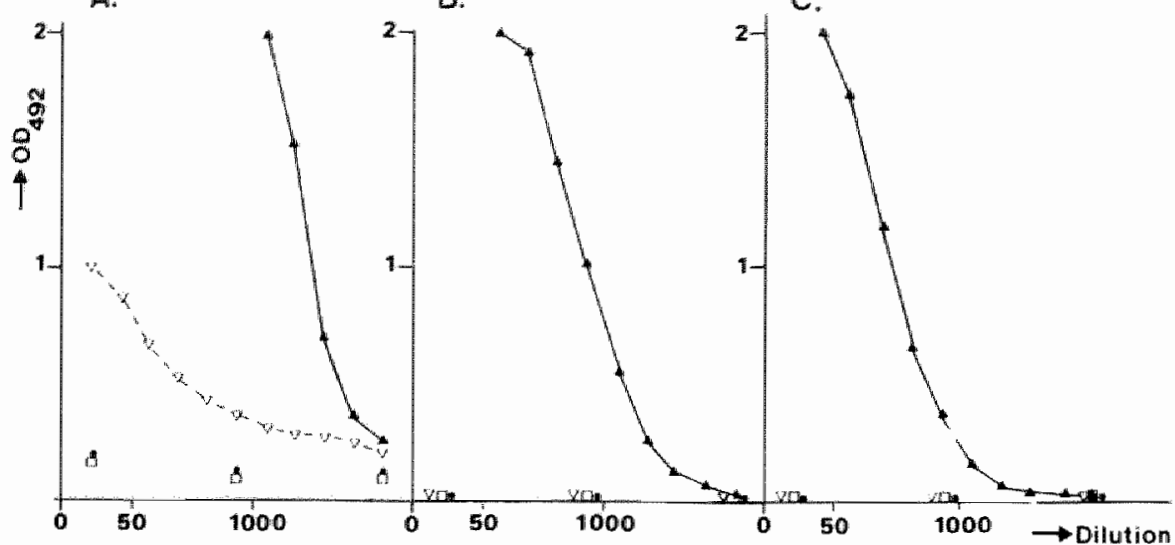

Fig. 1. ELISA testing of reactivity of anti-type IV collagen antibodies with

* human type I collagen

- human type III collagen

- human type IV collagen

D. human type $V$ collagen

A. rabbit polyclonal anti type IV antiserum

B. 1042, mouse monoclonal anti human type IV collagen antibody

C. 1043, mouse monoclonal anti human type IV collagen antibody

discontinuously and irregularly at the epithelial-stromal interface (Fig. 3). Immunohistochemical studies of 5583-S cells grown in artificial collagen lattices did not reveal any reactivity with the polyclonal or with the monoclonal anti-type IV collagen antibodies (Fig. 4).

Immunoblots of the precipitated tissue culture supernatants of 5583-S cell-line lacked any immunoreactivity with antibodies to type IV collagen, whereas pro $\alpha 1-$ and pro $\alpha 2$-chains of type IV collagen were detected in supernatants of WISH and KB cell-lines by this method (data not shown).

WISH and $\mathrm{KB}$ cells cultured in collagen lattices showed extensive granular intracytoplasmic and/or pericellular immunoreactivity for type IV collagen with polyclonal as well as monoclonal antibodies, BM like structures could not be identified (Fig 5).

\subsubsection{Type IV collagen labelling in xenografts}

In xenografts of normal human colonic mucosa polyclonal anti type IV collagen antibodies reacted with epithelial as well as endothelial and smooth muscle BM. All BM were highly regular and continuous. A similar pattern of immunoreactivity was seen with monoclonal anti-type IV collagen antibodies.

In xenografts of 5583-S, WISH, and KB cells immunohistochemical studies with 


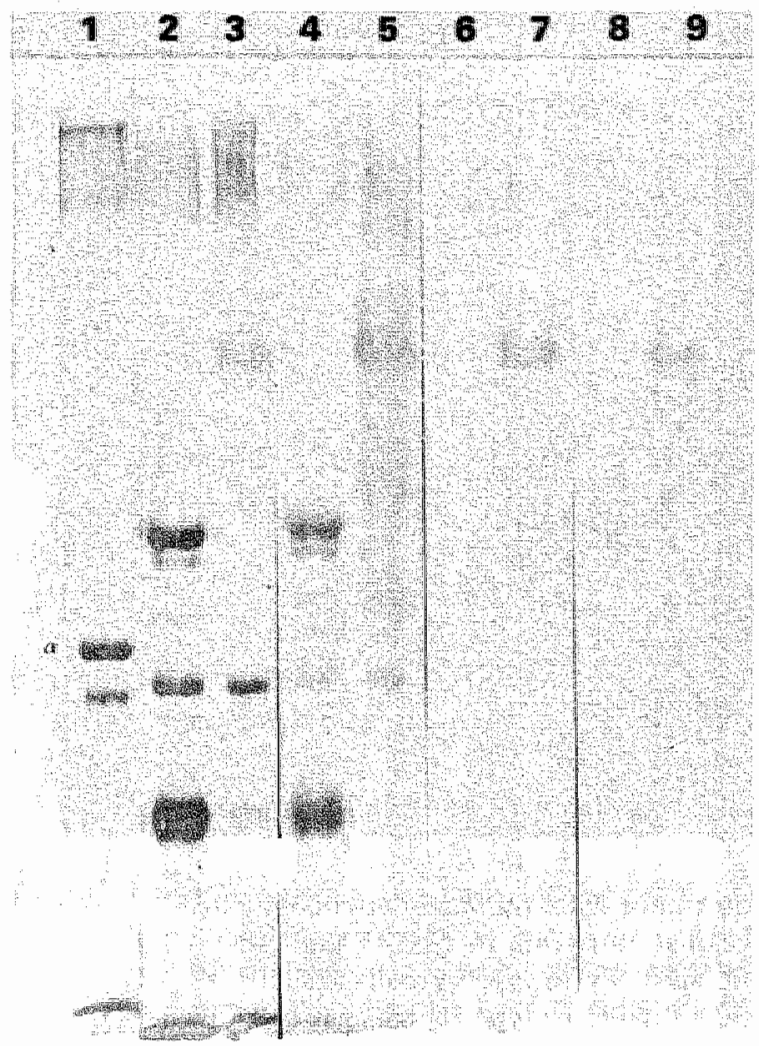

Fig. 2. Western blot of SDS-PAGE separated collagens.

Lane 1 Reduced human type I collagen stained with Aurodye

Lane 2 and 3 Reduced and non-reduced human type IV collagen stained with Aurodye

Lane 4 and 5 Reduced and non-reduced human type IV collagen reacted with polyclonal anti-type IV collagen

Lane 6 and 7 Reduced and non-reduced human type IV collagen reacted with monoclonal 1042

Lane 8 and 9 Reduced and non-reduced human type IV collagen reacted with monoclonal 1043 heat denatured alpha-1 (l), $100 \mathrm{kD}$.

polyclonal anti-type IV collagen antibody showed reactivity with epithelial as well as vascular BM. The epithelial BM were irregular and discontinuous, many tumor cell nests lacking a BM altogether (Fig. 6A). In 5583-S xenografts, however, both monoclonal antibodies (Fig. $6 \mathrm{~B}$ and $\mathrm{C}$ ) did not show any reactivity for type $1 \mathrm{~V}$ collagen. In WISH and KB xenografts BM like reactivity for type IV collagen with the monoclonal antibodies could be demonstrated clearly (Fig. 7 A and B). BM of vascular structures in the xenografts, however, did not react with the monoclonal antilype IV collagen antibodies. 

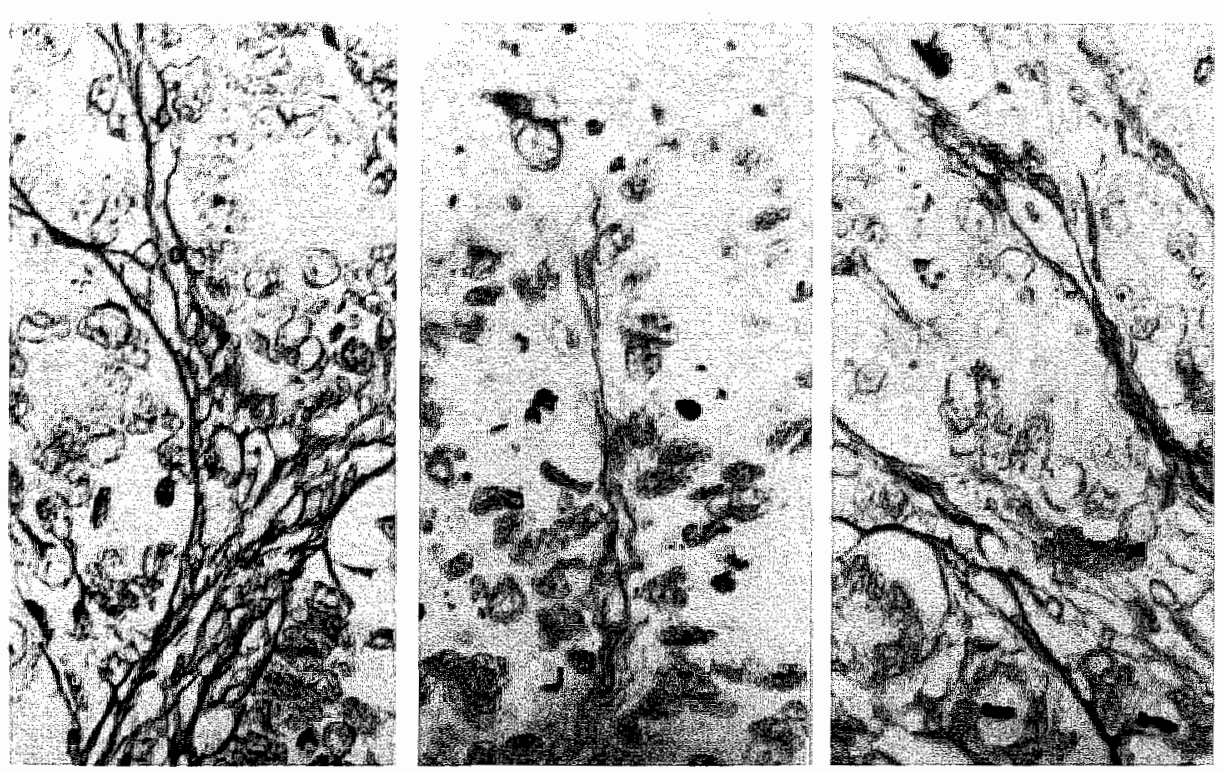

Fig. 3. Paraffin sections of the primary tumor 2983 (immunoperoxidase 340x)

A. cross species reactive polyclonal antiserum to type IV collagen

B. monoclonal human specific antibody to type IV collagen (1042)

C. monoclonal human specific antibody to type IV collagen (1043)

All sections show type IV collagen immunoreactivity at the epithelial-stromal border and perivascularly.

\subsection{DISCUSSION}

Xenografts of human tissues in nude mice offer an experimental model to study the in vivo interaction of normal or neoplastic epithelial cells with mesenchymal stromal elements. When antibodies which discriminate between human and murine BM components are employed in immunohistochemical studies, the host or graft origin of these components can be determined. In that model Holmstrup (21) examined the presence of laminin and type IV collagen in BM of normal human oral mucosa, transplanted into nude mice. In this study polyclonal antibodies against laminin and type IV collagen reacted equally well with vascular and epithelial BM whereas human specific monoclonal antibodies reacted primarily with vascular BM and only weakly with epithelial BM. Holmstrup concluded that under these conditions oral mucosal cells are able to participate in the formation of $\mathrm{BM}$ at the epithelial/stromal interface and that the vessel supply of the transplants is of both human and murine origin. Demarchez et al (22) studied revascularization of human skin transplants onto nude mice, applying murine and human specific antibodies to type IV collagen 

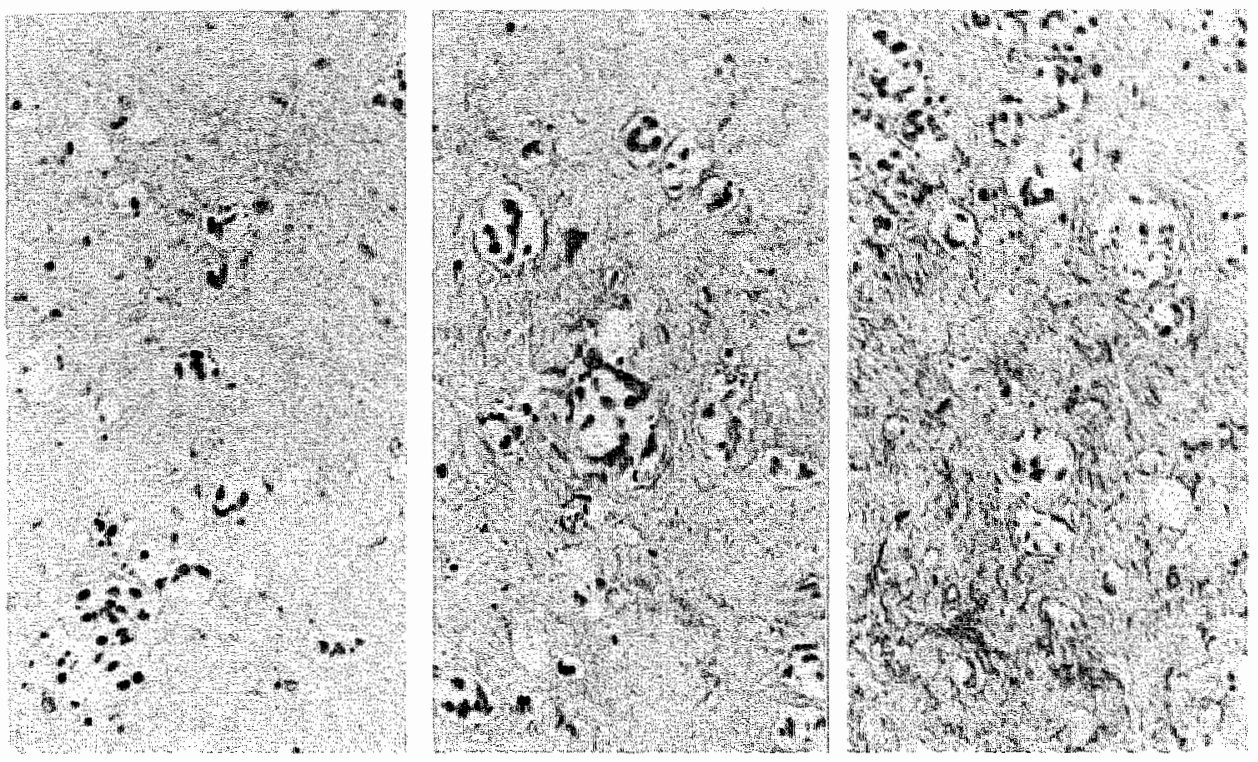

Fig. 4. Paraffin sections of tumor cell-line 5583 cultured in artificial collagen lattices (immunoperoxidase 225x)
A. cross species reactive polyclonal antiserum to type IV collagen
B. monoclonall human specific antibody to type IV collagen (1042)
C. monoclonall human specific antibody to type IV collagen (1043)
No immunoreactivity to type IV collagen is apparent

and HLA-DR antigens for identification of the origin of the BM and endothelium. A shift from human to murine endothelium and a subsequent change from human to mouse type IV collagen in the subendothelium BM was found. Kühl et al found in a coculture of mouse myoblasts with chicken fibroblasts deposition of type IV collagen of chicken origin in the BM around mouse myoblasts (23). Damjanov et al. (12) performed experiments with nude mice xenografts of a lung adenocarcinoma and a yolk sac carcinoma, known to produce cell associated laminin in vitro and a hepatoblastoma and a hepatocellular carcinoma, lacking this characteristic. Using cross-species reactive as well as human specific anti-laminin antibodies the former xenografts were shown to contain pericellular laminin of both human and murine origin, whereas the Jatter xenografts only demonstrated pericellular laminin of mouse origin. Vascular BM only contained laminin of murine origin.

From these findings it can be concluded that BM in epithelial as well as non epithelial tissues are not exclusively the product of the adjacent cell. Connective tissue elements most likely also contribute to the deposition of the BM. Against this background we studied the origin of BM in human tumor cell-lines, xenografted into 

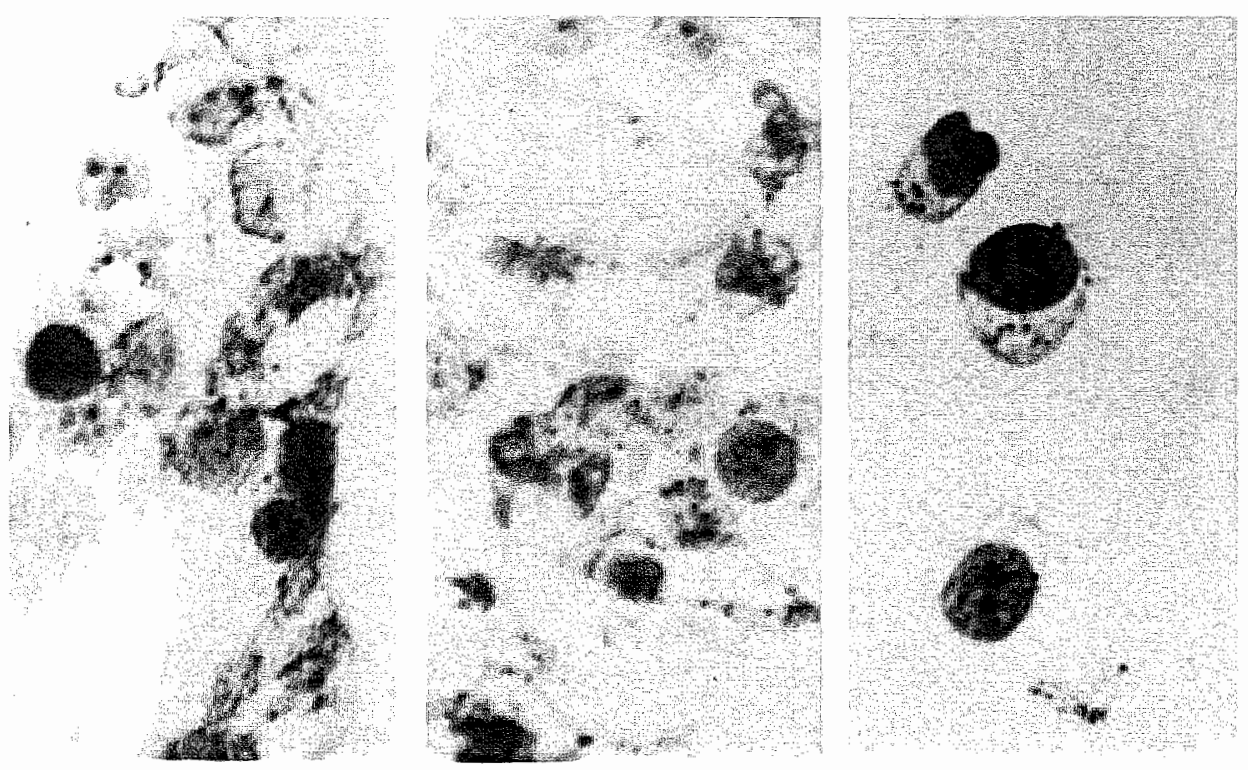

Fig. 5. Frozen sections (A and B) and cytospin preparation (C) of WISH and KB cells (immunoperoxidase $900 \mathrm{x}$ ).

$A+B$. Cross-species reactive polyclonal antiserum to type IV collagen.

C. Monoclonal human specific antibodies to type IV collagen.

Granular intracytoplasmatic staining.

nude mice and rats, using cross-species reactive polyclonal antibodies as well as human specific monoclonal antibodies to type IV collagen. We observed type IV collagen immunoreactivity in $\mathrm{BM}$ of the extracellular matrix of a primary colonic carcinoma and of the xenografted cell-line (5583-S) using cross-species reactive polyclonal anti-type IV collagen antiserum. However, with human specific monoclonal anti-type IV collagen antibodies immunoreactivity was only detected in the primary colonic carcinoma but not in the xenograft. In xenografted normal human colonic mucosal fragments the BM of epithelium, endothelium and smooth muscle did react with polyclonal as well as monoclonal antibodies. Neither by immunoblotting of the supernatant nor by immunohistochemistry could we detect in vitro production of type IV collagen by 5583-S cells. In vitro production of type IV collagen, however, was found in WISH and KB cells by these methods. In xenografts of WISH and KB cells polyclonal as well as monoclonal antibodies did stain BM like structures, vascular BM showed only immunoreactivity with polyclonal antibodies. In xenografts of 5583-S cells BM therefore lack a human type IV collagen epitope, which can be detected in primary cancer tissues as well as in the human colonic mucosa xenografts, which included stromal elements. Tumor cells which do produce type IV collagen 

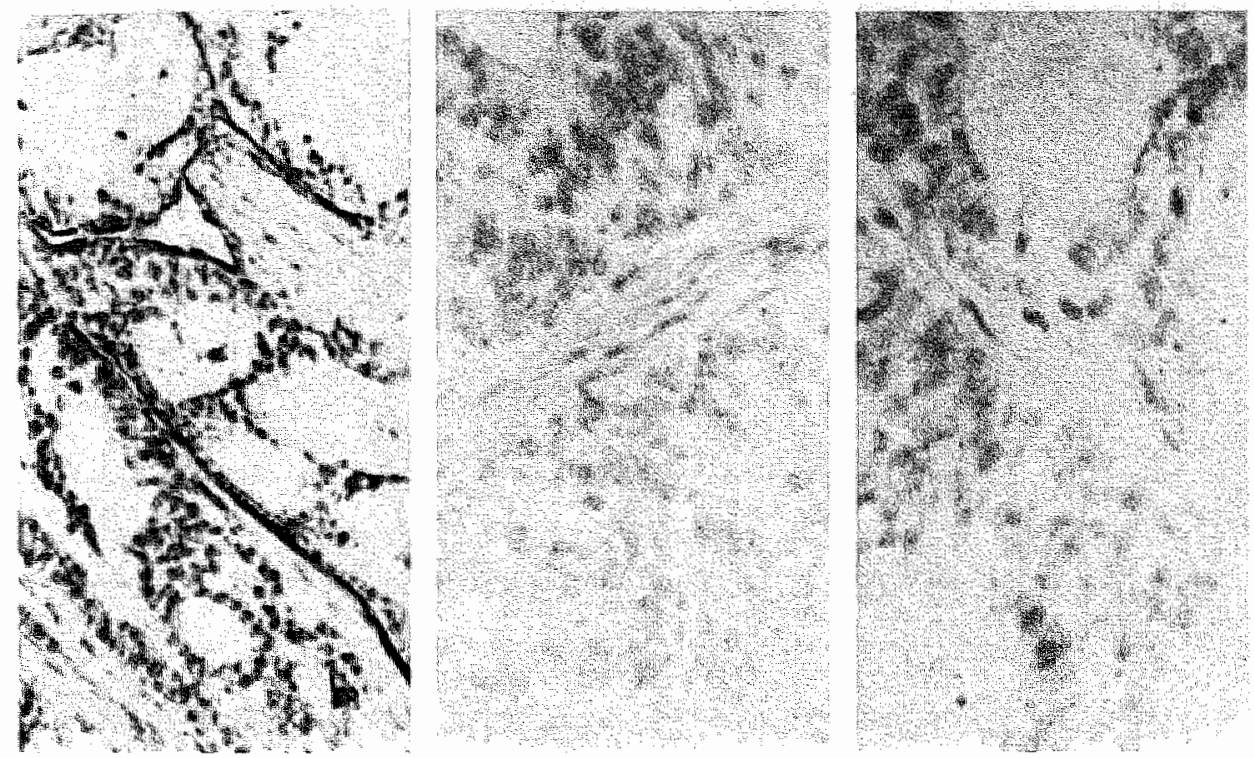

Fig. 6. Frozen sections of xenografted tumor derived from tumor cell-line 5583 (immunoperoxidase $340 x$ ).

A. cross species reactive polyclonal antiserum to type IV collagen

B. monoclonal human specific antibody to type IV collagen (1042)

C. monoclonal human specific antibody to type IV collagen (1043)

The human specific monoclonal antibodies to type IV collagen do not react with type IV collagen in the tumor.

in vitro, however, also deposit human type IV collagen in a xenograft. The most obvious explanation for these findings would be that in tumors which lack the ability to produce BM components in vitro, but do show deposition of BM in vivo, this element of the extracellular matrix is derived from the mesenchymal stroma. Two alternative explanations should be considered. Firstly, neoplastic cells might produce an abnormal type IV collagen molecule, which lack the human specific epitope. The reactivity of the primary tumors with the monoclonal antibodies argues against this possibility. Secondly, under transplantation conditions the expression of the human specific epitope might be lost. The persistence of the reactivity in the normal colonic mucosa xenografts, however, rules out this explanation. It is conceivable that in cancer tissues in the in vivo situation mesenchymal stroma regulates the production of BM components by neoplastic cells. Coculturing experiments of human carcinoma cells with murine and human fibroblasts might further clarify whether or not mesenchymal stroma is involved in the regulation of the production of BM constituents and their assembly to a structurally recognizable BM in vitro. 
A

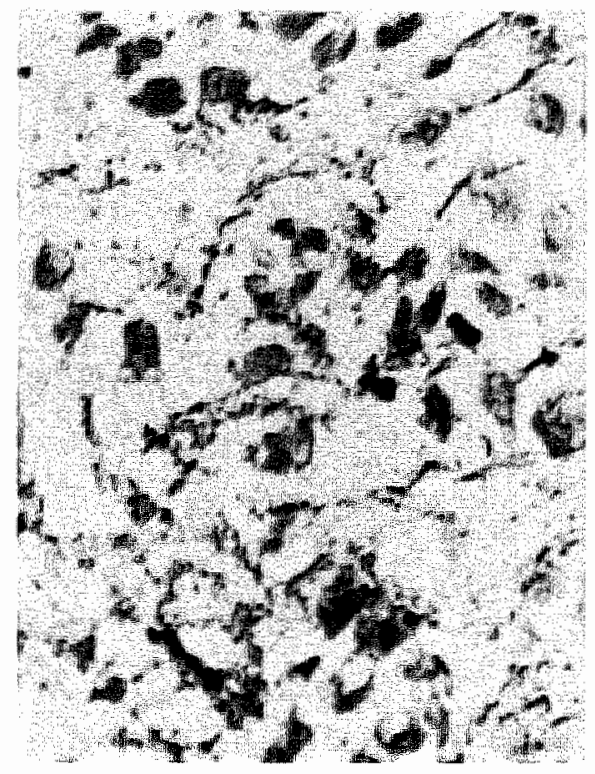

$\mathrm{Bi}$

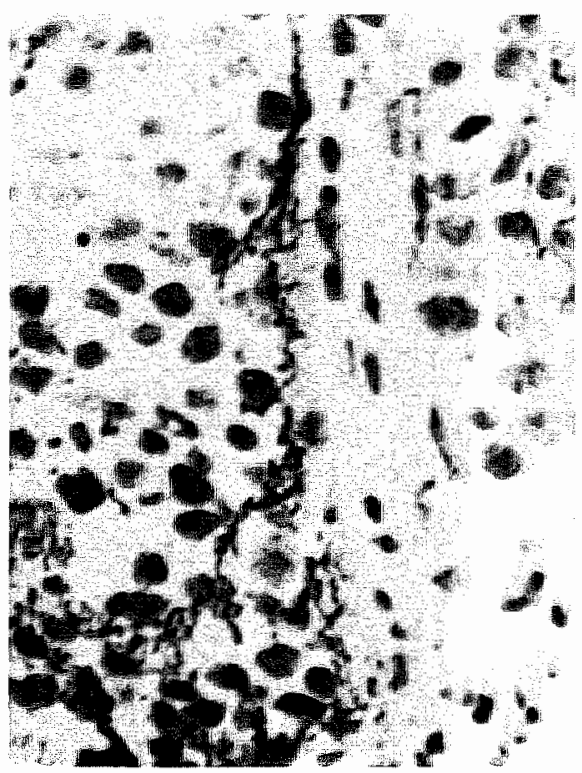

Fig. 7. Frozen sections of xenografts of WISH and KB cells in nude rats (immunoperoxidase $560 \mathrm{x}$ ).

A. Monoclonal human specific antibody (1042) to type IV collagen applied to WISH xenograft.

B. Monoclonal human specific antibody (1043) to type IV collagen applied to KB Xenograft.

BM deposition at the tumor stromal border as well as intercellular.

Our preliminary results with WISH and KB cells grown in collagen lattices, however, do not support this contention. In summary, the experiments described in this report indicate that in colonic carcinoma cells 5583-S BM in the extracellular matrix may be exclusively of stromal origin. Additional experiments are required to elucidate the mechanisms of BM deposition in epithelial neoplasms.

\subsection{REFERENCES}

1. Kefalides NA, Alper R, Clark CC. Biochemistry and metabolism of basement membranes. Int Rev Cytol 1979: 61: 167-228.

2. Foidart JM, Bere EW, Yaar M, Remard SI, Gullino M, Martin GR, Katz SI. Distribution and 
immuno-electron microscopic localization of laminin, a noncollagenous bssement membrane gylycoprotein. Lab Inwest 1980; 42:336432.

3. Timpl R, Rohde H, Robey PG, Rennard SI, Foidart JM, Martin GR. Laminin - a glycoprorein from basement membranes. J Biol Chem 1979; 254: 9933 .9937.

4. Hassel JR, Robey PG, Barrach HJ, Wilcek J, Rennard SI, Martin GR. Isolation of a heparansulphate containing proteoglycan from basement membrane. Proc Natl Acad Sci USA 1980; 77 : $4494-4498$.

5. Buttin $P$, Chavanel $G$, Foidart IM, Martin E. Antigens of basement membrane in the perifumoral stroma in human colonic adenocarcinomas: An immunofluorescence study. Int I Cancer 1982; 30: $13-20$.

6. Gould VE, Battifora H. Origin and significance of the basal lamina and some interstitial fibrillar components in epithelial neoplasms. Pathol Annul 1976;11:353-386.

7. Kallioninen M, Atutio-Harmainen $H$, Dammert K, Risteli J, Ristelli $\mathbb{L}$. Discontinuity of the basement membrane in fibrosing basocellular carcinomas and baso squamous carcinomas of the skim: An immunohistochemical study with human baminin and type IV collagen anti-bodies. I Invest Dermatol 1984; 82: 248-251.

8. Liota LA, Rao CN, Barsky SH. Tumor invasion and the extracellular matrix. Lab Invest 1983; 49: 636-649.

9. McArdle JP, Muller HK, Roff BT, Murphy WH. Basal lamina nedevelopment in tumours metastatic to brain: an immunoperoxidase study using an antibody to iype IV collagen. In J Cancer 1984; $34: 633-638$.

10. Terranova VP, Williams JE, Liotta LA, Martin R. Modulation of the meiastatic activity of melanoma cells by laminin and fibronectin. Science 1984; 226: 982-985.

11. Forster SJ, Talbot IC, Gritchley DR. Laminin and fibronectin in rectal adenocarcinomas: relationship to tumour grade, stage and metastasis, Br J Cancer 1984; 50: 51 61.

12. Damjanov I, Damjanov N, Knowless BB, Engvall E. Origin of laminin in the extracellular matrix of human tumor xenografts in nude mice. Virchows Arch (Cell Pathol) 1985; 49:45-52.

13. Verstijnen CPHJ, Arends JW, Moerkerk PTM, Geraedts JPM, Uitendaal MP, Bosman FT, The establishment and characterization of two new cell lines derived from a single human colonic adenocarcinoma. Virchows Arch (Cell Pathol) 1987; 53: 191-197.

14. Hayflick $\mathbb{L}$. The establishment of a line (WISH) of human amnion cells in continuous cultivation. Exp Cell Res 1961; 23: 14-20.

15. Eagle H. Propagation in a fluid medium of human epidermoid carcinoma strain KB. Proc Soc Exp Biol (N.Y.) 1955; 89: 362-364.

16. Nusgens B, Merrill C, Lapiere C, Bell E. Collagen biosynthesis by cells in a tissue equivalent matrix in vitro. Coll Rel Res 1984; 4: 351-364.

17. Havenith MG, Cleutjens JPM, Beek C, v.d. Linden JE, De Goeij AFPM, Bosman FT. Human specific anti-type IV collagen monoclonal antibodies, characterization and application to immunohistochemistry. Histochemistry 1987; 87: 123-128.

18. Verstijnen $C P H J$, ten Kate J, Arends JW, Schutte $\mathbb{B}$ and Bosman FT. Xenografting or normal colonic mucosa in athymic mice. J Pathol 1988; 154:

19. Laemmli UK. Cleavage of structural proteins during the assembly of the head of the bacter. ophage T4. Nature 1970; 227: 680-685.

20. Towbin H, Stachelin T, Gordon J. Electrophoretic transler of proteins from polyacrylamide gèls to nitrocellulose sheets: procedure and some applications. Proc Nall Acad Sci USA 1979; 76: $4350 \times 4354$.

21. Holmstrup P. Studies on the deposition of aminin and type IV collagen in human oral mucosat transplanted to mude mice. Acta Pathol Microbiol Immunol Scand Sect A 1985; 93: 1-8.

22. Demarchez M, Hartmann DJ, Prunieras M. An immunohistochemical study of the revascularizattion process in human skin transplanted onto nude mouse. Transplantation 1987; 43: 896-903.

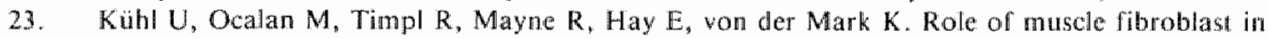
the deposition of type IV collagen in the basal lamina of myotubes. Differentiation 1984; 28 : 164-172. 



\section{CHAPTER 4}

\section{Type IV collagen immunoreactivity in colorectal cancer: Prognostic value of basement membrane deposition *}

\subsection{INTRODUCTION}

Invasion and metastasis are hallmarks of malignant neoplasia and frequently deter * mine the course of the disease. Invasion precedes metastasis and interactions between tumor cells and the extracellular matrix are involved in this dynamic process (1-3). In carcinomas the first step is penetration through the epithelial basement membrane (BM). BM degrading proteases such as type IV collagenase play an important role in this process $(4,5)$. BM, however, are not static structures, that can only be destructed, but may also be deposited in tumor tissue. Conceivably the presence of BM in a neoplasm might be an expression of the type of interaction of tumor cells with the extracellular matrix. Such information might be related to the biological behavior of the neoplasm.

In this context Stenbäck et al. studied BM in endometrial adenocarcinomas. Well differentiated tumors contained ex.ensive and continuous BM, whereas poorly differentiated adenocarcinomas were characterized by the absence of continuous BM (6). Very few reports have been published concerning BM in colorectal cancer. Burtin et al. showed by immunofluorescence, using antibodies to the BM components type IV collagen and laminin, an almost complete absence of BM at the periphery of colorectal adenocarcinomas (7). Lymph node metastases mostly showed less extensive BM deposition tlan the primary tumor (8). We have previously found that colonic adenomas with severe dysplasia show irregular defects in their epithelial BM (3). Forster studied the relationship between the deposition of BM and metastatic propensity in colorectal carcinomas by immunohistochemical staining for laminin 9). Limited deposition of BM in primary lumors correlated significantly with a higher incidence of distant metastases and reduced patient survival (10). We have performed a similar study, using immunohistochemistry to detect type IV collagen in BM in collorectal carcinomas. Patterns of BM deposition were correlated with macroscopical (Dukes" stage) and microscopical (degree of differentiation) information and with follow up data.

\subsection{MATERIAL AND METHODS}

For this study we used clinicopathological information and tissuespecimens of 350 cases of colorectal carcinoma, collectedprospectively in a multicenter study (11).

* Havenith MG. Arends JW, Simon REM, Volovics A, Wiggers T, Bosman FT Accepted for publication in Cancer 


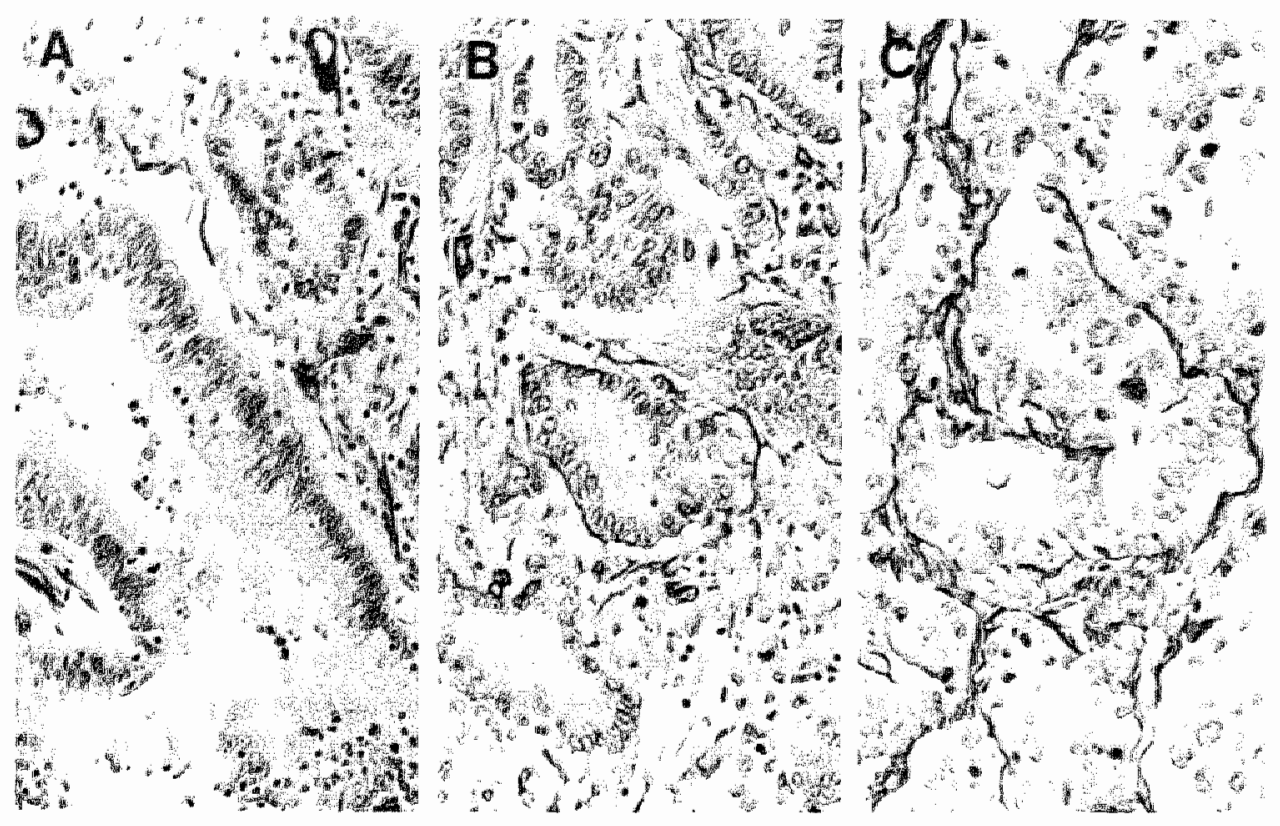

Fig 1. Variation in BM deposition.

A; Limited BM deposition. B; Moderate BM deposition. C; Extensive BM deposition.

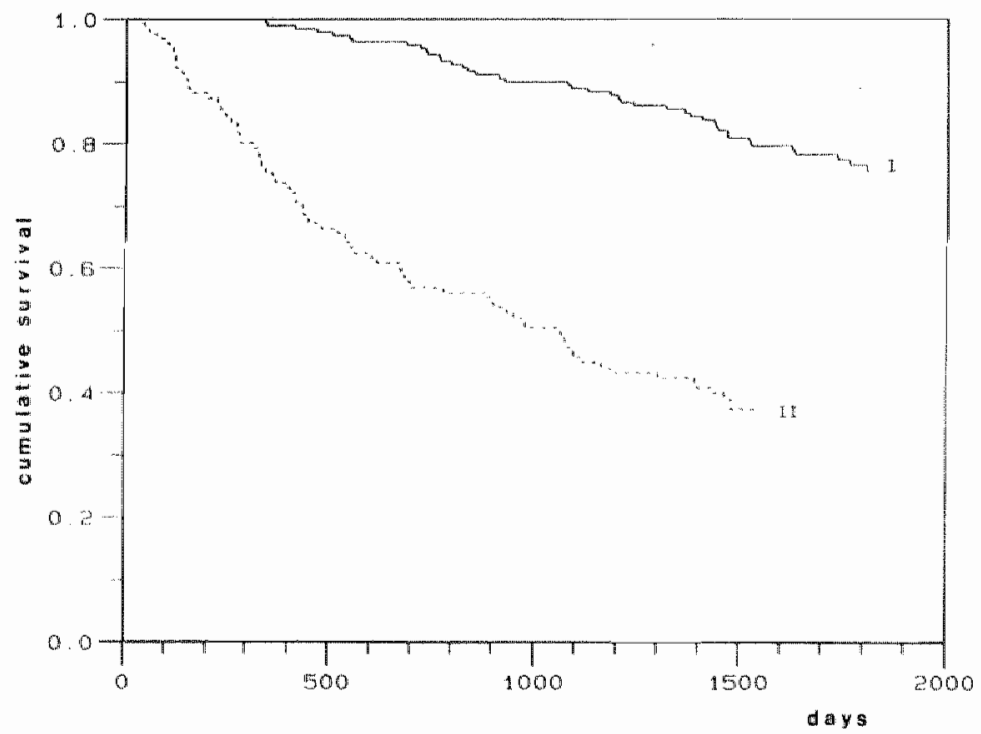

Fig 2. Survival data of Dukes" stages $A / B$ wersus stages C/D.

I; Dukes" stages A and B. II; Dukes" stages $C$ and D (log rank test $p<0.01$ ). 


\subsubsection{Case material}

Staging of the tumors was performed according to the Dukes' classification as modified by Turnbull (12). Stage A tumors were confined to the bowel wall; stage B tumors extended into the pericolic fat; stage $C$ tumors had regional lymph node metastasis and stage $\mathrm{D}$ tumors either invaded into adjacent organs or had distant metastases. All clinicopathological data were stored in a computerized database. Al regular intervals follow-up data, including survival information, were collected.

\subsubsection{Inmunohistochemistry}

For histological and immunohistochemical evaluation cross sections trough the center of the tumor, at the site of the deepest invasion, were selected. Routinely formalin fixed and paraffin embedded tissue blocks were sectioned at $4 \mu \mathrm{m}$. Paraffin sections were deparaffinized, rehydrated and pretreated with pepsin $(0.1 \%$ in 0.1 $\mathrm{M} \mathrm{HCl}$, for $30 \mathrm{~min}$ at room temperature) to restore immunoreactivity to type IV collagen (13). After blocking of endogenous peroxidase $(20 \mathrm{~min}$. in methanol with $\left.0.3 \% \mathrm{H}_{2} \mathrm{O}_{2}\right)$ and washing in PBS $(3 \times 5 \mathrm{~min}$.) the sections were incubated with anti type IV collagen antiserum (diluted 1:200 in PBS with 1\% BSA) for 1 hour at room temperature in a moist chamber. After washing in PBS the sections were incubated with peroxidase labeled goat anti rabbit Ig antibodies (Ih RT). After final washing with PBS, a diaminobenzidine- $\mathrm{H}_{2} \mathrm{O}_{2}$ substrate was used to visualize the immunoreactivity.

As primary antibody a cross-species reactive anti-type IV collagen antiserum raised in rabbits was used. Immunoreactivity and specificity of this antiserum has been described elsewhere (13). Briefly, under immunohistochemical conditions the antibodies reacted only with type IV collagen and not with types 1 , III and V collagen nor with laminin. All BM in normal tissues could be visualized by immunostaining with this antibody.

The amount of immunoreactivity at the tumor-stromal interface was scored semiquantitatively in the tumor center only, as in the tumor periphery invariably limited BM was found. When more than $75 \%$ of the linear tumor cell-stromall interface showed type IV collagen immunoreactivity this was scored as extensive BM deposition. When this amounted between $25 \%$ and $75 \%$ the score was moderate and less than $25 \%$ was classified as limited BM deposition. These patterns are illustrated in Fig 1.

In all cases the overall extent of BM deposition at the tumor cell-stroma interface of the whole section, covering a large tumor area at the site of deepest invasive growth, was scored. 


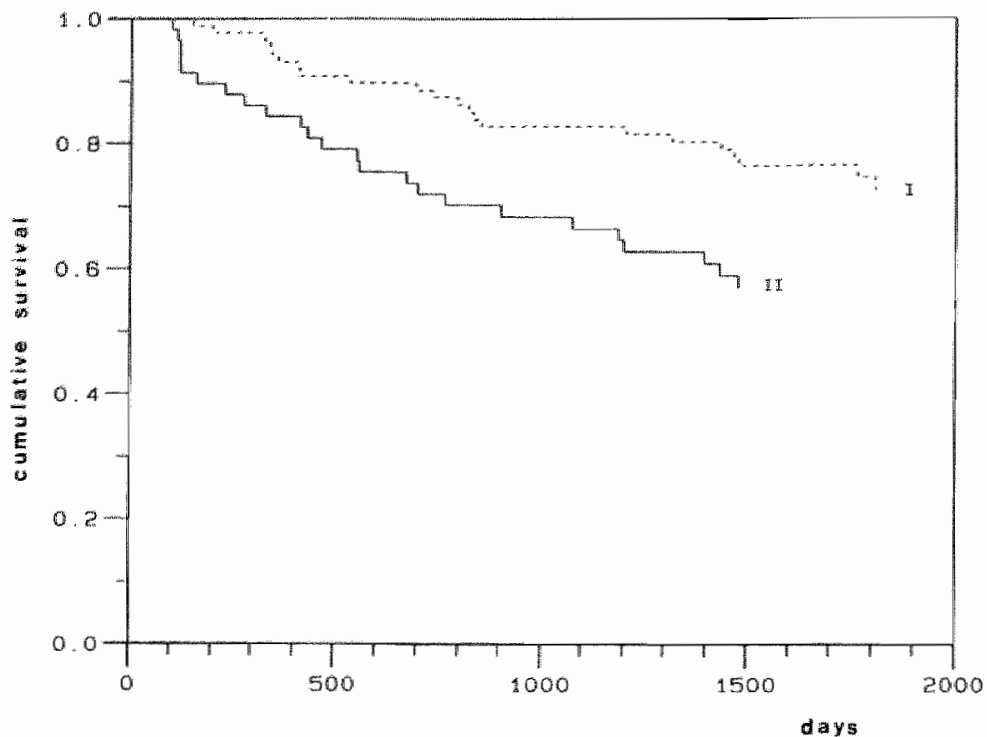

Fig 3. Survival data of extensive and moderate versus limited BM deposition.

1; Extensive and moderate BM deposition. II; Limited BM deposition (log rank test $\mathrm{p}<0.01)$.

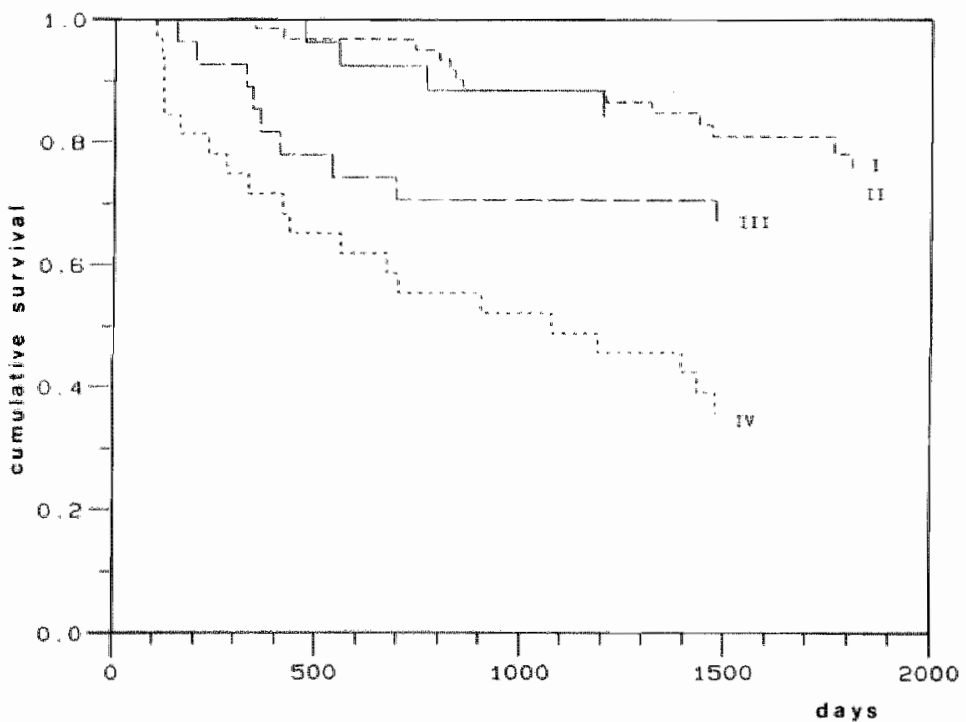

Fig 4. Survival data after stratification of Dukes" stages and BM deposition.

I; Dukes' stages $\mathrm{A}$ and $\mathrm{B}$ with extensive and moderate $\mathrm{BM}$ deposition. II; Dukes, stages $A$ and $B$ with limited BM deposition. II; Dukes' stages $C$ and $D$ with extensive and moderate BM deposition. Note the occurence of a plateau phase after two years. IV; Dukes' stages C and D with linited BM deposition (log rank test $\mathrm{p}<0.01$ ). 


\subsubsection{Statistical analysis}

Correlations between parameters in cross-tabulations were analyzed by the Chisquare test. Survival data were analyzed by a logrank test (14). Death due to postoperative complications, including all deaths within thirty days after operation, and non-disease related deaths were excluded for analysis of survival data.

\subsection{RESULTS}

\subsubsection{Immunohistochemistry}

Paraffin sections of all 350 colorectal carcinomas were stained. Subendothelial BM, and BM surrounding individual smooth muscle fat and Schwann cells, were regarded as internal control in the tumor sections. Only when these BM stained properly, the immunostaining was considered to be appropriate. In only 163 cases reliable immunohistochemistry could be performed, due to our inability to restore type IV immunoreactivity by pepsin pretreatment. Cases with unreliable immunohistochemistry were found to be randomly distributed over all Dukes stages.

\subsubsection{Clinicopathological data}

In the periphery of all colorectal carcinomas, invariably a limited $\mathrm{BM}$ deposition was found. However, the central parts of the tumors showed a markedly variable immunoreactivity at the tumor/stroma interface, varying from limited to extensive BM deposition (Fig 1). For statistical reasons extensive and moderate BM deposition were combined and compared with limited $\mathrm{BM}$ deposition in a cross-table with Dukes' stages A and B (no metastasis), and Dukes' stage C and D (metastasis). The results are shown in Table 1. In Dukes", stages A and B the cases with extensive and moderate BM deposition appeared to be overrepresented and those with limited BM deposition were underrepresented. In Dukes" stages $C$ and $D$ the opposite pattern occurred $(p<0.01)$.

Overall survival data of all 350 patients classified into Dukes' stages $A$ and $B$ and Dukes' stages $C$ and $D$ cases were analyzed. Actuarial survival curves are shown in Fig 2. Patients with Dukes' stage C or D carcinomas appeared to survive significantly shorter $(\mathrm{p}<0.01)$ than those with Dukes'stages A and B carcinomas. Survival data of cases with extensive and moderate $\mathrm{BM}$ deposition were compared to those with limited BM deposition (Fig 3). Patients with limited BM deposition in colorectal carcinomas showed a significantly shorter survival $(p<0.01)$, compared to those with moderate and extensive BM deposition. Stratification of the cases for limited versus moderate/extensive BM deposition and Dukes" stages $A / B$ and $C / D$ resulted in the survival curves shown in Fig 4. In Dukes' stages A and B, BM deposition did not correlate with survival. However, in Dukes' stages $C$ and $D$ survival was signifi- 
Table 1. Crosstable: Dukes stages versus BM deposition.

\begin{tabular}{|c|c|c|c|c|c|}
\hline & & & \multicolumn{2}{|c|}{ BM deposition } & \\
\hline & & & $E / M$ & LIM & \\
\hline \multirow{4}{*}{$\begin{array}{l}\text { Dukes' silages } \\
\mathrm{A} / \mathrm{B}\end{array}$} & \multicolumn{2}{|l|}{ number } & 67 & 30 & 97 number \\
\hline & row & $\%$ & 69.1 & 30.9 & $59.5 \%$ \\
\hline & column & $0 \%$ & 67.7 & 46.9 & \\
\hline & total & $\% 7$ & 47.1 & 18.4 & \\
\hline \multirow{4}{*}{$\begin{array}{l}\text { Dukes' stages } \\
\text { C/D }\end{array}$} & \multicolumn{2}{|l|}{ number } & 32 & 34 & 66 number \\
\hline & row & $\%$ & 48.5 & 51.5 & $40.5 \%$ \\
\hline & collumn & $\%$ & 32.3 & 53.1 & \\
\hline & total & $\% / 0$ & 19.6 & 20.9 & \\
\hline \multirow[t]{2}{*}{ Column total } & \multirow[t]{2}{*}{ number } & & 99 & 64 & 163 number \\
\hline & & $\%$ & 60.7 & 39.3 & $100 \%$ \\
\hline
\end{tabular}

cantly shorter $(p<0.01)$ in cases with limited BM deposition. In this group cases with Dukes' stages C and D were equally represented (7 Dukes' $C$ versus 8 Dukes' D), which excludes the possibility of overrepresentation of Dukes' D cases. Survival in the group with moderate and extensive BM deposition reached a plateau phase after two years (fig 4).

\subsection{DISCUSSION}

In carcinomas, a dynamic interaction occurs at the interface between tumor cells and the surrouncling mesenchymal stroma. Collagenases, including specific type IV collagenase, and other proteases such as plasminogen activators, cathepsins, and heparanases form a cascade system of enzymes facilitating extracellular matrix breakdown $(4,15,16)$. Conversely, as a host reaction to the invading neoplasm extracellular matrix components, including $\mathrm{BM}$ material and interstitial collagens may, also be deposited around the tumor cells $(17,18)$. Stromal desmoplastic reaction around tumor cells, in which myofibroblasts are involved, might play a role in BM deposition at the tumor-stromal interface. It is tempting to speculate, on the basis of the previously reported information and our own studies, that extensive BM deposition in a neoplasm is a sign of competent host response or of limited invasive potential and might indicate low metastatic capability.

Against this background we studied BM deposition by immunohistochemical demonstration of type IV collagen in colorectal carcinomas. Consistent with the hypothesis formulated above, in the invasive periphery of the tumor BM deposition was scarce or completely absent. In the tumor center, however, a highly variable pattern of BM deposition occurred. Why some tumors do and others do not show 
BM deposition is currently unknown. It is likely that limited BM deposition is caused by highly active protease secretion by tumor cells together with low type IV collagen synthesis or inability of the tumor cells to deposit type IV collagen into an organized BM.

The most interesting finding was the correlation of BM deposition pattern with prognosis. In Dukes' stages $A$ and $B$ cases moderate and extensive BM deposition occurred more frequently, but within these prognostically favorable stages, the amount of BM deposition had no influence on patient survival. In contrast, in Dukes' stages C and D, limited BM deposition occurred more frequently. Cases with limited BM deposition showed a highly significant shorter survival $(p<0.01)$. Cases with extensive and moderate BM deposition showed a plateau phase in the survival curve after two years of follow up. Death during the first two years could be ex* plained by cases in Dukes' stage $D$ and by micrometastases in the liver, already present at the time of surgical resection of Dukes' stage C cases. Cases with limited BM deposition showed a continuously downward course of the survival curve, which could be explaned by locoregional recurrences causing liver metastasis after a longer postoperative interval. These findings suggest that immunostaining of BM in Dukes' stage C differentiates tumors with relatively low invasive and metastatic capacity from tumors with a high invasive and metastatic capacity.

Poorly differentiated tumors showed a trend towards limited BM deposition and well differentiated tumors towards moderate/extensive BM deposition. These findings are in agreement with other studies $(6,7,9,10)$. Because of the limited number of well or poorly differentiated carcinomas stratification according to tumor grade could not be performed.

Absence of the adhesive glycoprotein laminin, which occurs only in the BM, has been postulated as an explanation for the higher incidence of metastases and subsequent lower patient survival in colorectal carcinomas (10). However, our finding that type IV collagen deposition shows a similar correlation with survival, suggests that $\mathrm{BM}$ in carcinomas may also have a barrier function. In conclusion, we have shown that the pattern of $\mathrm{BM}$ deposition in the center of colorectal carcinomas is highly variable. Deposition of appreciable amounts of $\mathrm{BM}$ material appears to be a prognostically favorable sign. How patterns of BM deposition can influence clinical behavior is an interesting subject for further studies.

\subsection{REFERENCHS}

1. Liota LA, Rao CN, Barsky SH. Tumor invasion and the extra cellular matrix, Lab lavesi 1983; 49: 636-6.49. 
2. Albrechtsen R, Wewer UM, Liotta LA. Basement membranes in human cancer. Pathol Anmul $1986 ; 21: 251-276$.

3. Bosman FT, Havenith MG, Cleutjens JPM. Basement membranes in cancer. Uttrastruct Pathol $1985: 8: 291-304$.

4. Barky SH, Togo S, Garbisa S, Liona LA. Type IV collagenase immunoreactivity in invasive breast carcinoma. Lance 1983; 1: 296.

5. Liotta LA, Tryggvason K, Garbisa S, Hart I, Foltz CM, Shafie S. Metastatic potental correlates with enzymatic degradation of basement membrane collagen. Nature 1980; 284: 67-68.

6. Stenbäck F, Risteli $J$, Risteli $L$, Wasenis V-M. Basement membrane laminin and type IV collagen in endometrial adenocarcinoma: Relation to differentiation and treatment. Oncology 1985; 42: $370-376$.

7. Burtin $P$, Chavanet $G$. Foidart JM, Martin E. Antigens of the basement membrane and the perilumoral stroma in humar colonic adenocarcinomas: An immunofluorescence study. Int $\mathrm{J}$ Cancer 1982; 30: 13-20.

8. Burtin $\mathbb{P}$, Chavanel $G$, Foidart JM, André $J$. Alterations of the basement membrane and conneclive tissue antigens in human metastatic lymph nodes. Int $J$ Cancer 1983; 31: 719-726.

9. Forster $S J_{\text {, Talbot }} \mathbb{C}$, Critchley $D R$. Laminin and fibronectin in rectal adenocarcinoma: Rela* fionship to tumour grade, stage and metastasis. Br J Cancer 1984; 50:51-60.

10. Forster SJ, Talbot IC, Clayton DG, Critchley DR. Tumor basement membrane laminin in adenocarcinoma of rectum: An immunohistochemical study of biological and clinical signiffeance. Int J Cancer 1986; 37: 813-817.

11. Wiggers $\mathrm{T}$, Jeckel J, Arends JW et al. The no touch isolation technic in colorectal cancer: a prospective controlled multicentre trial. Br J of Surg 1985; 72: suppl: S 13.

12. Turnbull RB Jr, Kyle M, Watson FR, Spratt J. Cancer of the colon: the influence of isolation techniques on survival rates Ann Surg 1967; 166: 420-427.

13. Havenith MG, Cleutjens. JPM, Beek C, v.d. Linden E, de Goeij AFPM, Bosman FT. Human specific anti type IV collagen antibodies, characterization and immunohistochemical application. Histochem 1987; 87: 123-128.

14. Mantel N. Evaltation of surviwal data and two new rank order statistics arising in its consideration. Cancer Chemther Rep 1966; 50: 163-170.

15. Thorgeirsson UP, Turpeenniemi-Hujanen T, Liotta LA. Cancer cells, components of basement membranes, and proteolytic enzymes. Int Rev Exp Pathol 1985; 27: 203-234.

16. Liond LA, Rao N, Wewer UM. Biochemical interactions of tumor cells with the basement membrane. Ann Rev Biochem 1986; 55: 1037-1057.

17. Barsky SH, Gopalakrishna R. Increased invasion and spontaneous metastasis of BL6 melanoma with inhibition of the desmoplastic response in C57 BL/6 mice. Cancer Res 1987; 47: 1663-1667.

18. Lagacé R, Grimaud JA, Schürch W, Seemayer TA. Myofibroblastic stromal reaction in carcinoma of the breast: variations of collagenous matrix and structural glycoproteins Virchows Arch (Pathol Anat) 1985; 408: 49-59. 


\section{CHAPTER 5}

\section{Basement membranes in bronchogenic squamous cell carcinoma: An immunohistochemical and ultrastructural study *}

\subsection{INTRODUCTION}

Invasive growth of cancer cells is a complicated process in which specific interactions between tumor cells and the extracellular matrix are involved (1). In tumor pathology, penetration of the basement membrane (BM) by carcinoma cells, followed by migration into the interstitial stroma, is often regarded as the first sign of invasive growth (2-4). Consequently, at the point of invasion the BM is usually discontinuous $(5,6)$. In solid organs tumor cells invade into the surrounding mesen chymal stroma. In the lung, however, specific anatomic characteristics might influence the pattern of invasion of neoplastic cells. Axial connective tissue surrounds the bronchi and large vessels, whereas peripheral connective tissue underlies the pleural mesothelium and extends into fissures. The delicate connective tissue in the alveolar walls forms the bridge between the axial and peripheral connective tissue (7). In the initial stage of bronchogenic squamous cell carcinomas, invasive growth in the lung is comparable to invasion in solid organs. However, when carcinoma cells gain entrance into the intra-alveolar compartment, the functional barrier formed by the interstitial stroma, alveolar BM, and epithelium is lost and tumor cells actually grow in the extracorporal space. This could lead to striking differences of invasive growth patterns between carcinomas in solid organs and primary as well as metastatic Iung tumors. Recently, these differences have been described at the ultrastructural level in bronchogenic squamous cell carcinomas $(8,9)$.

Hitherto, at the light microscopic level, no reports on the role of $B M$ in invasive growth in the lung are known. Visualization of the BM at the light microscopic level thas been attempted with conventional histochemical methods such as periodic acid Schiff staining (PAS) and silver impregnation techniques like Gomori's reticulin staining. These staining methods are not specific for $\mathrm{BM}$, because structural proteins in the interstitial stroma are also stained $(10,11)$. Since antibodies to $B M$ constituents have become available, immunolocallization of $\mathrm{BM}$ at the light, as well as the electron microscopic level is possible (12-15).

In the present report we studied BM patterns in squamous cell carcinomas of the lung by immunohistochemistry, using antibodies to type IV collagen and laminin, and by electron microscopy. The following questions were addressed: 1.are the results of immunohistochemistry of BM components in bronchogenic squamous cell

\footnotetext{
* Havenith MG, Dingemans KP, Cleujens JPM, Wagenaar SiSc, Bosman FT. Subnitted to Ultrastructuratl Pathology.
} 
Fig I Western blot of mouse laminin, reacted with polyclonal rabbit anti mouse laminin antibodies.

carcinomas and electron microscopy comparable; 2 .does invasive growth into alveolar septa in the periphery of squamous cell carcinomas of the lung occur, and if so, is it detectable at the light microscopic level; 3 . which cells are present in the stromal compartment in the tumor center and what is the relationship of the tumor cells to the stromal compartment regarding BM deposition; 4.does inappropriate intercellular BM deposition occur, and is intracellular immunoreactivity to BM components detectable, in squamous cell carcinoma of the lung.

\subsection{MATERIALS AND METHODS}

\subsubsection{Tissues}

Tissue specimens of 27 squamous cell carcinomas of the lung were collected from lobectomy and pneumonectomy specimens, which were freshly obtained from the operating theatre. Unselected cases were used, the only criterion for inclusion in the study being the presence of cell bridges and/or keratinization, which are the light microscopic criteria for squamous cell carcinomas as given by the WHO (1981). Of each tumor, tissue was frozen in isopentane quenched in liquid N2 and stored at $-70^{\circ} \mathrm{C}$. Specimens from the peripheral and central parts were fixed in Karnovsky's fixative for electron microscopy, the remaining tissue was fixed in $4 \%$ neutral 

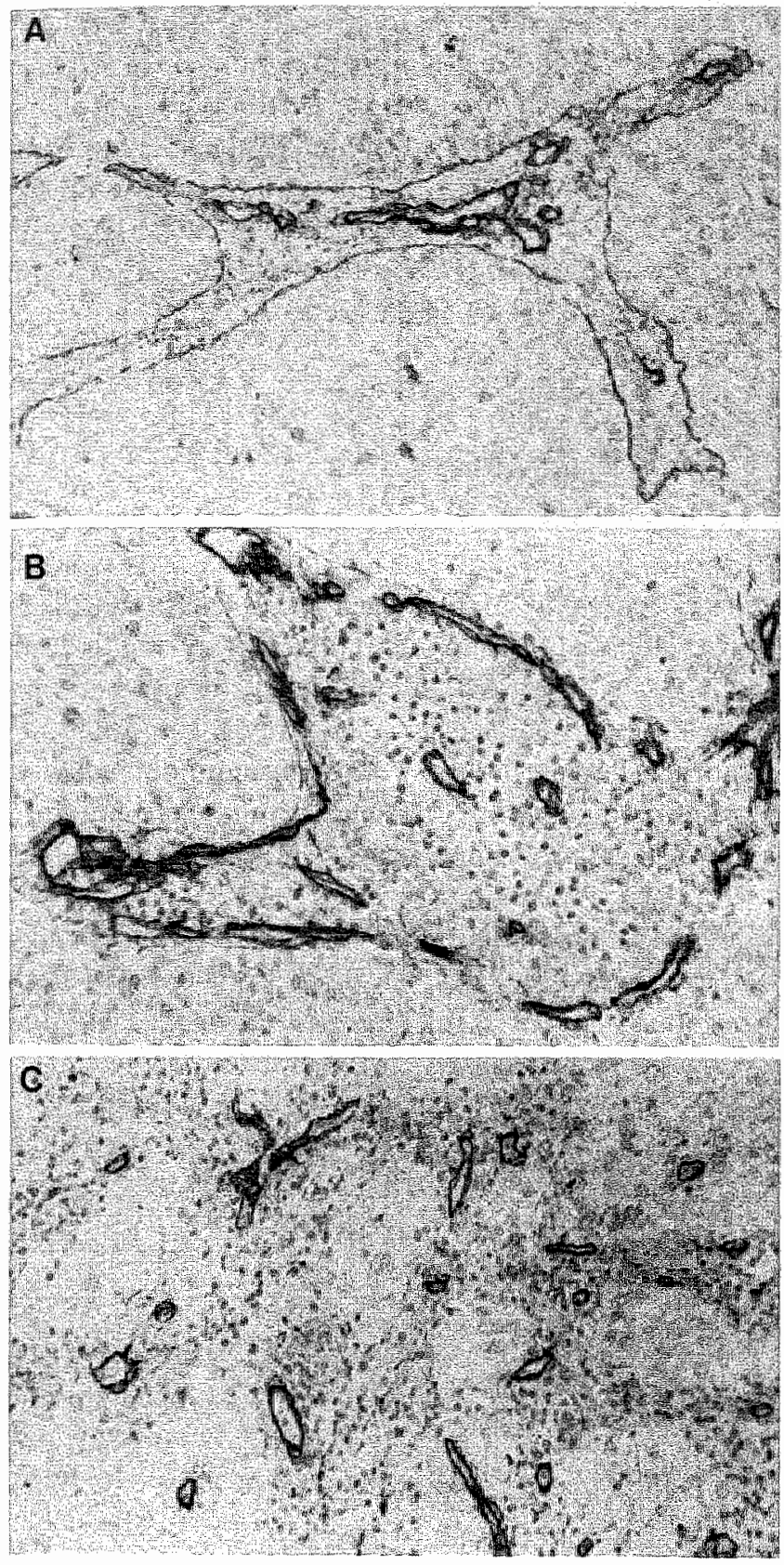

Fig 2 Frozen sections of bronchogenic squamous cell carcinoma reacted with polyclonal antibodies to type IV collagen (immunoperoxidase $240 \mathrm{x}$ ).

A. Extensive BM deposition.

B. Moderate BM deposition.

C. Limited BM deposition. 
buffered formaldehyde. After fixation in Karnowsky's fixative, for at least one hour the specimens were divided into $3 \times 3 \times 3 \mathrm{~mm}$ blocks (i.e. larger than usual for electron microscopy), postfixed with $\mathrm{O}_{5} \mathrm{O}_{4}$, rapidly dehydrated using 2,2-dimethoxypropane (16), and embedded in LX 112 resin. For immuno-electron microscopic demonstration of type IV collagen, samples from some of the tumors were fixed in $20 \%$ paraformaldehyde and embedded in Lowicryl $\mathrm{K} 4 \mathrm{M}$ at $-35^{\circ} \mathrm{C}$. The remaining tissue was sectioned for histopathological examination, after routine fixation in formalin and embedding in paraffin. One paraffin block of each case, containing peripheral as well as central parts of the tumor, was selected.

\subsubsection{Antibodies}

Polyclonal antibodies to human type IV collagen raised in rabbits, were applied to frozen and paraffin sections. Type IV collagen, used for immunization, was isolated from human placenta. Immunoreactivity and immunospecificity was tested by ELISA and immunoblotting. The polyclonal antiserum showed in ELISA a very weak immunoreactivity to type $\mathrm{V}$ collagen. However, by immunohistochemistry no immunoreactivity to interstitial stroma could be detected. The polyclonal antibodies stained all BM in a variety of normal human tissues. To obtain immunoreactivity, paraffin sections required enzyme preincubation. The best results were obtained with pepsin digestion. The details of these procedures have been described elsewhere (17).

Antibodies to Jaminin were raised in rabbits, immunized with commercially available mouse laminin (E/ $\mathrm{Y}$ Laboratories) isolated from EHS (Englebreth-HolmSwarm) mouse tumor (18). In antigen spot tests these antibodies lacked any immunoreactivity to type $\mathrm{I}, \mathrm{II}, \mathrm{IV}$ and $\mathrm{V}$ collagen. Western blotting studies revealed immunoreactivity at $200 \mathrm{Kd}$ as shown in Fig 1. To obtain immunoreactiwity, paraffin sections required enzyme preincubation as for antibodies to type IV collagen.

\subsubsection{Immunohistochemistry}

Frozen sections were fixed $20 \mathrm{~min}$ in acetone $\left(-20^{\circ} \mathrm{C}\right)$ and endogenous peroxidase was blocked in $0.3 \% \mathrm{H}_{2} \mathrm{O}_{2}$ in methanol, $20 \mathrm{~min}$, RT. After washing with PBS (3x5min) antibodies to BM components (diluted in PBS $1 \%$ BSA) were incubated for 1 hin a moist chamber. After washing with PBS the sections were incubated with peroxidase labeled rabbit anti mouse antibodies, for 1 h at $\mathrm{RT}$. After final washing with PBS, a diaminobenzidine- $\mathrm{H}_{2} \mathrm{O}_{2}$ substrate was used to visualize the immunoreactivity.

After deparaffinization, rehydration and enzyme preincubation, paraffin sections were treated like frozen sections, excepting fixation in cold acetone.

For immuno-electron microscopy thin sections of Lowicryl embedded tissues were 


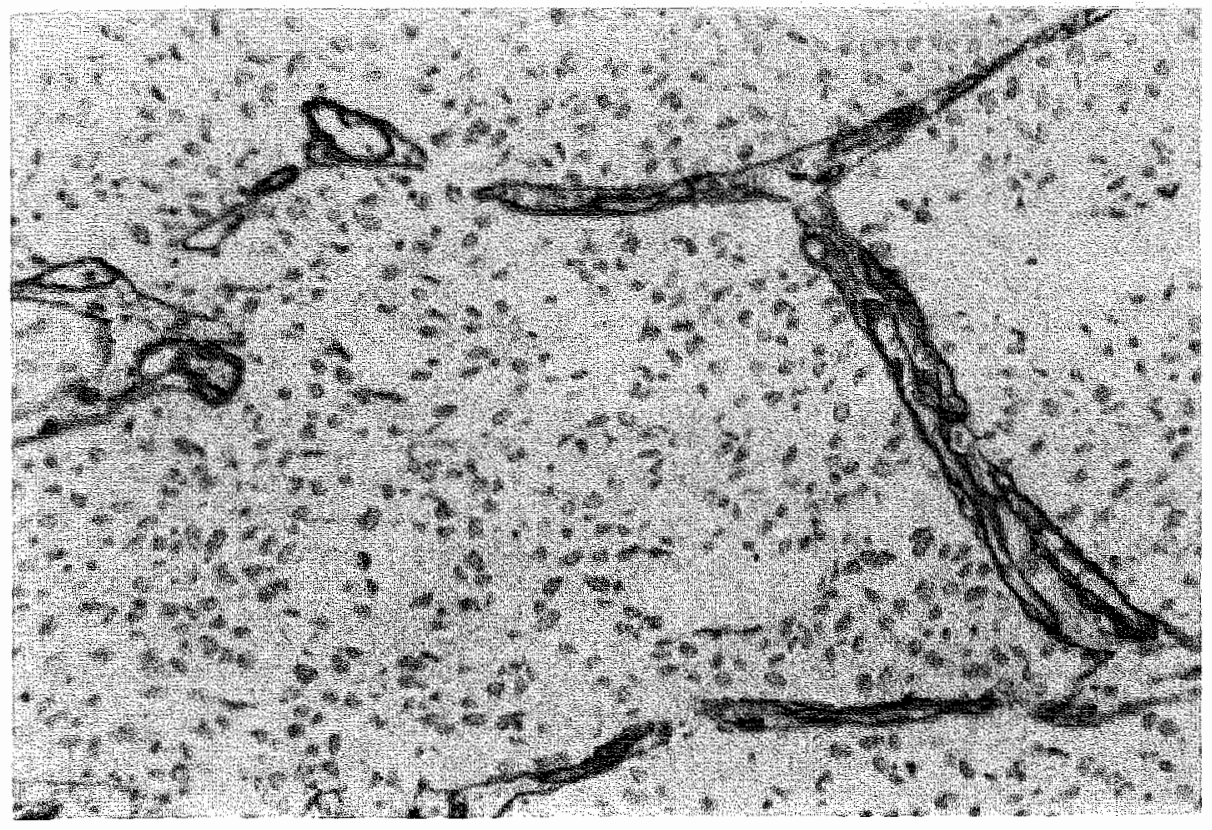

Fig 3 Frozen section of bronchogenic squamous cell carcinoma reacted with polyclonal an: tibodies to type IV collagen (immunoperoxidase 240x). Alveolar pattern in the periphery of the tumor.

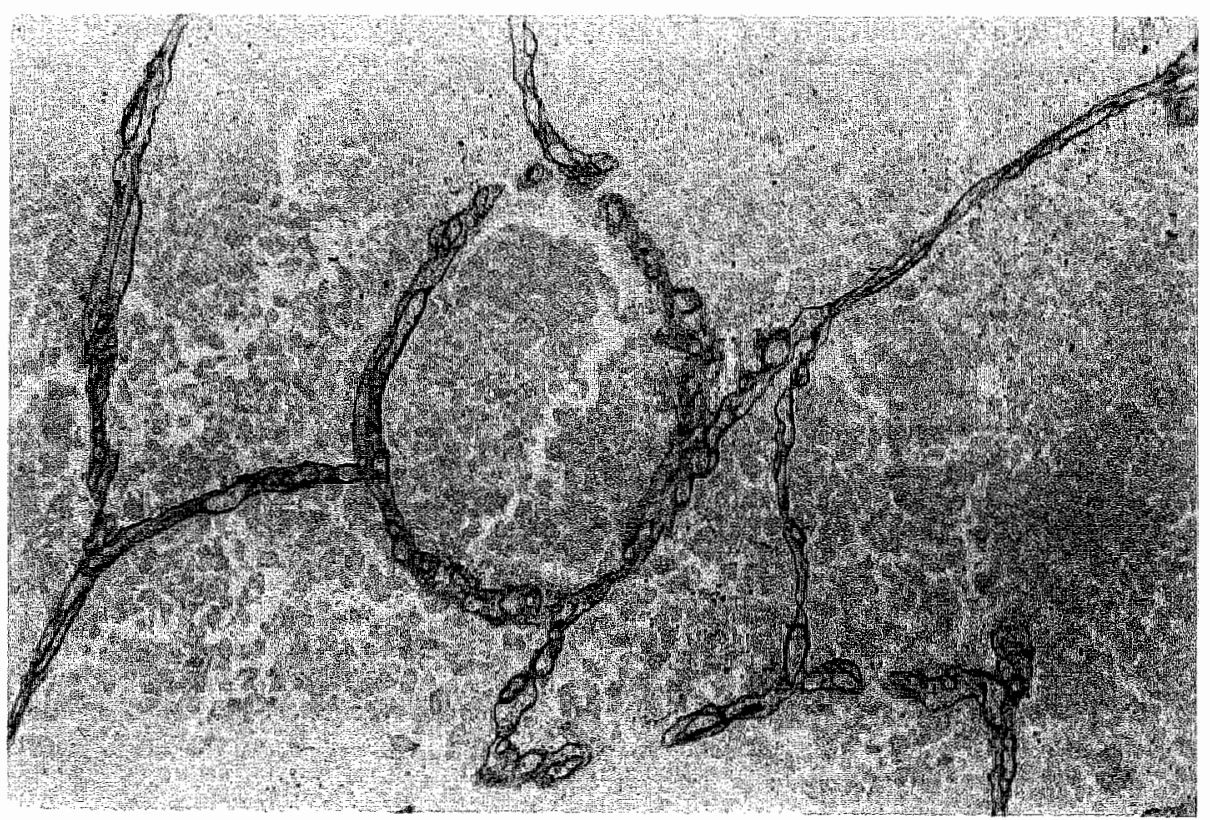

Fig 4 Paraffin section of bronchogenic squamous cell carcinoma reacted with polyclonal antibodies to type IV collagen (immunoperoxidase $60 \mathrm{x}$ ). 

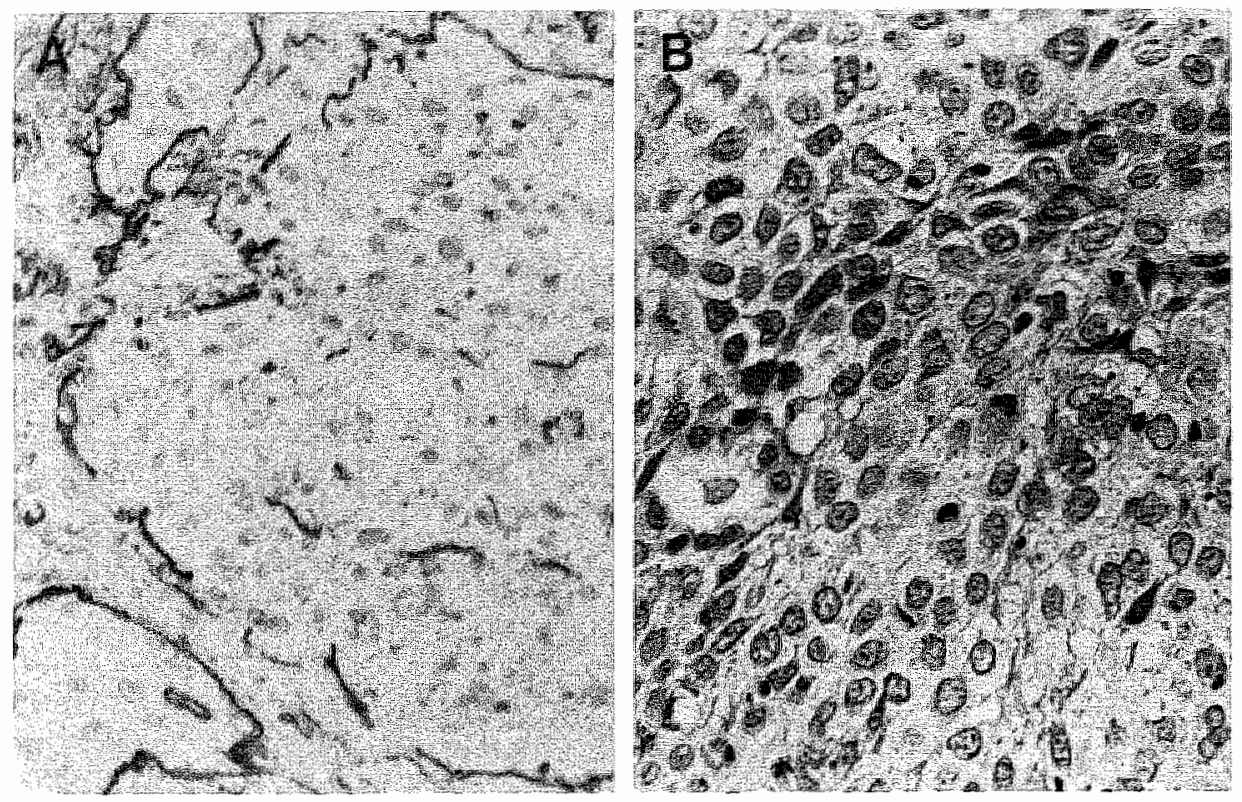

Fig 5 Frozen section (A) and paraffin section (B) of bronchogenic squamous carcinoma reacted with polyclonal antibodies to type IV collagen (immunoperoxidase, A 240x, B $375 \mathrm{x}$ ). A, intercellular BM deposition. B, granular immunoreactivity.

incubated with polyclonal anti type IV collagen antibodies and subsequently with goat anti rabbit $\mathrm{IgG}$, labelled with $15 \mathrm{~mm}$ gold particles (Janssen).

BM staining at the tumor-stroma interface was scored semiquantitatively. More than $75 \%$ immunoreactivity at the tumor-stromal border was scored as extensive BM, between 25 and $75 \%$ as moderate, and lower than $25 \%$ as limited BM expression (Fig 2).

\subsection{RESULTS}

In normal lung tissue all BM were stained with antibodies to type IV collagen and laminin in an identical pattern. Antibodies to type IV collagen gave a slightly higher staining intensity than antibodies to laminin.

In all tumors studied, the peripheral tumor tissue expanded into the alveolar spaces, while in close contact with the BM of the preexisting septa (Fig 3). Despite this close contact, the BM lacked discontinuities, and the tumor cell groups were surrounded by a continuous BM. Whereas invasion of the septa was never detected, tumor cells located in alveolar pores were occasionally observed, the adjacent alveolar walls showing uninterrupted BM (Fig 3). Even in necrotic areas, the alveolar pattern was clearly recognizable (Fig 4). In a few of the squamous cell carcinomas originating in large, centrally located bronchi, invasive growth was restricted to the peribronchi- 


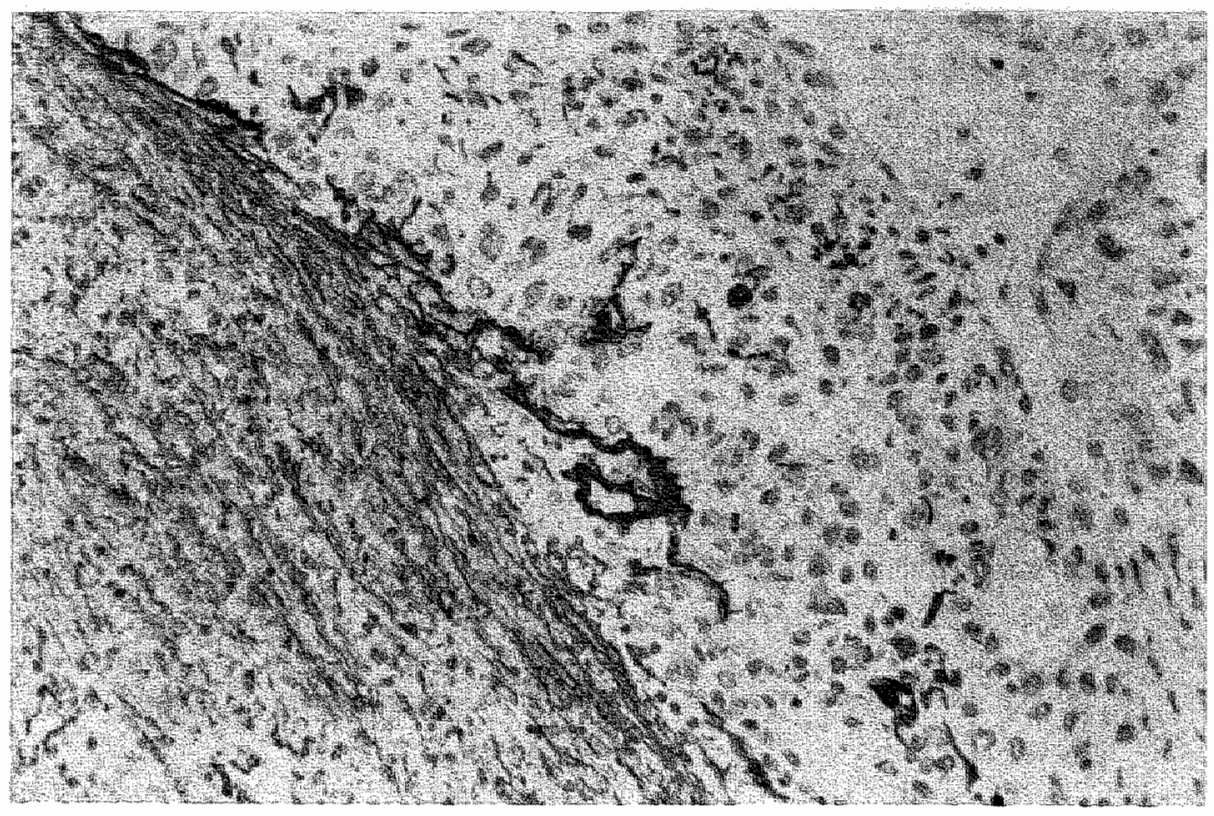

Fig 6 Frozen sections of bronchogenic squamous cell carcinoma reacted with polyclonal antibodies to type IV collagen (immunoperoxidase 240x). Irregular pericellular immunoreactivity in the stroma adjacent to the tumor.

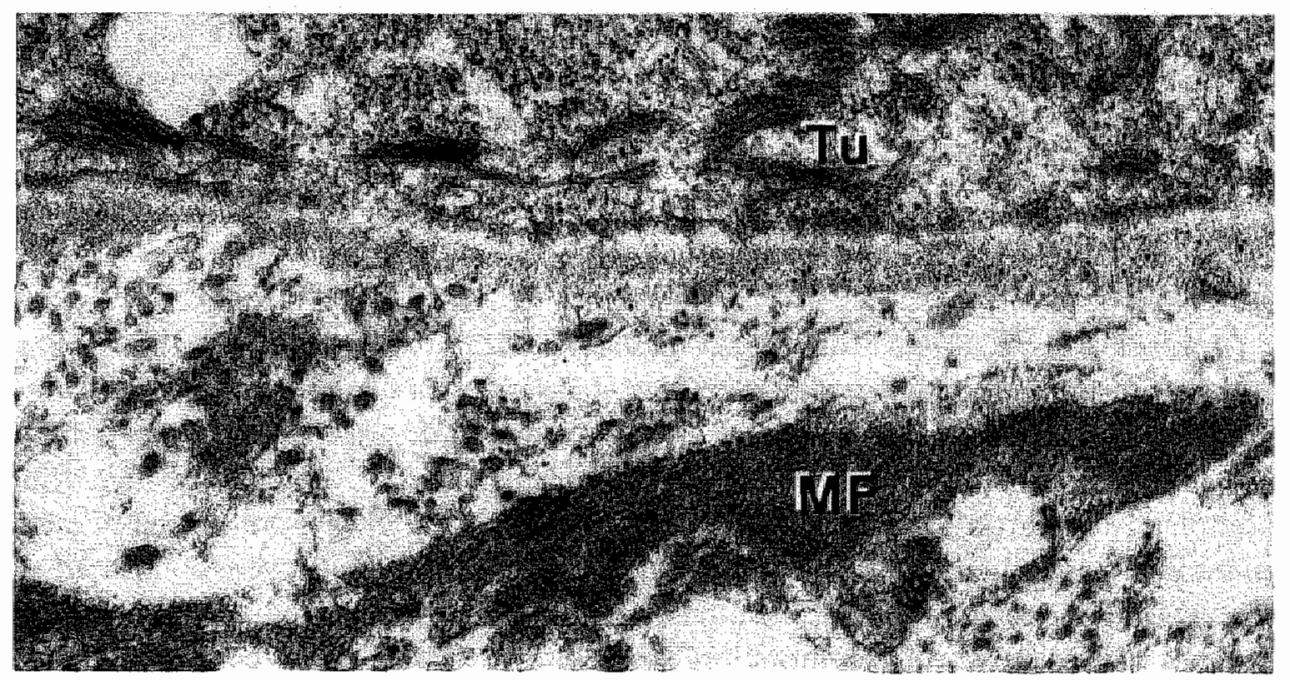

Fig 7. Immuno-electron microscopic demonstration of type IV collagen. Label is seen over lamina densa of BM separating tumor cells (Tu), characterized by tonofibrils, from stroma. Some granules are also found near surface of myofibroblasts (MF), characterized by microfilaments (36000x). 
al stroma. Consequently, these cases lacked a peripheral alveolar pattern.

In contrast to the tumor periphery, the more centrally located tumor regions consisted of irregular groups and strands of tumor cells separated by abundant stroma. In these regions, there was a highly variable $\mathrm{BM}$ deposition at the tumor stroma interface, ranging from continuous in about $50 \%$ of the tumors to almost completely absent in others (Fig 2). Small tumor cell clusters apparently invading the stroma showed the same variability as the larger tumor cell groups. There was no correlation between the grade of differentiation and the extent of BM deposition around the deeper tumor cell groups (e.g. some poorly differentiated tumors expressed almost continuous BM).

In the peripheral as well as the central regions of many tumors, some BM immunoreactivity was also found within the tumor cell groups. Occasionally, this reactivity was apparently due to the presence of $\mathrm{BM}$ associated with preexistent alveolar structures that were trapped by the tumor cells. In other instances, the immunoreactivity seemed to be located inside the tumor cells (Fig 5). In many instances, however, the exact position of this BM immunoreactivity could not be determined light microscopically.

The stroma present in the deeper tumor areas consisted of loose connective tissue containing blood vessels, spindle cells and inflammatory infiltrate. The vessels had a distinct, continuous BM, whereas the spindle cells showed irregular pericellular immunoreactivity (Fig 6).

The ultrastructural observations were largely in agreement with the light microscopic results. Immuno-electron microscopy using antibodies to type IV collagen confirmed that the lamina densa observed electron microscopically corresponded to the immunoreactive structures identified by light microscopy (Fig 7).

Only in a few tumors there was a slight disagreement between the extent of BM presence as determined by the two techniques; these differences were almost certainly due to the sampling errors which present a potential danger to any ultrastructural investigation, even when relatively large tissue blocks are used as in the present study.

There was a slight but consistent morphologic difference between the BM in the tumor periphery and that in the tumor center: whereas the BM in the periphery, which obviously represented the preexisting alveolar BM, generally lacked a lamina lucida (8), the BM surrounding the deeper tumor cell groups, which may have been completely or partially deposited by the tumor cells, were always composed of a lamina lucida and a lamina densa. In all instances, the tumor cells were connected to the BM by means of hemidesmosomes. It should be emphasized that even small patches of BM detected in tumors largely lacking a BM showed frequent hemidesmosomes (Fig 8).

The BM immunopositivity within tumor cell groups detected by light microscopy was found to correspond to one of the three following situations: a. seemingly intracellular BM was found to be located in deep invaginations of the tumor cells; not 


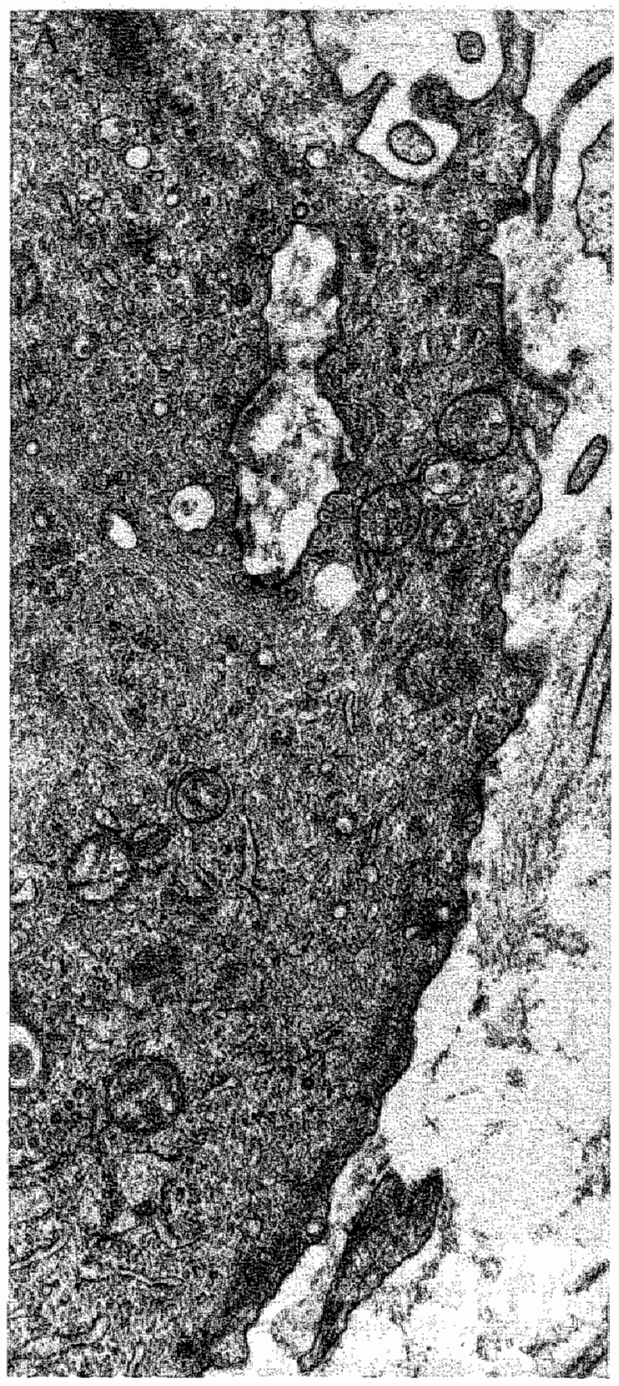

Fig 8. A . Part of tumor cell with irregular surface that is almost completely devoid of $\mathrm{BM}$.

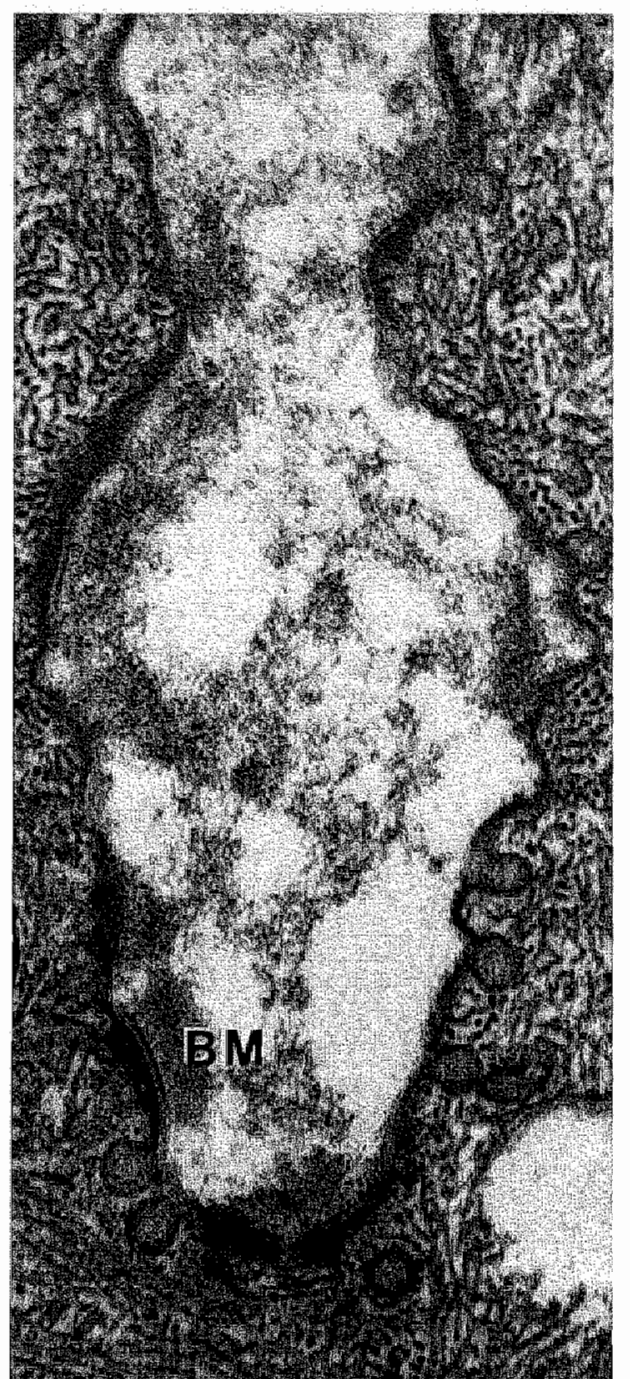

Fig. 8B. Enlargement of deep surface invagi nation in A. Notice hemidesmo. somes (characterized by fine, extracellular, electron-dense line) as. sociated with small patches of $B \mathrm{M}$. (A 18500x, B 73000x). 


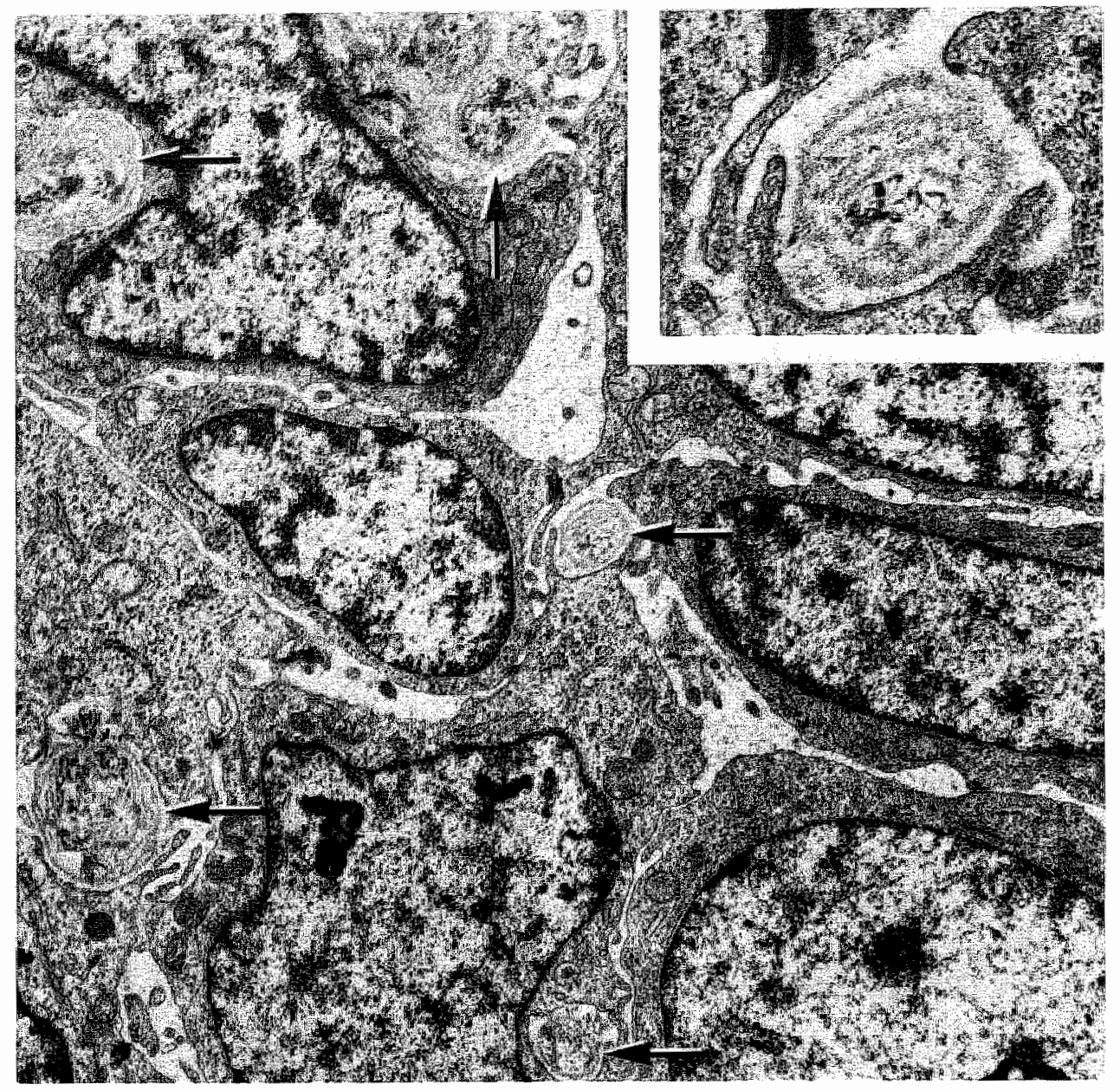

Fig 9. Tumor area with several rounded BM deposits (arrows) between tumor cells. Inset shows enlargement of deposit consisting of severall layers of BM around collagen fibers. $(7100 \mathrm{x}$, inset $32000 \mathrm{x})$.

infrequently, such small BM deposits were fully surrounded by tumor cell cytoplasm in the plane of the section (Fig 8); b. rounded deposits of BM with associated collagen fibers were found scattered over the tumor cell groups ( Fig 9); c.. remnants of BM were often attached to individual pneumocytes trapped by the tumor or the aggregates of a few trapped pneumocytes that were too small to be easily recognized by light microscopy (Fig 10).

In one tumor in which the deeper tumor cell groups were virtually devoid of BM, 

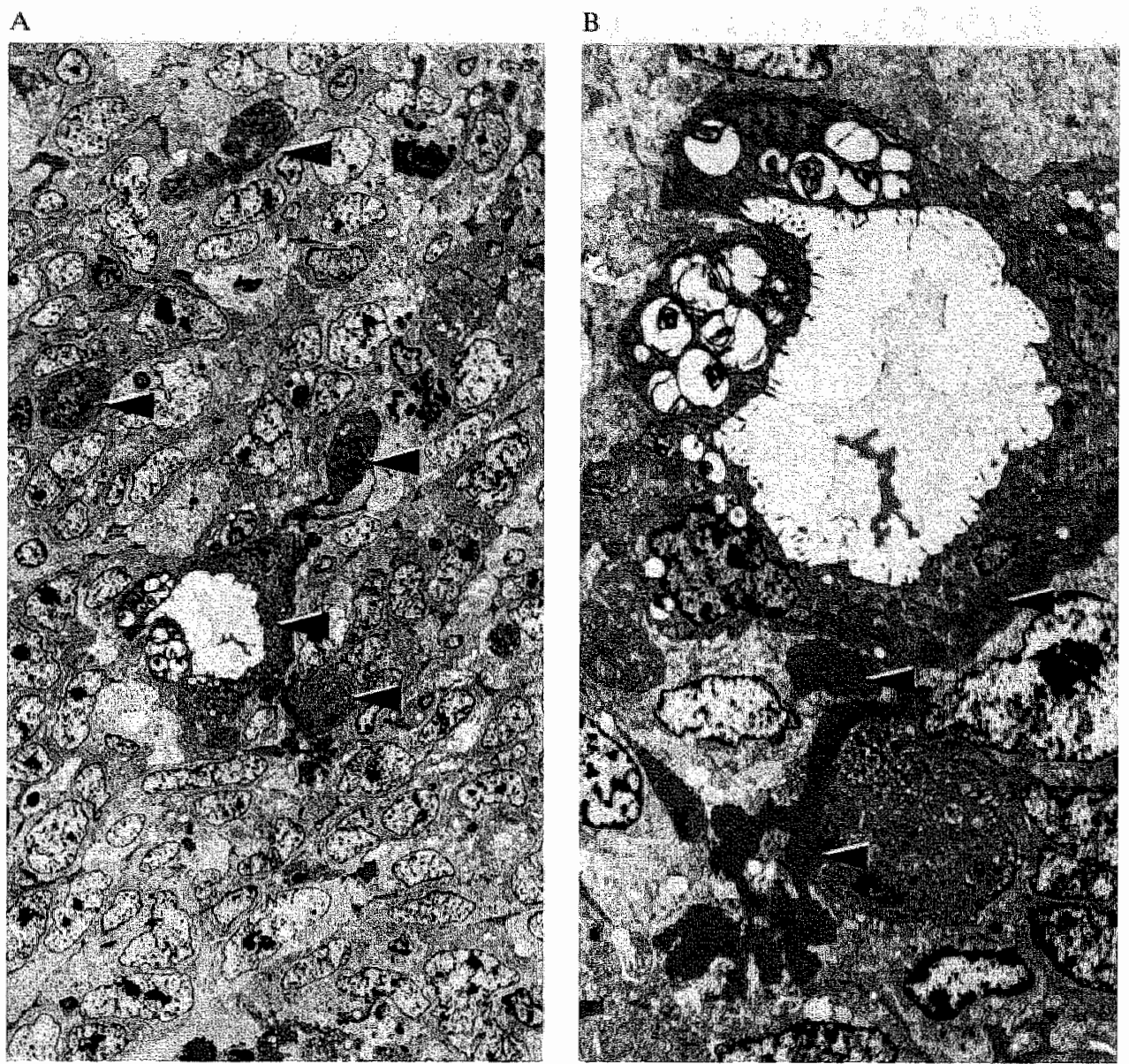

Fig $10 \mathrm{~A}$. Survey of field of tumor cells in which individual pneumocytes as well als small groups of pneumocytes with intracytoplasmic lamellar inclusions characteristic of type II pneumocytes and lumen lined with microvilli. Notice conspicuous remnants of BM (arrow heads). (A $850 \mathrm{x}, \mathrm{B}, 2900 \mathrm{x}$ ).

a search was made for tumor cells in contact with preexisting BM. Examples of tumor celis located at the stromal side of the BM surrounding trapped alveoli were readily found. Interestingly, in this situation the tumor cells exhibited a strong affinity for the BM and formed hemidesmosomes with it, despite the fact that the tumor cells were located at the "wrong" side of the BM (Fig 11).

The spindle cells present in the stroma had all the characteristics of myofibroblasts, i.e., an extensive rough endocytoplasmic reticulum occupying the central cytoplasm and large or small microfilaments arranged along the cell periphery (9). Part of the cell surface was covered by BM-like structure. Other areas, however, were associat- 


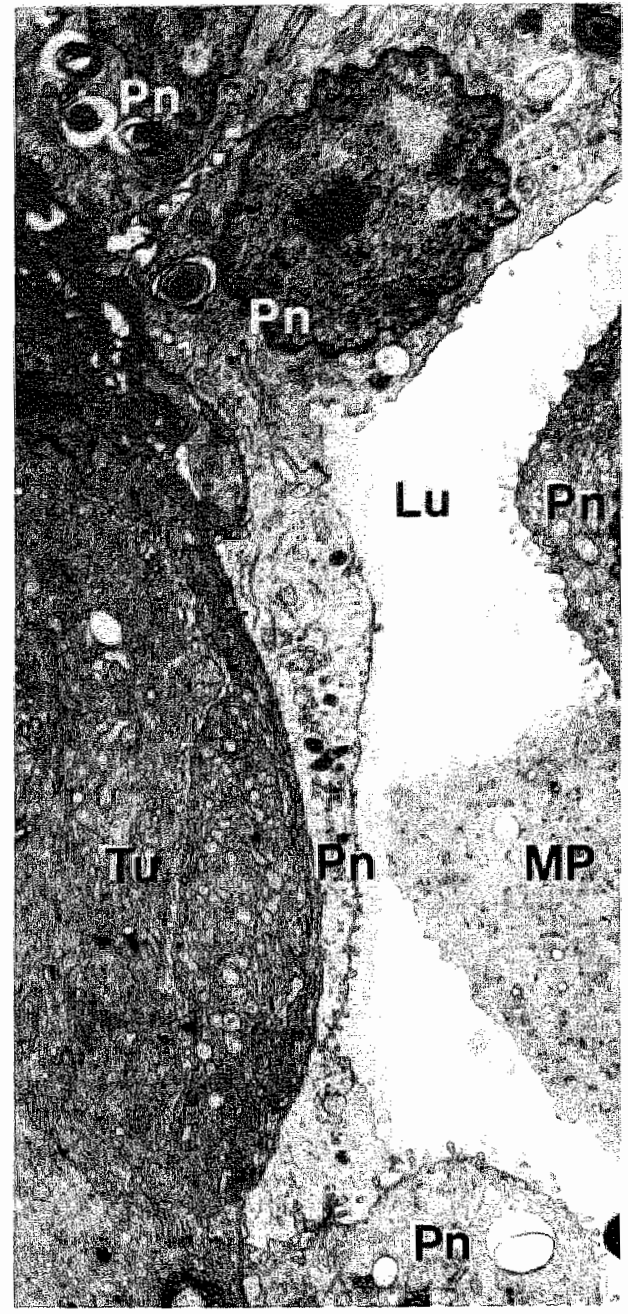

A

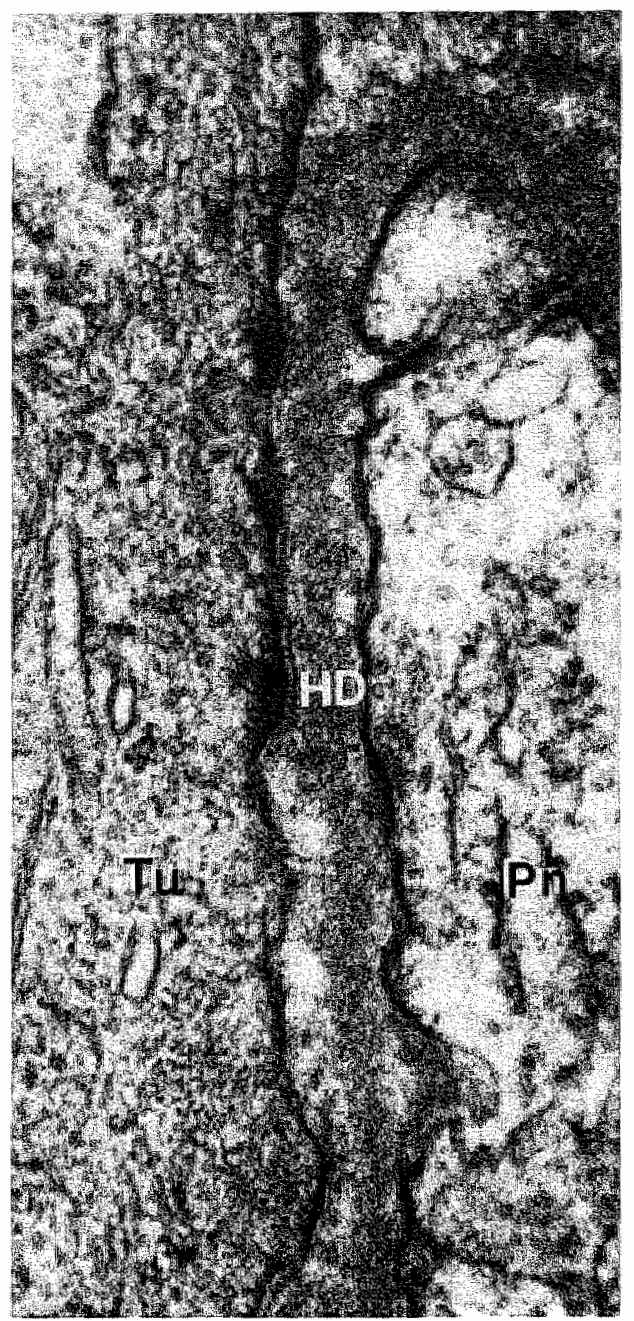

$B^{n}$

Fig 11. In this particular tumor, surface of tumor cell was virtually devoid of BM, whereas trapped preexistent alveoli had complete BM. A illustrates area where tumor cells (Tu) are situated next to trapped alweolus lined by pneumocytes (Pn). Lu, collapsed alveolar lumen; MP, alveolar macrophage. Detail enlarged in B shows that tumor cells and preumocytes are separated by continuous BM. Small hemidesmosomes (HD) connect tumor cell to BM. (A 4400x, B, 100000x). 
ed with irregular, flocculent deposits or were directly exposed to the surrounding stroma (Fig 12). Immuno-electron microscopy demonstrated that these deposits contained type IV collagen (Fig 7), but the labelling was weaker and far more urregular than that found on epithelial, tumoral, and vascular BM.

\subsection{DISCUSSION}

The present study corroborates recent ultrastructural findings $(8,9)$. Both electron microscopy and immunohistochemistry allow reliable evaluation of BM patterns in lung cancer. Immunohistochemical evaluation of BM has the advantage that large areas of the tumors can be studied. In electron microscopy, on the other hand, individual cells and the intercellular relationships can be identified with better detail. The combination of both techniques is a powerful tool in the study of invasive growth. Electron immunohistochemistry may answer questions regarding the decreased synthesis of BM constituents by tumor cells or by adjacent myofibroblasts or other stromal cells. Evaluation of the role of enzymes active in degradation of $\mathrm{BM}$ and other extracellular matrix components, using specific antibodies to these enzymes in electron immunohistochemistry, may further help to elucidate the complex events resulting in invasive growth.

Discontinuity of BM is a characteristic of the tumor-cell stroma interface in most carcinomas $(3,4)$. Tumor cells gain access to adjacent stroma through the BM, either by means of BM degradlation with the help of specific enzymes (e.g. type IV collagenase), or by defective deposition of BM at the tumor-stromal border. If $\mathrm{BM}$ degradation exceeds BM deposition, interruptions occur. Strikingly, however, in some invasive carcinomas almost continuous BM have been observed $(19,20)$. In primary and metastatic carcinomas of the lung, the adjacent alveolar parenchyma is invaded by tumor cells. Migration and growth of tumor cells into the intraalveolar compartment is not comparable to invasive growth in solid organs because of the absence of connective tissue. Tumor cells were found to interact with the alveolar tissue elements in a remarkably organized way (8): ultrastructurally, junctional complexes occurred between intra-alveolar tumor cells and neighboring pnetmocytes. Furthermore, tumor cells were connected to the alveolar BM by hemidesmosomes. Only small protrusions of tumor cells through the alveolar BM could be detected, but frankly invasive growth into alveolar septa was absent. Immunohistochemistry confirmed the persistence of an alveolar tissue architecture in the tumor periphery, characterized by continuous alveolar BM, and absence of invasive growth into alveolar septa. Our immunohistochemical and ultrastructural findings therefore imply that at the tumor periphery expansive intra-alveolar tumor growth occurs, without overt signs of invasive growth and consequently retention of preexisting alveolar structures. For their metabolic needs tumor cells depend on diffusion of nutrients and oxygen from the vessels in the alveolar wall. Consequently the tumor cores in the alveoli often were necrotic, presumably due to nutritional depri- 


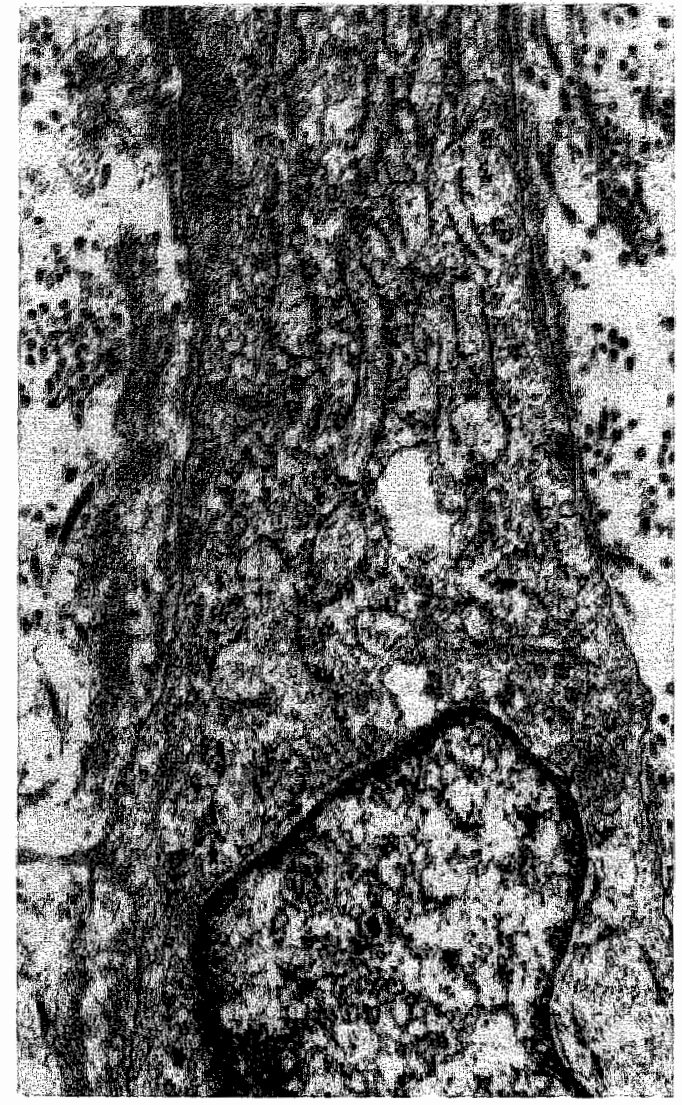

Fig 12. Stromal myofibroblasts with irregular BM-like material along surface $(26000 \mathrm{x}$ ).

vation. In the center of the tumors a totally different pattern was found. Usually an extensive desmoplastic reaction was present without remnants of the preexisting alveolar tissue pattern and furthermore, BM staining patterns were highly variable; some cases had almost a continuous BM whereas others completely lacked a BM. Desmoplasia is a local response to the presence of tumor cells in the interstitial stroma and is characterized by excessive accumulation of stromal elements. Tumor cells might produce soluble factors that elicit a chemotactic and mitogenic response of fibroblasts or myofibroblasts (21). Alternatively, proliferation of (myo)fibroblasts may be caused primarily by the fibrin deposited in the tumor periphery (22). The predominance of the myofibroblast in tumor desmoplastic reaction has been abserved in a variety of neoplasms (23-26), especially at the site of invasive growth (25, 26). These observations suggest that desmoplasia might be a reaction to invasive growth. In line with this assumption we found BM deposition in desmoplastic areas to be highly variable and discontinuous. In a recent study Barsky et al (27) demonstrated in a syngenic mouse melanoma model that treatment of the animal with 
L-3,4-dehydroproline, which blocks the formation of collagen, leads to increased incidence of metastasis. Microscopically in these animals the desmoplastic reaction to the tumor appeared to be strikingly reduced. These results strongly suggest the existence of a stromal defence mechanism against tumor invasion and subsequent metastasis. Dvorak et al (22), however, reported that collagen synthesis is a relatively late event in the desmoplastic reaction. In our opinion, the temporal discordance between collagen synthesis and invasion and metastasis does by no means rule out a positive influence of early desmoplasia on these precursors.

A relationship between the grade of differentiation and the amount of BM deposition at the tumor/stromal border in the central regions of the tumors was not found. However, the number of studied cases was too low for reliable statistical analysis. For this reason we have extended the number of cases and will report about the relation between grade of differentiation and BM deposition in the future. Immunohistochemical studies of collonic adenocarcinomas revealled an almost complete lack of BM in poorly differentiated tumors and extensive BM deposition in well differentiated tumors $(5,28)$. In contrast to these findings, we did not find a significant correlation between the degree of differentiation and $\mathrm{BM}$ deposition in colorectal carcinomas in a recent study (6).

We conclude that electron microscopic and immunohistochemical studies of the role of BM in invasive tumor growth in the lung yield comparable and reliable results. The periphery of bronchogenic squamous cell carcinoma shows expansive growth only, invasive growth being restricted to the tumor center. Myofibroblasts might play a crucial role in the desmoplastic reaction in the tumor center. Finally the occurrence of seemingly intracytoplasmic BM immunoreactivity is probably caused by engulfment of BM by tumor cells.

\subsection{REFERENCES}

1. Roos E. Cellular adhesion, invasion and metastasis. Biochim Biophys Acta 1984; 738: 263-2844.

2. Liotta LA, Rao CN "Barsky SH. Tumor invasion and the extracellular matrix. Lab Invest 1983; 49: 636-649.

3. Barsky SH, Siegal GP, Jannotta $\mathbb{F}$, Liotta LA. Loss of basement membrane by invasive tumors but not by their benign counterparts. Lab Invest. 1983; 49: 140-147.

4. Bosman FT, Havenith MG, Cleutjens JPM. Basement membranes in cancer. Uttrastruc Pathol $1985 ; 8: 291-304$

5. Burtin $P$, Chavanel $G$, Foidarl JM, Martin E. Antigens of the basement membrane and the peritumoral stroma in human colonic adeno carcinomas: An immunofluorescence study. Int J cancer 1982; $30: 13-20$.

6. Havenith MG, Arends JW, Simon REM, Volovics A, Wiggers T, Bosman FT. Type IV collagen 
immunoreactivity in coloretel cancer: prognostic value of basement membrane deposition. Accepted for publication in Cancer.

7. Weibel ER, Gill J. Siructure-function relationships at the alveolar level. Edited by JB West. Marel Deklker. New York $1977 \mathrm{pl}$.

8. Dingemans KP, Mooi WI. Invasion of lung issue by bronchogenic squamous-cell carcinomas: interactions of tumor cells and lung parenchyma in the tumor periphery. Int I Cancer 1986,37 : $11-19$.

9. Dingemans KP, Mooi WJ. Ultrastructure of tumor invasion and desmoplastic response of bronchogenic squamous cell carcinoma. Virchows Arch (Cell Parhol) 1987, 411: 283-291.

10. Ozello L. Speer FD. The mucopolysaccharides in normal and diseased breast: their distribution and significance. Am I Clin Pathol 1958; 34: 993-1009.

11. Apaja-Sarkkinen, Alavakko M, Kartunen $\mathrm{T}$, Autio-Harmainen $\mathrm{H}$. Basement membrane proteins in the spleen: immunohistochemical localization and relation to reticulin. Histopathol 1986 ; 10: $295-302$.

12. Foidart JM, Bere EW, Yaar JRM et al. Distribution and immuno-electron microscopic localization of daminin, a non collagenous basement membrane glycoprotein. Lab Invest 1980; 42: 336-342.

13. Martinez-Hernandez $A$, Marsh CA, Horn JF, Munoz E. Glomerular basement membrane: lamiina rara, Jamina derisa. Renal Physiol 1981; 4: 137-144.

14. Albrechtsen $R$, Nielsen $M$, Wewer U, Engwall $E$, Ruoslahti $E$. Basement membrane changes in breast cancer detected by immunohistochemical staining for laminin. Cancer Res $1981 ; 41$ : 5076-5081.

15. Sakai LY, Engwall E, Hollister DW, Burgeson RE. Production and characterization of a monodonal antibody to human type IV collagen. Am I Pathol 1982; 108: 310-318.

16. Muller LL, Jacks TJ. Rapid rehydration of samples for electron microscopic examinations. J Histochem Cytochem 1975; 23: 107-110.

17. Havenith MG, Cleutjens JPM, Beek C, v.d. Linden E, de Goeij AFPM, Bosman FT. Human speciffc anti type IV collagen monoclonal antibodies, characterization and immunohistochemical application. Histochern 1987; 87: 123-128.

18. Orkin RW, Gehron P, McGoodwin EB, Martin GR, Valentine $T$, Swarm R. A murine tumor producing a matrix of basement membrane. J Exp Med 1977; 145: 204-220.

19. Carter RL, Burman JF, Barr L, Gusterson BA. Immunohistochenical localization of basement membrane type IV collagen in invasive and metastatic squamous carcinomas of the head and neck. J Pathol 1985; 147: 159.164.

20. Dingemans KP. What's new in ultrastructure of tumor invasion in vivo. Path Res Pract in press.

21. Liotia LA, Rao NC, Wewer UM. Biochemical interactions of tumor cells with the basement membrane. Ann Rev Biochem 1986; 55: 1037-1057.

22. Dvorak HF. Tumors: wounds that do not heal. Similarities between tumor stroma generation and wound healing. New Eng J Med 1986; 315: 1650-1659.

23. Tremblay G. Stromal alspects of breast carcinoma. Exp Mol Pathol 1979; 31:248-260.

24. Dvorak HF, Dvorak AM, Manseau EJ, wiberg L, Churchill WH. Fibrin gel investment associated whth the 1 and 10 solid tumor growh, angiogenesis and fibroplasia in guinea pigs. Role of cellular immunity, fibroblasts, microvascular damage and infarction in line I tumor regression. N Nail Cancer Inst 1979: 62: 1459-1472.

25. Seemayer TA, Lagact R, Schürch W, Tremblay G. Myofibroblasts in the stroma of invasive and metestat ic carcinoma. Am J Surg Pathol 1979; 3: 525-533.

26. Ohtani $H_{n}$ Sastino N. Myofibroblasts and myoepithelial cells in human breast carcinoma. An ultrastructural study. Virchows Arch (Pathol Anat) 1980; 385:247.261.

27. Barsky SH, Gopalakrishna. Increased invasion and spontaneous metastasis of BL6 melanoma with inhibition of the desmoplastic response in C57 BL/6 Mice. Cancer Res 1987; 47: 1663-1667.

28. Forster SU, Talbot $I C$. Critchley DR. Laminin and fibronectin in rectal adenocarcinoma: relationship to tumor grade, stage and metastasis. British J Cancer 1984; 50:51-60. 


\section{CHAPTER 6}

\section{Basement membrane deposition in benign and malignant nevo- melanocytic lesions: An immunohistochemical study with antibodies to basement membrane components. *}

\subsection{INTRODUCTION}

During the complex processes involved in tumor invasion and metastasis, tumor cells have to traverse extracellular matrix barriers. Basement membranes (BM) form the boundary between the epithelial compartment and adjacent stroma. Transition from in situ to invasive carcinoma implies BM breakdown and passage of tumor cells through the BM (1). The situation is even more complex, however, as interactions between tumor cells and extracellular matrix can also result in induction of matrix synthesis by stromal cells and production of matrix components by tumor cells (2). Since the development of specific antibodies to BM components, reliable light microscopic immunohistochemical visualization of BM is possible. Immunohistochemical staining of BM has proved to be helpful to differentiate between benign and malignant lesions: discontinuities usually being limited to malignant lesions $(1,3)$. However, exceptions have been found to this rule: BM discontinuities do occur in benign neoplasms and conversely, intact BM have been reported in malignant tumors (3). Furthermore, inflammatory infiltrate adjacent to BM may be responsible for $\mathrm{BM}$ discontinuities (4).

The diagnosis of nevo-melanocytic lesions is often a probllem in diagnostic histopathology. The distinction between nevocellular nevi, dysplastic nevi and malignant melanoma may be difficult $(5,6)$. Juvenile melanoma for example is a benign lesion, which morphologically resembles malignant melanoma (5). Assessment of the depth of invasion is prognostically important $(7,8)$ but, especially in the presence of inflammatory infiltrate, it can be difficult. Angioinvasive growth is another prognostic indicator but its assesment is complicated by artefacts due to tissue shrinkage by fixation and embedding. The use of BM immunohistochemistry may provide (partial) solutions to these problems.

Using reticulin impregnation (Gordon and Sweet method) it was reported that completely intact BM occur around benign nevo-melanocytic lesions. However, in borderline cases reticulin staining appeared to be of little diagnostic use $(9,10)$. One of the reasons may be that reticulin impregnation, besides $B M$, also stains other structural proteins (11). Alternatively, BM deposition in nevocellular nevi and malignant melanomas has been studied at the ultrastructural level (12). Furcher-

* Havenith MG, van Zandwoort EHM, Cleutiens JPM, Bosman FT.

Submitted to Histopathology. 
more, two immunohistochemical studies on nevo-melanocytic lesions, using antibodies to BM components have been published $(13,14)$. One of these studies reportad a complete lack of immunoreactivity to BM components in $50 \%$ of malignant melanomas (13). The other study, however, reported BM immunostaining in all cases, althought to a variable extent (14). BM discontinuities could be observed sporadically in some benign lesions in both studies. Reviewing these studies, it seems that the pattern of BM deposition in nevo-melanocytic lesions is not an unequivocal discriminator between benign and malignant lesions.

To clarify the conflicting results in the literature, we studied a series of nevomelanocytic lesions by immunohistochemistry, using antibodies to the BM components type IV collagen and laminin. In addition to assessing the integrity of the BM we looked for characteristic staining patterns, which could be helpful in distinguishing between benign and malignant lesions. Also the use of BM immunostaining in the detection of angioinvasive growth was studied. Furthermore the influence of the inflammatory infiltrate in BM deposition was analyzed. Finally, we compared BM deposition in the metastasis of malignant melanomas with BM staining in the primary tumors.

\subsection{MATERIAL AND METHODS}

\subsubsection{Case material}

From the files of our department 55 cases of malignant melanoma and 45 cases of benign nevo-melanocytic lesions were collected randomly (Table I and II). Metastases of malignant melanomas were also included in this study. Malignant melanomas were classified in conformity with the revision of the Sydney classification (15).

\section{Table I}

Malignami melamoma with

adjacent componemt of:

\begin{tabular}{llcc}
\hline & type & cases & metastases \\
\hline I: & superficial spreading type & 22 & 1 \\
II: & lentigo maligna type & 5 & 1 \\
III: & acral lentigenous type & 6 & - \\
IV: & mucosal lentiginous type & - & - \\
V: & no adjacent component & & 3 \\
VI: & of unclassifiable histogenetic type & 13 & 1 \\
\hline & & 9 & 6 \\
\hline
\end{tabular}


Benign nevo-melanocytic lesions: \# cases

1. lentigo simplex 5

2. lentigo senilis 5

3. junction nevi 5

4. compound nevi 5

5. dermal nevi 5

6. halo nevi 5

7. juvenile melanoma 5

8. dysplastic nevus 5

9. blue nevus 5

Tolal \# 45

\subsubsection{Immunohistochemistry}

All tissue specimens were routinely fixed in $4 \%$ formaldehyde and embedded in paraffin. Paraffin sections were deparaffinized, rehydrated, blocked for endogenous peroxidase activity with $0.3 \% \mathrm{H}_{2} \mathrm{O}_{2}$ in methanol and washed $3 \times 5 \mathrm{~min}$ in PBS. Subsequently tissue sections were incubated with $6 \mathrm{M}$ guanidine- $\mathrm{HCl}$ in $50 \mathrm{mM}$ Na-acetate pH 6.5 as described extensively elsewhere (16), washed $3 \times 10$ min with PBS and incubated with $0.1 \%$ pepsin (Boehringer) in $1 \mathrm{~N} \mathrm{HCl}, 60$ min at RT. Subsequently the sections were washed $3 \times 5 \mathrm{~min}$ in PBS and incubated with polyclonal antibodies to type IV collagen 1:200 diluted serum (diluted in PBS with 0.1\% BSA), or with polyclonal antibodies to laminin diluted 1:100 in (PBS with $0.1 \%$ BSA). Both antisera were raised in rabbits, immunospecificity of these antisera has been reported extensively elsewhere $(17,18)$. Visualization was realized by an indirect immunoperoxidase technique with diaminobenzidine- $\mathrm{H}_{2} \mathrm{O}_{2}$ or in heavily pigmented lesions with aminoethylcarbazole as substrate. The intensity of diaminobenzidine precipitate was enhanced by adding imidazol to the substrate.

\subsection{RESULTS}

\subsubsection{Immunohistochemistry}

The reliability of the immunostaining was judged in the adjacent normal skin, which had to show staining of BM of the epidermis, skin appendices, vessels and nerves in order to be accepted. To expose the antigenic sites for the polyclonal antisera to type IV collagen and laminin in neutral buffered formaldehyde fixed and paraffin embedded tissues, pepsin digestion was used. In the majority of the studied spectmens, however, the obtained immunoreactivity was not sufficient. The im- 

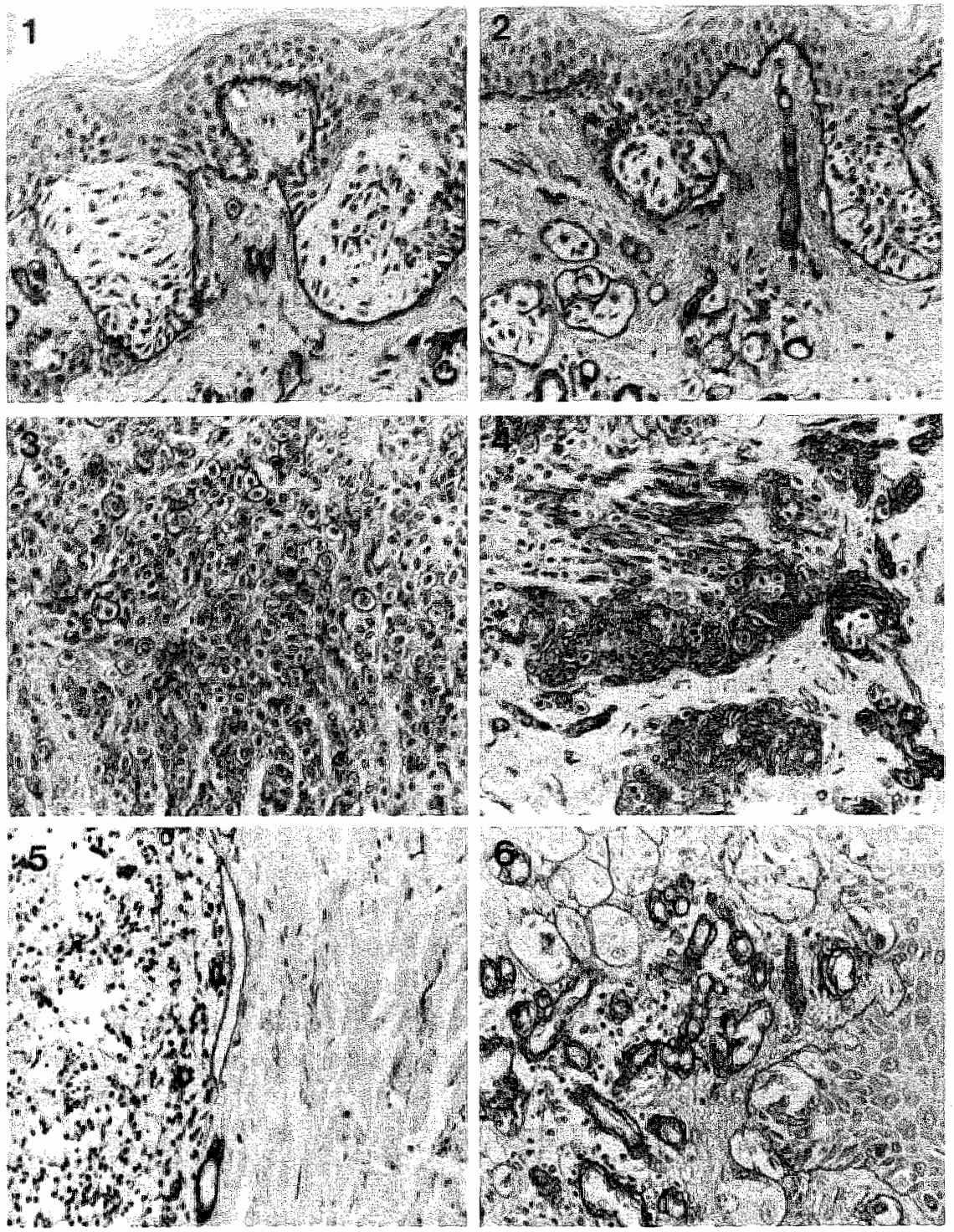

Fig. 1-15. Paralfin sections of nevo-melanocytic lesions reacted with polyclonal anti type IV collagen antibodies (immunoperoxidase).

Fig. 1 . Continuous BM at the epidermaludermal junction in a junction nevus (235x).

Fig. 2. Compound nevus: intercellular BM deposition in dermal cell nests $(235 \mathrm{x})$.

Fig. 3. Dermal nevus: pericellular BM deposition with a variable intensity $(235 \mathrm{x})$.

Fig. 4. Dermal nevus with BM deposition around spindle cells(235x).

Fig. 5. Halo nevus with rests of BM within the inflammatory infiltrate as well as the adjacent dermis $(235 x)$.

Fig. 6. Juvenile melanoma: small cell nests surrounded by a BM and intercellular BM deposition $(235 \mathrm{x})$. 
munoreactivity could be completely restored by preincubation with $6 \mathrm{M}$ Guandine$\mathrm{HCl}$ in $50 \mathrm{mM} \mathrm{Na}$-acetate buffer $\mathrm{pH} 6.5$. In general, the staining intensity with the anti laminin antiserum was identical to that with the anti type IV collagen antiserum, but somewhat weaker. Laminin reactivity could not be restored in all the tissue specimens.

\subsubsection{Benign nevus cell tumors}

In lentigo simplex and lentigo senilis the epidermal BM showed complete continuity with BM staining for type IV collagen and laminin, comparable to that in normatl skin.

Junction nevi showed large cell nests in the basal part of the epidermis, which were totally enclosed by the continuous epidermal BM (Fig 1). However, there was some variation in the intensity of the epidermal BM staining (Fig 1). Intercellular immunostaining could not be observed within the nevus cell nests. Compound nevi also showed a continuous epidermal BM with some variability of staining intensity. Nevus cell nests just below the epidermal BM were surrounded by a continuous BM (Fig 2). In contrast to the intra-epidermal cell nests, the dermal cell nests showed intercellular immunoreactivity (Fig 2). Smaller cell nests, also surrounded by a continuous BM were in the majority of cases located in the deeper parts of the dermis and showed less intercellular immunoreactivity. In dermal nevi, the larger cell nests with intercellular immunoreactivity were, as in compound nevi, mostly located just below the continuous epidermal BM. Individual nevus cells, which were also detected in compound nevi, showed a pericellular immunoreactivity, highly variable in intensity and even occasionally multilayered (Fig 3). Nevus cells with pericellular immunoreactivity were mostly located in peripheral parts of the lesions, deep in the dermis. They were surrounded by stroma, or lay close together, resembling peripheral nerve tissue, or arrector pili muscle (Fig 4). Junction, compound and dermal nevi showed, at the site of lymphocytic infiltrate, sporadically slightly discontinuous BM. Halo nevi lacked, at the site of intense lymphocytic infiltrate, any immunoreactivity to BM components at the border of nevus cells, and showed discontinuity of the epidermal BM. Rests of BM were found in the inflammatory infiltrate and also in deeper parts of the dermis between collagen fibers (Fig 5).

In juvenile melanoma, clusters of nevus cells as well as multinucleated and individual nevus cells showed almost continuous but variable immunoreactivity, at the border of nevus cells and stroma (Fig 6). The clusters showed linear or sporadically granular intercellular immunoreactivity. Hyaline bodies located at the dermalepidermal junction showed also immunoreactivity for laminin and type IV collagen (Fig 7).

Blue nevi of the common type showed irregular pericellular immunoreactivity of the slender, slightly wavy cells. Between collagen fibers neighbouring these cells, BM deposition was found. In addition to these spindle cells, nevus cells with abundant 

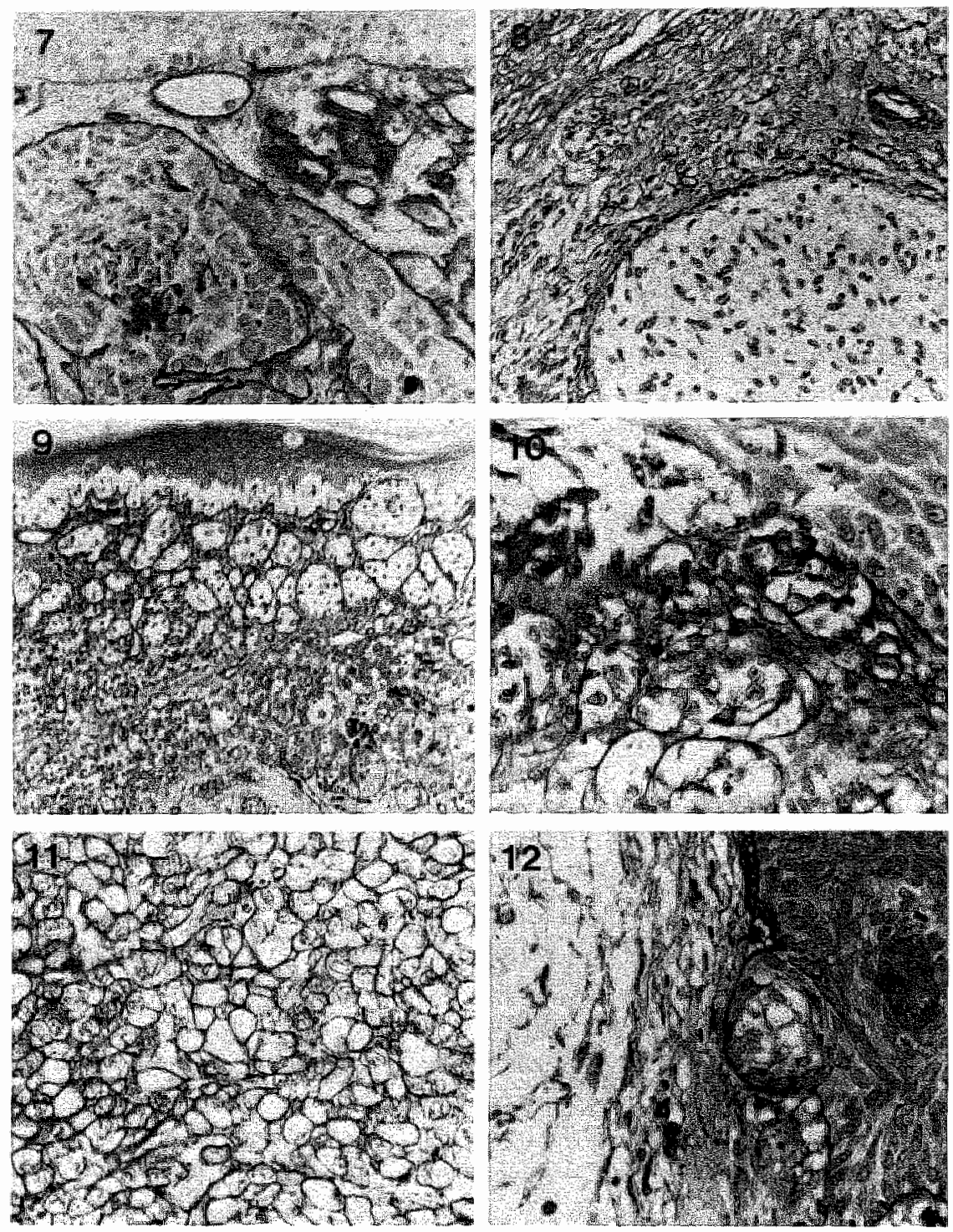

Fig. 7. Iuvenile melanoma expressing immunoreactivity at the side of the "hyaline" bodies $(235 x)$.

Fig. 8. Cellular blue nevus: the epithelial part shows only at the stromal border BM deposition, individual cells in the periphery deposit pericellular BM (235x).

Fig. 9. Superficial spreading melanoma showing large clusters the epidermal-dermal junction $(120 \mathrm{x})$.

Fig. 10. Discontinuous BM at the epidermal-clermal junction in superficial spreading melanoma $(375 x)$.

Fig. 11. Pericellular BM deposition in superficial spreading melanoma ( $375 \mathrm{x})$.

Fig. 12. Continuous BM at the epidermal-dermal junction in lentigo maligna $(375 \mathrm{x})$. 
cytoplasm and continuous pericellular immunoreactivity could be identified. Cellular blue nevi lacked in the central regions immunoreactivity, however peripheral regions showed pericellular BM deposition (Fig 8).

\subsubsection{Malignant melanoma with an adjacent component}

I: Superficial spreading type. Large clusters of tumor cells were mostly located at the dermal-epidermal junction (Fig 9). These clusters showed intercellular immunoreactivity. In contrast, intercellular BM deposition was not found in tumor cell clusters located in the epidermis. Discontinuities in the epidermal BM in the absence of inflammatory infiltrate could be detected, but varied between limited and moderate (Fig 10). At the sites of regression, the discontinuity of the BM was extensive. Pericellular immunoreactivity was detected in large tumor cell fields (Fig 11), as well as around individual tumor cells surrounded by stroma.

II: Lentigo maligna type. Specific patterns could not be detected. As in I the large cell clusters were preferentially located at the dermal- epidermal junction but small clusters were also present. In the absence of inflammatory infiltrate the epidermal BM was continuous in adjacent lentigo maligna (Fig 12). BM deposition at the junction was as in $I$.

III: Acral lentiginous type. These lesions showed identical findings as in 1 and $I 1$. The adjacent epidermis, with atypical melanocytes in the basal cell layer, showed a continuous BM.

IV: Mucosal lentiginous type was not studied.

V: No adjacent component, also designated nodular malignant melanoma. The majority of these tumors had an architecture of large fields of tumor cells (Fig 13). Especially around small vessels in these tumor cell fields inter-and pericellular BM deposition was found. However, in some tumors patterns as described in I could be identified.

VI: Unclassifiable histogenetic type. As in V, BM deposition occured mostly around large fields of tumor cells. Some tumors showed limited BM deposition in the absence of inflammatory infiltrate, mostly in the deeper parts of the tumor.

\subsubsection{Additional findings in malignant melanomas}

Tumor cell clusters surrounded by BM were found in vascular lumina (Fig 14). All metastases of malignant melanoma showed BM deposition. Comparison of the pattern in the primary tumor and metastases revealed a variation from almost identical to largely different. Very extensive BM deposition could even be detected in a lymphnode metastasis of malignant melanoma (Fig 15). 

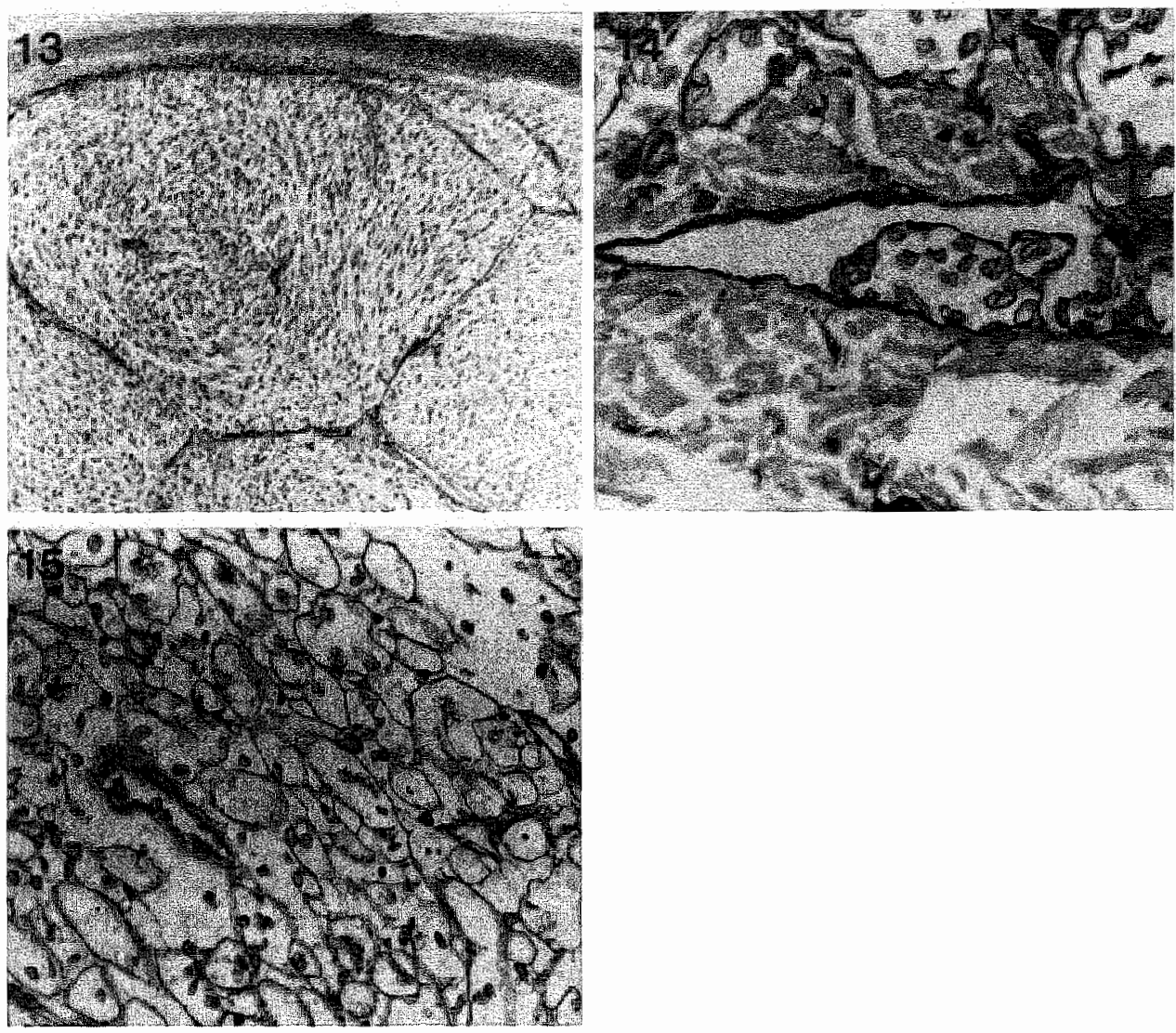

Fig. 13. Nodular malignant melanoma showing large tumor cell fields surrounded by BM (95x).

Fig. 14. Malignant melanoma cells, located in a vessel and surrounded by a BM (375x).

Fig. 15. Lymphnode metastasis of malignant melanoma: BM deposition around individual cells and small clusters (375x).

\subsection{DISCUSSION}

This immunohistological study on archival material of nevo-melanocytic lesions demonstrates that retrospective studies of BM deposition can be reliably performed, provided that appropriate treatment of tissue sections restores the immunoreactivity lost during tissue fixation and embedding. The guanidine-HCl procedure appeared to be an optimal approach with regard to type IV collagen immunoreactivity. From the point of view of tumor biology the most important finding of the present study was that in almost all nevo-melanocytic lesions BM were found at the border- 
line between nevo-melanocytic cell clusters (or even individual cells) and the surrounding connective tissue but not between keratinocytes and nevomelanocytes. In intradermal cell nests BM material was also seen between nevomelanocytes. Continuous BM were even seen around intraluminal angioinvasive melanoma cells and in lymphnode metastases of melanoma. It seems therefore that interaction with extra-cellular matrix or connective tissue stromal elements plays a dominant role in the deposition of a BM. Wether or not stromal components actually contribute to the formation of a BM, as we have recently shown in human colorectal carcinoma xenografts (19), remains to be established. It has been shown, however that murine B 16 melanoma cells are capable of in vitro production of type IV collagen and laminin (20), which indicates that the basement membranes surrounding nevomelanocytic lesions may well be a product of the tumor cells.

The biological importance for melanocytes is exemplified by the role BM play in the migration of melanocytes from the dorsal site of the neural tube to the epidermal ectoderm. This migration occurs before the BM surrounding the neural tube becomes continuous and the migrating cells remain in contact with $B M(21,22)$. Nevocellular nevi are commonly regarded as ectopic cell nests, which have failed to reach the epidermis. In gaining access to the epidermis migrating melanocytes have to pass through the epidermal BM, which subsequently closes again. The deposition of a BM around intradermal nevus cells can be regarded as a similar phenomenon. BM surrounding invasive melanoma cells, however, represent a different phenomenon. Melanocytes have to invade trough the epidermal BM and a neo-BM has to be deposited around the invading cell clusters. Around these, the BM frequently appeared to be interrupted, which was never seen in nevocellular nevi except when accompanied by inflammatory infiltrate.

It has been shown that murine melanoma cell lines with high metastatic capability have a higher tendency to produce BM degrading type IV collagen specific collagenase than melanoma cells with low metastatic capability (23). This observation would suggest that melanoma with extensive BM interruptions would show a higher incidence of metastasis than melanoma with (almost) continuous BM. Although to date we have not been able to extensively analyze this possibility we have not found any evidence to support such a correlation.

Earlier studies of BM in melanomas have yielded conflicting results. Natali et al. (13) found absence of immunoreactivity for BM components in $50 \%$ of their cases. In contrast Stenbäck et al. (14) found BM deposition in all melanomas, although to a variable extent and discontinuous. Our findings are in agreement with the latter. Almost all melanomas contained extensive BM deposition throughout, although frequently interruptions occured. Differences between tumor center and periphery, as we have reported for colonic adenocarcinomas and squamous cell carcinomas of the lung $(24,18)$, did not occur.

In connection with the histopathological diagnosis of nevo-melanocytic lesions our findings allow the following conclusions. 
1. In doubtful cases interruptions of $\mathbb{B M}$, in the absence of inflammatory infiltrate, is evidence in favor of invasive melanoma.

2. The pattern of BM deposition does not differ for the various categories of nevomelanocytic lesions and therefore is of no help in their histological classification. 3. The pattern of BM deposition does not differ for melanomas with varying levels of invasive growth and therefore offer no help in the assesment of the depth of invasion.

4. The hyaline bodies in juvenile melanoma (25) appear to consist of BM components (26), which is also illustrated by this study. BM immunohistochemistry facilitates their recognition and therefore may be of some help to distinguish between juvenile and true malignant melanoma.

5. Staining of the endothelial BM allows reliable identification of vascular structures in melanomas and facilitates the recognition of angioinvasive growth, which is regarded as an important prognostic variable.

6. Extensive deposition of BM around individual cell and cell nests in a poorly differentiated tumor of unknown origin is evidence in favor of melanoma but can never be used as conclusive evidence.

\subsection{REFERENCES}

1. Barsky SH, Siegal $\mathrm{G}$, Jannotta F, Liotia L.A. Loss of basement membrane components by invasiwe tumors but not by their benign councrparts. Lab Invest $1983 ; 49 ; 140-147$.

2. Liotta LA, Rao CN, Barsky SH. Tumor invasion and the extra-cellular matrix. Lab Invest 1983; 49: 636-649.

3. Bosman FT, Havenith MG, Cleutjens JPM. Basement membranes in cancer. Ultrastruc Pathol $1985: 8: 291 \cdot 304$.

4. Visser R, van der Beek JMH, Hawenith MG, Cleutjerts JPM, Bosman FT. Immunocytochemical detection of baterwent antigens in the histopathological evaluation of laryngeal dysplasizand neom plasia. Histopathol 1986; 10: 171-180.

5. Briggs JC. Melanoma precursor lesions and borderline melanomas. Histopathol 1985; 9 $1251-1262$.

6. Clatk WH, Elder DE, Guerry D, Epstein MN, Greene MH, van Horn M. A study of tumor progression. The precursor lesions of superticial spreading and nodular melanoma. Hum Pathol $1984 ; 15: 1147.1165$.

7. Clark WH, From I, Bernardino EA, Milum MC. The histogenesis and biologic behaviour of primary malignamt human malignant melanomas of the skin. Cancer Res 1969; 29: 705-726.

8. Breslow A. Thickness, cross-sectional areas and depth of invasion in the prognosis of cutaneous melanoma. Ann Surg 1970; 172: 902-908.

9. Briggs JC. Reticulin impregnation in the diagnosis of malignant melanoma. Histopathol 1980; 4: $507-516$.

10. McGoven VJ, Malignant melanona: Clinical and histological diagnosis. John Wiley, Chichester. 1976. 
11. Apajamarkkinen, Alavaikko M, Kartunen T, Autio-Harmainen H. Basement membrine proteins in the spleen: Immunohistochenical localization and relation to reticulin. Histopathol 1986 : 10: 295-302.

12. Curran $\mathrm{RC}, \mathrm{McCann} \mathrm{BO}$. The ultrastructure of benign pigmented naevi and melano-carcinomas in man. J Path 1976; 119:135:146.

13. Natali $\mathrm{PG}$, Nicotra $\mathrm{MR}$, Bellocei $\mathrm{M}$, Cavaliere $\mathrm{R}$, Bigotti $\mathrm{A}$. Distribution of laminin and collagen type IV in benign and malignant lesions of melanocytic origin. Int J Cancer 1985; 35: $461-467$.

14. Stänbeck F, Wasenius V-M. Occurence of basement membranes in pigment cell tumors of the skin, relation to cell type and clinical behaviour. J Cuian Pathol 1986; 13: 175 186.

15. McGovern VJ, Cochran AJ, wan der Esch EP, Little JH, Maclennan R. The classification of malignant melanoma, its histological reporting and registration: A revision of the 1972 Sydney classification. Pathol 1986; 18: 12-21.

16. Cleutjens JPM, Havenith MG, Beek. C, Vallinga M, Bosman FT. Restoration of immunoreactivity to $\mathrm{BM}$ components in routinely processed tisswes by preincubation with guanidine. $\mathrm{HCl}$ and enzymatic digestion. (Submitted to Histochemistry).

17. Havenith MG, Cleutjens JPM, Beek C, v.d. Linden E, de Goeij AFPM, Bosman FT. Human specific anti-type IV collagen monoclonal antibodies, characterization and immunohistochemical application. Histochem 1987; 87: 123-128.

18. Havenith MG, Dingemans KP, Cleutjens JPM, Wagenaar SjSc, Bosman FT. Basement membranes in bronchogenic squamous cell carcinoma: An immunohistochemical and ultrastructural study. (submitted to Ultrastruc Pathol).

19. Havenith MG, Simon SEM, Arends JW, Verstijnen C, Cleutjens JPM, Bosman FT. Origin of basement membrane type IV collagen in xenografted human epithelial tumor cell-ines. Submitted to Virchows Arch (Cell Paihol).

20. Fligiel SEG, Laybourn KA, Peters BP, Ruddon RW, Hiserodt JC, Varani J. Laminin production by murine melanoma cells: possible involwement in cell motility. Clin Exp Metast 1986: 4: 259-272.

21. Martins-Green $M$, Erickson $C A$. Dewelopment of neural tube basal lamina during neurulation and neural crest cell emigration in the trunk of the nouse embryo. J Embryol Exp Morph. 1986; 98: 219-236.

22. Erickson CA. Behawiour of neural crest cells on embryonic basal lamina. Develop Biol 1987; 120 : 38-49.

23. Liotta LA, Tryggvason K, Garbisa S, Hart 1, Folz CM, Shafie S. Metastatic potential correlates with enzymatic degradation of basement membrane collagen. Nature 1980; 284: 67-68.

24. Havenith MG, Arends JW, Simon REM, Volovics A, Wiggers T, Bosman FT. Type IV collagen immunoreactivity in colorectal cancer: Prognostic value of basement membrame deposition. Accepted for publication in Cancer.

25. Kamino H, Misheloff E, Ackerman AB, Flotte TJ, Greco MA: Eosinophilic globule's in Spitz's nevi. Am J Dermathopathol 1979; 1: 319-324.

26. Barsky SH, Hamnah JB. Extracellular hyaline bodies are basement membrane accumulations. An IClin Pathol 1987; 87: 455-460. 



\section{CHAPTER 7}

\section{General discussion}

\subsection{Introduction}

In this final chapter an attempt will be made to discuss the results presented in this thesis in a somewhat broader context than was aimed at in the discussion in the individual chapters. Two main themes will be focussed upon. Firstly, our findings in chapter 2 and 3 are discussed in connection with the general aspects of BM structure, composition and metabolism, especially in regard of tumor invasion. Secondly, the impact of BM immunohistochemistry on diagnostic histopathology is reviewed.

\subsection{BM STRUCTURE AND COMPOSITION}

The work presented in chapters 2 and 3 , illustrates that immunohistochemical identification of basement membranes (BM) forms a powerful tool in the study of cellextracellular matrix interactions. However, detection of immunoreactivity with antibodies to BM components is not conclusive evidence of the presence of a structured BM, which would require electron microscopic confirmation. Electron microscopy allows detailed structural analysis of subcellular structures, cellular interactions and extracellular matrix. The limited sample size for electron microscopy is, however, a significant disadvantage. In contrast, immunohistochemistry provides immunochemical evidence of the chemical nature of tissue structures, on relatively large samples but with little structural resolution. The combination of both techniques, immuno-electron microscopy, would significantly improve our understanding of structure and composition of BM in normal and neoplastic tissues (1-4). Another limitation of immunohistochemistry is that a positive finding only indicates the presence of the substance of interest but provides no information concerning the dynamics of production and degradation. For BM such additional information might be obtained through metabolic labelling studies, combining immunohistochemistry with autoradiographic detection of incorporated labelled precursors (5). An alternative approach would be detection of BM component specific mRNA's by hybridization histochemistry (6).

In addition to localization, application of BM component specific antibodies has facilitated studies concerning the interactions between BM component specific sites on cell surfaces and specific domains on the macromolecules which constitute the BM. By blocking well defined regions on BM molecules with monoclonal antibodies functional domains have been discovered (7). The characterization of plasma mem- 
brane associated proteins such as the laminin receptor (8-10), which specifically interact with BM and interstitial proteins has started recently. Biochemical and molecular biological studies will reveal new, possibly tissue and organ specific, constituents of BM and interstitial stroma (11-13). Subsequently monoclonal antibodies to these components will provide a tool for functional analysis of molecular domains and immunohistochemical studies using these antibodies will give more insight into their biological significance.

\subsection{BM DEPOSITION IN NEOPLASIA}

The origin of BM components has not been completely elucidated. The generally held view is that the adjacent epithelial or endothelial cells synthesize the BM constituents. However, there is substantial evidence from studies, using epithelial tumor xenografts and species specific antibodies reactive with BM components, that these components may not only be derived from the adjacent epithelium but are also deposited by stromal elements (14). Immunohistochemistry may not be the optimal approach to resolve this issue. In situ hybridization with nucleic acid probes for BM component-mRNA may be a more conclusive approach to determine exactly which cells are involved in the synthesis and deposition of epithelial BM. Coculturing experiments of fibroblasts with cancer cells might be an even more dynamic approach to solve this problem.

In general, the unraveling of the mechanisms involved in BM metabolism will be strongly facilitated by in vitro models in which BM deposition of normal and tumor cells can be studied in the presence of various types of mesenchymal elements and in various artificial collagen matrices (15). Our results with tumor cells, cultured in artificial collagen lattices has so far been discouraging, because tumor cells which after xenografting into nude mice demonstrated BM deposition could not be induced to deposit BM in vitro under a variety of conditions. Production of various $\mathrm{BM}$ components in vitro has often been detected, but only a few studies concerning assembly of BM components to a BM-like structure at the border of epithelial cells and artificial stroma have been reported (16). Additives to standard tissue culture medium, such as vitamins, growth factors, hormones, and inhibitors for BM degrading enzymes might be an approach to obtain BM deposition in vitro.

\subsection{BM AND TUMOR INVASION}

Studies on BM structure and turnover, might be important in cancer research. In vitro and in vivo manipulation of cell-extracellular matrix interactions with monoclonal antibodies to BM constituents might yield important information concerning the mechanisms involved in tumor invasion. BM in tumors are probably even more than in normal tissues dynamic structures, the immunohistochemical 
staining showing the positive balance between BM deposition and BM degradation. Degradation of BM requires specific enzymes such as type IY collagenase (17), along with many other proteases involved in this process (18). How exactly tumor cells in invasive neoplasms degrade and pass through BM has not been fully elucidated. Similarly, how intravascular potentially metastasizing tumor cells lodge at the metastatic site and cross the local BM, before they reach the interstitial compartment in distant organs has not been elucidated. In vitro and vivo studies of the passage of leukocytes through BM might be a readily available model and as such be helpful in unraveling the role of BM degrading enzymes during the passage of cells through a BM (19).

Activators and inhibitors of degrading enzymes presumably are involved in the regulation of BM degradation (20). BM degrading enzymes have been isolated from tumors and their metastases as well as from tumor cell-lines. High levels of these enzymes correlated with increased invasive and metastatic capability $(21,22)$. Specific antibodies to BM degrading enzymes might serve to identify specifically which cells are involved in the invasive process (23), assuming that not all cells in a malignant meoplasm have invasive capacities. Such studies, however, will not reveal the influence of interstitial stromal elements on the turnover of BM. On the whole the role of stromal elements in the invasive process appears to be underrated.

\subsection{BM IMMUNOSTAINING IN DIAGNOSTIC HISTOPATHOLOGY}

In the second part of this general discussion we will review the significance of $\mathrm{BM}$ immunohistochemistry for diagnostic histopathology of neoplasia. Conventionally, $B M$ visualization has been achieved through application of staining techniques such as reticulin silver impregnation or PAS staining. These techniques, however, are not specific for BM structures. Reticulin stains impregnate reticulin fibers as well as BM whereas PAS staining demonstrates all glycoproteins, including most BM components (24). In recent years the conventional histochemical stains have been replaced by $\mathrm{BM}$ immunostaining, using monospecific antibodies against type IV collagen and laminin. An important potential application would be the distinction between invasive and non invasive neoplastic lesions, which is a major problem in diagnostic histopathology. Based upon a large number of observations it can be concluded that in general normal epithelia as well as dysplastic and borderline non-invasive lesions display a continuous BM, whereas in invasive carcinomas BM are discontinuous (23, 25). This difference can not be used in lesions with an intense inflammatory infiltrate, which is also accompanied by discontinuities of the BM (26). Assessment of invasive growth by $\mathrm{BM}$ immunostaining appears to be more helpful in neoplastic lesions originating in surface epithelia than in the epithelium of parenchymatous organs. Especially in non invasive lesions of the breast, urinary bladder, uterine cervix, and squamous epithelia BM immunostaining is of diagnostic importance (25, 27). However, BM discontinuity may never be used as a single decisive criterium of 
invasive growth. Highly differentiated squamous cell carcinomas usually deposit continuous BM and, conversely, inflammatory infiltrate can produce discontimuities in non invasive lesions through degradation of the BM presumably by proteases released by leukocytes. In the presence of inflammatory infiltrate, therefore, it may be impossible to distinguish between carcinoma in situ and invasive carcinoma. Another example of a frankly invasive neoplasm which nevertheless can be demarcated by a continuous BM is malignant melanoma (28).

BM immunostaining can also be useful for the determination of the nature of poorly differentiated tumors. In the absence of BM deposition at the border of tumor cells and surrounding connective tissue, a dliagnosis of carcinoma or of sarcoma, originating from cells which are normally surrounded by a BM such as Schwann cells, muscle cells and fat cells, is rather unlikely. There are, however, exceptions to this general rule. Poorly differentiated leiomyosarcoma and monophasic (fibrous) synovial sarcoma may lack any immunoreactivity to BM constituents (29). Nevertheless pericellular immunoreactivity appears to be a characteristic of soft tissue tumors originating from cells which are normally surrounded by $\mathrm{BM}$. More specifically, fibrosarcomas and malignant fibrous histiocytomas are characterized by the complete absence of BM immunoreactivity (29).

A non-specific but nevertheless rather useful feature of BM immunostaining is its elucidation of the architectural characteristics of a tumor. The architecture in papillary, tubular or alveolar patterns can be readily identified, even in necrotic areas and the pattern of tumor vascularization can also be easily visualized. This latter feature facilitates the recognition of angio invasive growth. Although lymph capillaries show a discontinuous BM or are totally devoid of BM larger lymph vessels deposit a continuous subendothelial BM. Because lymph capillaries lack immunoreactivity with antibodies to factor VIII, BM immunostaining may assist in the recognition of lymph vessels. Blood capillaries, however, are clearly demarcated by BM immunohistochemistry which make them more readily recognizable than by immunostaining with antibodies to factor VIII (30).

Some neoplasms can be recognized by a characteristic pattern of BM immunostaining. A typical example is the occurrence of extracellular hyaline bodies in adenoid cystic carcinoma, endodermal sinus tumor, juvenile melanoma and odontogenic cysts which express immunoreactivity with antibodies to type IV collagen and laminin (31). Furthermore, in adenoid cystic carcinoma extremely thick BM deposits occur around tumor cell nests (32).

\subsection{CONCLUDING REMARKS}

The future will tell what role antibodies to BM specific antigens will ultimately play in the routine histopathological diagnosis of neoplastic lesions. It is beyond doubt, however, that the study of the structure, composition (including identification of new cell- and tissue specific BM components) and metabolism of the BM and its in- 

in the elucidation of the significance of the extracellular matrix for normal and neoplastic cellular behaviour.

\subsection{REFERENCES}

1. Laurie GW, Leblond CP, Inoue S, Martin GR, Chung A. Fine structure of the glonerular basement membrane and immunolocalization of five basement membrane components to the lamina densa (basal lamina) and its extensions in both glomeruli and tubules of the rat kidney. Am . Anat 1984; 169: 463-481.

2. Foidart JM, Bere EW, Yaar M, Rennard SI, Gullipo M, Martin GR, Katz SI. Distribution and immunomelectron microscopic localization of laminin, a noncollagenous basement membrane glycoprotein. Lab Invest $1980 ; 42: 336-342$.

3. Stow JL, Sawada H, Farquhar MG. Basement membrane heparan sulfate proteoglycans are concentrated in the laminae rarae and in podocytes of the rat glomerulus. Proc Natl Acad Sci USA $1985 ; 82: 3296-3300$.

4. Martinez-Hernandez A, Chung AE. The ultrastructural localization of two basement membrane components: Entactin and laminin in rat tissues. J Histochem Cytochem 1984:32:289-298.

5. Price RG, Spiro RD. Studies on the metabolisn of the renal glomerular basement membrane. $J$ Biol Chem 1977; 252: 8597-8602.

6. Boot-Handford RP, Kurkinen M, Prockop DJ. Steady-state levels of mRNAs coding for the type IV collagen and laminin polypeptide chains of basement membranes exhibit marked tissuespecific stoichiometric variations in the rat. J Biol Chem $1987 ; 262$ : 12475-12478.

7. Chiu AY, Matthew WD, Patterson PH. A monoclonal antibody that blocks the activing of a neurite regeneration-promoting factor: studies on the binding site and its localization in vivo. J Cell Biol 1986; 103: 1383-1398.

8. Rao NC, Barsky SH, Terranowa VP, Liotta LA. Isolation of a tumor cell laminin receptor. Biochem Biophys Res Commun 1983; 111: 804-808.

9. von der Mark K, Kühl U. Laminira and its receptor. Biochim Bioplyys Acta 1985; 823: 147-160.

10. A.umailley M, Nurcombe V, David E, Paulsson M, Timpl R. The cellullar interactions of laminin fragments: Cell adhesion correlates with two fragment-specific high affinity binding sites. J Biol Chem 1987; 262: $11532-11538$.

11. Leu F., Engvall E, Damjanov 1. Heterogeneity of basement nembranes of the human genitourimary tract revealed by sequential immunofluorescence staining with nonoclonal antibodies 10 laminin. J Histochen Cytochem 1986; $34: 483-489$.

12. Ohno $M$, Martinez-Hernandez A, Ohno $N$, Kefalides $N A$. Laminin $M$ is found in placental basement membranes, but not in basement membranes of neoplastic origin. Connnec Tis Res 1986; 15: $199-207$.

13. Michael AF, Yang J-Y, Falk RJ, Bennington MJ Scheinmann II, Vernier RL, Fish AJ. Monoclonal antibodies to humar renall basement membranes: heterogenic and ontogenic changes. Kidney Int 1983; 24: 74-86.

14. Damjanow 1, Damjanov M, Knowlless BB, Engvall E. Origin of laminin in the extracellular matrix of human tumor xenografts in nude mice. Virch Areh (Cell Pathol) 1985; 49: 45-52.

15. Nusgens B, Merrill C, Lapierre C, Bell E. Collagen biosynthesis by cellss in a tissue equivalent matrix in vitro. Coll Rel Res. 1984; 4: 351 364.

46. David $G$, Nusgens $B$, wan der Schueren $B$, van Cauwenberge $D$, van den Berghe $H$, Lapierc $C$. Collagen metabolism and basement membrane formation in cultures of mouse mammaryepithelial cells. Exp Cell Res 1987; 170: 402-416. 
17. Salo T, Liota LA, Tryggvason K. Purification and characterization of a murine basement mem. brane collagen-degrading enzyme secreted by metastatic tumor cells. I Biol Chem 1983; 258: 3058-3063.

18. Thorgeirsson UP, Turpenniemi-Hujanen T, Liota LA. Cancer cells, components of basement membranes, and proteolyuic enzymes. In Intemational review of experimental pathology 1985 vol 27 pag 203-233 Academic Press Inc.

19. Pipoly DJ, Crough EC. Degradation of native Iype IV procollagen by human neutrophil elastase. Implications for leukocyte mediated degradation of basement membranes. Biochem 1987; 26: 5748-5754.

20. Thorgeirsson UP, Lionta LA, Kalebic T, Margulies I, Thomas K, Russo RG. Effects of natural protease inhibitors and a chemoattractant on tumor cell invasion in vitro. J Natl Cancer Inst 1982; 69: 1049-1054.

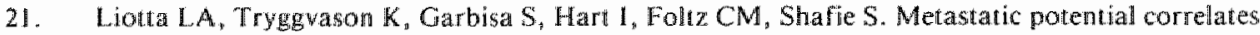
with enzymatic degradation of basement membrane collagen. Nature 1980; 284: 67-68.

22. Mullens DE, Rohrlich ST. The role of proteinases in cellular invasiveness. Biochim Biophys Acta 1983; 695: 177-2.14.

23. Barsky SH, Siegal GP, Jannotta F, Loitta LA. Loss of basement membrane components by invasive tumors but not by their benign counterparts. Lab Invest 1983; 49: 140-147.

24. Apaja-Sarkkinen, Alavaikko M, Kartunen $T$, Autio-Harmainen $H$. Basement membrane proteins in the spleen: immunohistochemical localization and relation to reticulin. Histopathol 1986; 10: 295-302.

25. Bosman FT, Havenith $\mathrm{MG}_{n}$ Cleutjens JPM. Basement membranes in cancer. Ultrastruc Pathol $1985 ; 8: 291-304$.

26. Visser R, van der Beek JMH, Haventh MG, Cleutjens JPM, Bosman FT. Immunocytochemical detection of BM antigen in the histopathological evaluation of laryngeal dysplasia and neoplasia. Histopathol 1986: 10: 1771-180.

27. Birembaut $P$, Caron $Y$, Adnet $J-J$, Foidart $J-M$. Usefulness of basement membrane markers in tumoural pathology. J Pathol 1985; 145:283-296.

28. Havenih MO, van Zandvoort EHM, Cleutjens JPM, Bosman FT. Basement membrane deposition in benign and malignant nevo-melanocytic lesions: an immunohistochemical study with antibodies to basement membrane components. submitted to Histopathology.

29. Ogawa $K$, Oguchi $M$, Yamabe $H$, Nakashima $Y$, Hamashima $Y$. Distribution of collagen type IV in sofi tissue tumors. Cancer 1986; 58: 269-277.

30. Barsky SH, Baker A, Siegal GP. Togo S, Liotta LA. Use of anti-basement membrane antibodies to diseinguish blood vessel capillaries from lymphatic capillaries. Am J Surg Pathol 1983; 7: 667.677 .

31. Barsky Sh, Hannah JB. Extracellular hyaline bodies are basement membrane accumutations. Am J Clin Pathol 1987; 87: 455-460.

32. Kallioinen $\mathrm{M}$. Immuno-electron microscope demonstration of the basement membrane components laminin and type IV collagen in the dermal cylindroma. J Pathol 1985; 147: 97-102. 
In this thesis some aspects of the interaction between tumor cells and the extra cellular matrix, as reflected in the basement membrane (BM) are studied.

Chapter 1 introduces the problem. The structure and composition of the BM is reviewed. It is emphasized that, although the biochemistry and molecular biology of the major components common to all BM, type IV collagen and laminin, have been clarified, many questions have remained unanswered. The dynamics of $B M$, for example, and the nature and function of cell or organ specific BM components are largely unknown.

In this chapter furthermore the role of BM in neoplasia is reviewed. Originally BM were regarded as static structures which were destroyed by the invading malignant tumor cells. It is now clear that tumor cells not only degrade BM components, but also deposit BM. Consequently, the patterns of BM deposition in neoplasms are the result of a dynamic balance between deposition and BM degradation. Which factors regulate this balance in neoplastic cells to date remains largely unknown.

In diagnostic histopathology immunohistochemical staining for BM components has been used to distinguish invasive from non invasive neoplasms, for the classification of soft tissue tumors, and as a prognostic indicator. In the final part of this chapter the aim of the studies described in this thesis is outlined.

Chapter 2 describes two new monoclonal antibodies reactive with human type IV collagen in frozen as well as routinely fixed and processed tissue sections. The antibodies (1042 and 1043) were raised against human placental type IV collagen and were shown by immunobloting and ELISA tests to react exclusively with type IV collagen determinants. Extensive immunohistochemical survey studies on panels of tissues from various species, using unfixed cryostat sections, demonstrated that antibody 1043 reacted only with human type IV collagen whereas antibody 1042 in addition reacted with rabbit type IV collagen. All tissues showed homogeneous staining of the basement membrane, indicating that the cletected epitopes did not show organ-specific distribution. Tissue processing protocols for using these monoclonal antibodies on routinely processed paraffin embedded tissues were developed. It was found that whereas polyclonal anti-type IV collagen antisera required pepsin digestion, our monoclonal antibodies required pronase or papain digestion to restore type IV collagen immunoreactivity in paraffin sections. It is concluded that these monoclonal anti-type IV collagen antibodies detect species specific epitopes which can be detected in routinely processed paraffin embedded tissues after appropriate enzyme pretreatment.

In chapter 3 the origin of BM at the tumor-stromal interface was studied in nude 
mouse and rat xenografts of human tumor cell-lines. Polyclonal cross-species reactive anti type IV collagen antibodies and two monoclonal human specific type IV collagen antibodies, as described in chapter 2 , were used. The xenografts were derived from a colonic adenocarcinoma (5583-S), transformed human amnionic epithelium (WISH), and a human oral epidermoid carcinoma (KB). With the crossspecies reactive anti type IV collagen antibodies, BM were identified, in the original colonic adenocarcinoma and in all xenografts, at the tumor cell stromal border as well in the tumor vasculature BM. The human specific antibodies visualized the same pattern of type IV collagen deposition in the original colonic adenocarcinoma and in xenografts of normal human colonic mucosa, whereas in xenografts of 5583-S neither at the tumor/stromal border nor in the vasculature BM immunostaining was obtained. In vitro $5583-\mathrm{S}$ cells did not produce any type IV collagen. Xenografts of WISH and $\mathrm{KB}$ cells showed discontinuous BM immunoreactivity at the tumor-stromal border with cross-species reactive as well as human specific antibodies. Vascular BM, however, failed to show immunoreactivity with human specific antibodies to type IV collagen. In vitro in these cells production of type IV collagen "including the specific human epitope, could be demonstrated. These observations strongly suggest that $\mathrm{BM}$ at the tumor/stroma interface in xenografts of 5583-S cells are of murine origin. In contrast, the BM in xenografts of WISH and $\mathrm{KB}$ cells is at least partly of human origin. Therefore, mesenchymal stromal elements appeared to be involved in the production and extracellular deposition of BM components in epithelial neoplasms.

In chapter 4 BM deposition at the tumor-stromal border was studied in 163 cases of colorectal carcinomas. Type IV collagen immunoreactivity was scored semiquantitatively as moderate/extensive versus limited and these scores were correlated with Dukes' stages and survival data. Cases with limited BM deposition showed a significantly shorter overall survival. Stratification of the cases for limited versus moderate/extensive $\mathrm{BM}$ deposition and Dukes' stages $\mathrm{A} / \mathrm{B}$ versus $\mathrm{C} / \mathrm{D}$, showed that in Dukes' stages $\mathrm{C} / \mathrm{D}$, cases with moderate/extensive $\mathrm{BM}$ deposition showed a significantly better survival than cases with limited BM deposition. Our resullts suggest that immunostaining of $\mathrm{BM}$ of cases in Dukes $\mathrm{C}$ differentiates tumors with relatively high invasive and metastatic capacity from tumors with low invasive and metastatic capacity.

In chapter 5 BM deposition at the interface of tumor cells and stroma was studied in 27 bronchogenic squamous cell carcinomas. From peripheral and central parts of the tumors, specimens were collected and frozen as well as formalin fixed and paraffin embedded. Also specimens for electron microscopy were collected. Using antibodies to type IV collagen and laminin, the BM was visualized in light microscopy, by an indirect immunoperoxidase technique. Light microscopic findings were compared to ultrastructural observations. The peripheral parts of the tumors showed continuous BM in a recognizable preexisting alveolar pattern, without evidence of invasive growth into the alveolar septa. In contrast, central parts showed 
highly variable BM deposition, ranging from continuous to almost completely absent. Alveolar patterns were not observed in the tumor center. The stromal compartment of the tumor center contained many spindle cells with irregular pericellular BM, which could ultrastructurally be identified as myofibroblasts. Electron microscopy and immunohistochemistry yielded comparable results. It is concluded that the periphery of bronchogenic squamous cell carcinomas show expansive growth. Invasive growth appears to be restricted to the tumor center.

Patterns of BM deposition were furthermore investigated in benign and malignant nevo-melanocytic lesions by BM immunostaining as described in chapter 6 . To restore the immunoreactivity with antibodies to $\mathrm{BM}$ components, paraffin sections from stored tissue blocks required pretreatment with $6 \mathrm{M}$ guanidine- $\mathrm{HCl}$ in addition to pepsin preincubation. BM deposition was found around clusters as well as individual nevo-melanocytic cells in contact with dermal stroma. However, between keratinocytes and completely intra-epidermally located nevo-melanocytic cells, BM immunostaining could not be detected. Tumor cell-stromal interaction apparently is a prerequisite for BM deposition in nevo-melanocytic lesions. BM discontinuities in the absence of inflammatory infiltrate appeared to be evidence in favor of malignant melanoma in doubtful cases. The general pattern of BM deposition in benign and malignant lesions was found to be identical and therefore of no help in differential diagnosis. Identification of hyaline bodies, which show immunoreactivity with antibodies to BM components, may be helpful to distinguish between juvenile and malignant melanomas. Detection of angioinvasion, a prognostic indicator in malignant melanoma, is facilitated by BM immunostaining. Pericellular BM deposition in cell clusters in metastasis of a poorly differentiated tumor of unknown origin argues in favor of the possibility of malignant melanoma.

In chapter 7, the results of the studies are discussed against the background of general aspects of BM in relation to tumor invasion. Finally, the significance of $\mathrm{BM}$ immunostaining for diagnostic histopathology is reviewed. 

In dit proefschrift zijn enkele gezichtspunten van de wisselwerking tussen tumor cellen en extracellulaire matrix, zoals weerspiegeld in basale membranen (BM), het onderwerp van studie.

In hoofdstuk 》wordt een overzicht van de structuur en samenstelling van de BM gegeven. Ondanks de opheldering van vele biochemische en moleculair biologische aspecten van belangrijke BM componenten zoals collageen type IV en laminine, blijven nog vele vragen onbeantwoord. Over de aanmaak en afbraak van BM is, evenals over de aard en functie van cel- en orgaan specifieke bestanddelen van de BM, weinig bekend.

Verder wordt in dit hoofdstuk een overzicht gegeven van de rol die BM spelen in neoplastische lesies. Aanvankelijk werden BM beschouwd als statische structuren die worden doorbroken door invasief groeiende maligne tumor cellen. Momenteel is duidelijk geworden dat tumor cellen niet alleen BM componenten afbreken, maar ook in staat zijn tot het afzetten van BM. Hieruit kan worden afgeleid dat de patronen waarin BM in neoplastische aandoeningen voorkomen, de resultante zijn van aanmaak en afbraak. Over de manier waarop deze evenwichts-situatie in tumoren in stand wordt gehouden is op dit moment nog weinig bekend.

In de diagnostische histopathologie wordt de immunohistochemische aankleuring van BM toegepast om invasieve van niet invasieve tumoren te onderscheiden. Verder is deze techniek van belang voor de differentiële diagnostiek van weke delen tumoren en heeft de mate van BM depositie prognostische betekenis. In het laatste gedeelte van hoofdstuk 1 wordt de vraagstelling van dit proefschrift geschetst.

Hoofdstuk 2 beschrijft twee monoclonale antilichamen gericht tegen humaan collageen type IV, die zowel toepasbaar zijn op ingevroren als op in paraffine ingebed weefsel. De antilichamen (1042 en 1043) werden opgewekt tegen uit humane placenta geisoleerd collageen type IV, de specificiteit werd aangetoond door middel van immunoblotting en ELISA. Door gebruik te maken van een weefselpanel samengesteld uit weefsels van verschillende zoogdier species kon op coupes van ingevroren niet gefixeerde weefselstukjes worden aangetoond dat de antilichamen alleen met humane weefsels reageren. Alle humane weefsels vertoonden aankleuring van $\mathrm{BM}$, waardoor orgaan specificiteit van deze antilichamen uitgesloten kon worden. Voor het verkrijgen van immunoreactiviteit in formaline gefixeerde en in paraffine ingebedde weefsels was een preincubatie met enzymen noodzakelijk. Voor het polyclonale antiserum was een pepsine digestie vereist, voor de monoclonale antilichamen pronase. Met deze monoclonale antilichamen kunnen in routinematig gefixeerde en ingebedde weefsels na enzym behandeling specifieke humane epitopen worden aangetoond. 
In hoofdstuk 3 wordt de origine van BM op het grensvlak van tumor epitheel en stroma onderzocht in xenotransplantaten van humane tumor cel lijnen in immuungecompromiteerde muizen en ratten. Hiervoor werd gebruik gemaakt van polyclonale kruisreagerende anti collageen type IV antilichamen en de twee humaan specifieke anti collageen type IV antilichamen, die beschreven werden in hoofdstuk 2 . De xenotransplantaten waren afkomstig van een adenocarcinoma van het colon (5583-S), getransformeerd humaan amnion epitheel (WISH), en een humaan plaveiselcel carcinoma (KB). Met de kruisreagerende polyclonale antilichamen tegen collageen type IV werden BM aangetoond op het grensvlak van tumor epitheel en stroma en in de vaatstructuren, zowel in het primaire adenocarcinoma van het colon als in alle xenotransplantaten. De humaan specifieke antilichamen lieten het zelfde patroon zien van $\mathrm{BM}$ depositie in het primaire adenocarcioom van het colon en in de xenotransplantaten van normale colon mucosa. Xenotransplantaten van 5583-S darantegen vertoonden geen BM op het grensvlak van tumor en stroma, ook vasculaire BM konden niet worden aangetoond. In vitro vertoonden $5583-S$ cellen evenmin aanwijzingen voor productie collageen type IV. Xenotransplantaten van WISH en $\mathrm{KB}$ cellen vertoonden echter discontinue BM immunoreactiviteit op het grensvlak van tumor epitheel en stroma met kruisreagerende en humaan specifieke antilichamen. Vasculaire BM daarentegen lieten geen immunoreactiviteit zien met humaan specifieke antilichamen tegen collageen type IV. In vitro kon in deze cellen productie van collageen type IV worden aangetoond, zelfs de humaan specifieke epitopen werden aangetoond. Uit deze waarnemingen kan worden geconcludeerd dat de BM op het grenswlak van tumor en stroma in de xenoplantaten van 5583-S van muis of rat origine zijn. BM in xenotransplantaten van WISH en KB cellen, daarentegen zijn zeker gedeeltelijk van humane origine. Stroma cellen lijken op grond van deze bevindingen betrokken te zijn bij de productie en extracellulaire depositie van BM membraan componenten in epitheliale neoplasmata.

In hoofdstuk 4 wordt de depositie van BM op het grensvlak van tumor en stroma in 163 colorectale carcinomen besproken. De immunoreactiviteit werd semiquantitatief gescoord en ingedeeld in matig/sterk versus gering. Deze score werd gecorreleerd met de Dukes' stadia en overlevings data. De patienten groep met geringe BM depositie vertoonde een significant kortere overleving. Stratificatie wan de patienten met geringe versus matige/sterke BM depositie en Dukes' stadia A/B versus C/D, liet een significant kortere overleving zien van de groep patienten in Dukes' stadia $\mathrm{C} / \mathrm{D}$ met geringe BM depositie in vergelijking met de patienten in Dukes" stadia $\mathrm{C} / \mathrm{D}$ met matig/sterke BM depositie. Deze resultaten suggereren dat in de groep patienten in Dukes' stadium $C$, tumoren met een relatief sterk invasief en metastaserend vermogen kunnen worden onderscheiden van tumoren met een gering invasief en metastaserend vermogen.

In hoofdstuk 5 wordt de BM depositie op het grensvlak van tumor en stroma in 27 plaveiselcel carcinomen van de long bestudeerd. Weefselstukjes uit het centrum en de periferie van deze tumoren werden ingevroren, in formaline gefixeerd en in paraf- 
fine ingebed en er werden stukjes voor electronen microscopie bewerkt. Met antilichamen tegen collageen type IV en laminine werden de BM op licht microscopisch niveau gevisualiseerd met behulp van een indirecte immunoperoxidase techniek. De licht microscopische bevindingen werden vergeleken met de warnemingen op ultrastructureel niveau. De periferie van de tumoren vertoonde continue BM, in het patroon wan de preexistente alveolaire architectuur. Invasieve groei in de alveolaire septa werd in de periferie van de tumoren niet waargenomen. In tegenstelling hiermee, vertoonde het centrum van de tumoren een strek wisselende BM depositie, variërend van continu tot bijna totaal ontbrekend; een alveolair patroon was niet herkenbaar. Het stroma in het centrum van de tumor bevatte spoelvormige cellen met onregelmatige pericellulaire $\mathrm{BM}$, die ultrastructureel als myofibroblast konden worden geïdentificeerd. De licht en electronen microscopische bevindingen stemden grotendeels met elkaar overeen. Uit deze studie kan worden geconcludeerd dat in de periferie van plaveiselcel carcinomen in de long expansieve groei plaats vindt, en invasieve groei beperkt lijkt te blijven tot het centrum van de tumor.

Het patroon van BM depositie werd ook onderzocht in benigne en maligne nevomelanocytaire lesies zoals beschreven in hoofdstuk 6 . Om immunoreactiviteit te verkrijgen met antilichamen tegen BM componenten in paraffine coupes van archief materiaal was het noodzakelijk om behalve de gebruikelijke pepsine preincubatie de coupes ook met $6 \mathrm{M}$ guanidine- $\mathrm{HCl}$ te behandelen. $\mathrm{BM}$ depositie werd waargenomen rond individuele- en clusters nevo-melanocytaire cellen, die in contact zijn met het dermale bindweefsel. Tussen epidermale cellen en geheel intra-epidermaal gelegen nevo-melanocytaire cellen werd geen immunoreactiviteit tegen BM componenten waargenomen. Interactie van tumor cellen met stromale componenten is klaarblijkelijk vereist voor BM depositie in nevo-melanocytaire lesies. BM discontinuiiteit in de afwezigheid van ontstekings infiltraat wijst in geval van twijfel sterk in de richting van een maligne melanoma. Het algemene patroon van BM depositie is in benigne en maligne nevo-melanocytaire lesies gelijk en heeft derhalve geen betekenis in cle differentiële diagnostiek. Het aantonen van hyaline deposities, die immunoreactiviteit vertonen met antilichamen tegen $\mathrm{BM}$ componenten, $k$ an het onderscheid tussen juveniele en maligne melanomen ondersteunen. Het opsporen van angioinvasieve groei, een prognostische factor van betekenis, wordt aanzienlijk verbeterd door immunohistochemische aankleuring van BM. Pericellulaire BM depositie in metastasen van slecht gedifferentieercle tumoren, dient de aandacht te vestigen op de mogelijkheid van een maligne melanoma.

In hoofdstuk. 7 worden de resultaten van de studies besproken tegen de achtergrond van algemene aspecten van $B M$ in relatie tot invasieve groei van tumoren. Tot slot wordt een overzicht gegeven van het belang van de immunohistochemische detectie van $\mathrm{BM}$ voor de diagnostische histopathologie. 



\section{DANKWOORD}

Het onderzoek voor dit proefschrift werd uitgevoerd binnen het kader van het KWF project "Basement membranes in cancer" (project nr. RL 85-2), en werd grotendeels binnen de vakgroep pathologie verricht. Uit dit dankwoord zal blijken, dat wezenlijke bijdragen zijn geleverd door andere vakgroepen en ook door instituten buiten de Rijksuniversiteit Limburg.

Op de eerste plaats ben ik mijn promotor prof.dr. F.T. Bosman zeer erkentelijk. Beste Fré, met veel genoegen kijk ik terug op de periode, warin ik binnen het kader van het door jouw geinitieerde KWF project, het onderzoek voor dit proefschrift heb uitgevoerd. Niet alleen jouw kennis van zaken, maar ook jouw enthousiasme, was voor mij een grote stimulans en heeft veel respect afgedwongen. In de eindfase van mijn opleiding tot patholoog-anatoom heb ik bovendien met jouw opleiders kwaliteiten kennis mogen maken.

Ir. Jacques Cleutjens, Cor Beek en Monique Vallinga-Ummelen, met jullie heb ik het grootste deel van het onderzoek uitgevoerd. De werkzaamheden en de hiermee samenhangende discussies zijn altijd in een vriendschappelijke sfeer verlopen. Jullie bijdragen aan dit proefschrift zijn voor mij van doorslaggevende betekenis geweest. Ook prof.dr. Jan Willem Arends heeft een grote bijdrage geleverd, niet alleen inhoudelijk, maar ook door zijn voortdurende stimulerende houding.

Margriet Pijls en Birgit Kuypers-Engelen hebben nauwgezet een groot gedeelte van de immunohistochemische kleuringen verricht.

In de beginfase zijn dr. Ton de Goeij en Edith van der Linden sterk betrokken geweest bij dit onderzoek, in een latere fase heeft dr.ir. Kees Verstijnen met ons samengewerkt. Drs. Rop Simon, destijds als student-assistent aan de vakgroep pathologie verbonden, en drs. Helma van Zandvoort ben ik zeer erkentelijk voor hun inzet.

Claire Bollen-Prevot en Marianne Rikers-Laarmans verzorgden de manuscripten, die naar de vaktijdschriften werden gestuurd.

Buiten onze vakgroep wil ik $\mathrm{dr}$. Theo Wiggers, thans als chirurg verbonden aan de Daniël den Hoed Kliniek te Rotterdam, bedanken voor zijn bijdrage. Voor de statistische analyse zorgde dr. Lex Volovics. Marcia Steegmans-van Puyenbroek verwerkte de patienten gegevens in het onderzoek van de colorectale carcinomen.

Bij de fotografie heb ik veel steun gehad van de audiovisuele dienst van het Academisch Ziekenhuis Maastricht.

De samenwerking met dr. Koert Dingemans, verbonden aan het Academisch Medisch Centrum, Universiteit van Amsterdam, was voor een deel van dit proefschrift van groot belang, voor zijn bijdrage ben ik hem zeer erkentelijk. Ook dr. Sjoerd 
Wagenaar, patholoog-anatoom, St. Antonius Ziekenhuis Nieuwegein, dank ik voor zijn bijdrage. Verder wil ik Ella Vaarkamp en Felle Schmitz du Moulin, verbonden aan het St. Antonius Ziekenhuis Nieuwegein en Marius van den Bergh Weerman en Peter Teelling, verbonden aan het Academisch Medisch Centrum, voor hun bijdrage bedanken.

De kritische kanttekeningen en suggesties van de leden van de promotiecommissie bestaande uit: prof.dr. G. Kootstra, prof.dr. G. Blijham, prof.dr. J. Geraedts, prof.dr. M. Mareel en prof.dr. A. Martinez-Hernandez, hebben geleid tot inhoudelijke verbeteringen.

Dr. Frans Stassen wekte mijn interesse voor wetenschappelijk onderzoek tijdens een wetenschaps stage, die deel uitmaakte van de medische studie. Een vervolg hierop vormde mijn student-assistentschap bij dr. Frans Stassen, een periode waarin ik, mede door de samenwerking met Cor Beek, met vele basale onderzoekstechnieken kennis heb gemaakt. Door mijn contacten met prof.dr. Jan Willem Arends werd gedurende mijn student-assistentschap de interesse voor de klinische pathologie gewekt. In de eerste drie jaar van mijn opleiding tot patholoog-anatoom, een periode waarop ik met veel genoegen terugkijk, heeft prof.dr. G.J.V. Swaen een solide basis gelegd. In die tijd volgde hij enthousiast het begin van mijn onderzoek bij prof.dr. Fré Bosman.

Tot slot wil ik allen, die niet met naam vermeld worden, maar wel een bijdrage aan dit proefschrift geleverd hebben, wan harte bedanken.

De uitgave van dit proefschrift werd financieel ondersteund door de Stichting Bevordering Klinische Pathotogie Limburg en Euro-Diagnostic b.v. Apeldoorn. 


\section{CURRICULUM VITAE}

1950 Geboren te Kerkrade

1963-1968 HBS B, St. Antonius Doctor College, Kerkrade

1968-1969 Biologie, Katholieke Universiteit, Nijmegen

1969-1973 Fysiotherapie, Academie voor Fysiotherapie, Heerlen

1973-1975 Fysiotherapeut, Stichting Verpleeghuizen en Bejaardezorg Kerkrade, Revalidatie Centrum Hoensbroek

1975-1981 Geneeskunde, Rijks Universiteit Limburg

1981-1985 Assistent geneeskundige in opleiding tot patholoog-anatoom, Academisch Ziekenhuis Maastricht, opleiders prof.dr G.J.V. Swaen, prof.dr. F.T Bosman

1985- Patholoog-anatoom, universitair docent Rijksuniversiteit Limburg 